\title{
The Genesis of the Giant Shuangjianzishan Epithermal Ag-Pb-Zn Deposit, Inner Mongolia, NE China
}

\author{
Degao Zhai ${ }^{1}{ }^{2}$, Anthony E. Williams-Jones ${ }^{2}$, Jiajun Liu ${ }^{1}$, David Selby ${ }^{3,4}$, Panagiotis C. Voudouris ${ }^{5}$, \\ Stylianos Tombros ${ }^{6}$, Kuan $\mathrm{Li}^{1}$, Peilin $\mathrm{Li}^{1}$, Hongjun Sun ${ }^{7}$
}

${ }^{1}$ State Key Laboratory of Geological Processes and Mineral Resources, School of Earth Sciences and Resources, China University of Geosciences, Beijing, 100083, China

${ }^{2}$ Department of Earth and Planetary Sciences, McGill University, Quebec, 3450, Canada

${ }^{3}$ Department of Earth Sciences, Durham University, Durham, DH1 3LE, UK

${ }^{4}$ State Key Laboratory of Geological Processes and Mineral Resources, School of Earth Resources, China University of Geosciences, Wuhan, 430074, China

${ }^{5}$ Department of Mineralogy-Petrology, National and Kapodistrian University of Athens, 15784, Athens,

Greece

${ }^{6}$ Department of Geology, University of Patras, Rion, 26500, Greece

${ }^{7}$ Tiantong Mining Company, Chifeng, 024000, China

1

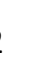

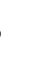

$$
\text { "E-mail: dgzhai@cugb.edu.cn }
$$

24

5




\section{Abstract}

The newly-discovered Shuangjianzishan Ag-Pb-Zn deposit with $145 \mathrm{Mt}$ of ore grading $128.5 \mathrm{~g} / \mathrm{t} \mathrm{Ag}$ (locally up to $32,000 \mathrm{~g} / \mathrm{t}$ ) and $2.2 \mathrm{wt} . \% \mathrm{~Pb}+\mathrm{Zn}$ is located in the Great Hinggan Range (GHR) Metallogenic Belt, NE China, and is currently the largest Ag deposit in Asia. The Ag-Pb-Zn orebodies occur as veins and are hosted primarily by a Permian slate. Recent drilling and core logging have identified a partially Mo-mineralized granite porphyry intrusion adjacent to the Ag-Pb-Zn mineralized veins. This wellpreserved magmatic-hydrothermal system therefore offers an excellent opportunity to evaluate the possible temporal and genetic relationship between Mo-mineralized porphyry intrusions and $\mathrm{Ag}-\mathrm{Pb}-\mathrm{Zn}$ veins. Three primary paragenetic stages of veining have been recognized: (I) early pyrite+quartz $\pm K-$ feldspar, (II) main ore sulfide+sulfosalt+quartz+calcite+sericite+chloritetepidote, and (III) post-ore quartz. The silver mineralization occurs mainly in the late paragenetic part of Stage II, in which canfieldite $\left(\mathrm{Ag}_{8} \mathrm{SnS}_{6}\right)$, argentite $\left(\mathrm{Ag}_{2} \mathrm{~S}\right)$ and freibergite $\left[(\mathrm{Ag}, \mathrm{Cu})_{12} \mathrm{Sb}_{4} \mathrm{~S}_{13}\right]$ are the dominant $\mathrm{Ag}$-bearing ore minerals. A combination of ore mineral chemical and sulfur isotope geothermometers and physicochemical calculations suggest that the $\mathrm{Ag}-\mathrm{Pb}-\mathrm{Zn}$ mineralization took place at a temperature of $250^{\circ}$ to $200^{\circ} \mathrm{C}$, a pH of 6.7 to 5.6 , and a $\Delta \log f \mathrm{O}_{2}(\mathrm{HM})$ of -2.4 to -8.7 .

A conspicuous enrichment of $\mathrm{Sn}$ and Se in the ore, which is represented by minerals containing the metal suite $\mathrm{Ag}-\mathrm{Pb}-\mathrm{Zn}$-(Cu-Sn-Se-Sb), likely reflects a close genetic association between the base metal mineralization and a magma. In situ analyses show that the $\delta^{34} \mathrm{~S}$ values of the sulfides and $\mathrm{Ag}$-bearing sulfosalts from the $\mathrm{Ag}-\mathrm{Pb}-\mathrm{Zn}$ mineralized veins vary from -4.67 to $+2.44 \%$; the mean value is $-2.11 \pm$ $1.49 \%$ o $(n=77)$. The calculated mean $\delta^{34} \mathrm{~S}_{\mathrm{H} 2 \mathrm{~S}}$ value of the ore-forming fluid is $-1.65 \pm 0.83 \%$, which is indicative of a magmatic sulfur source. In situ Pb isotope analyses of the ore minerals yielded a narrow range of values $\left({ }^{206} \mathrm{~Pb} /{ }^{204} \mathrm{~Pb}\right.$ of 18.243 to $18.310,{ }^{207} \mathrm{~Pb} /{ }^{204} \mathrm{~Pb}$ of 15.503 to 15.563 and ${ }^{208} \mathrm{~Pb} /{ }^{204} \mathrm{~Pb}$ of 38.053 to $38.203, n=59$ ). Comparisons to corresponding isotopic data for the various rock units in the area and sulfides from nearby ore deposits indicate that there were substantial contributions of $\mathrm{Pb}$, and other metals (e.g., Ag and Zn), to the Shuangjianzishan deposit from a Mesozoic granitic source.

Diorite-granodiorite dikes and dacite are crosscut by the $\mathrm{Ag}-\mathrm{Pb}-\mathrm{Zn}$ veins, and therefore, pre-date ore formation. These rock units have zircon U-Pb ages of $250.2 \pm 2.0$ and $133.9 \pm 1.4 \mathrm{Ma}$, respectively. A concealed, weakly Mo-mineralized granite porphyry intrusion proximal to the Ag-Pb-Zn mineralized vein system yielded zircon U-Pb ages of $134.4 \pm 1.0(M S W D=0.1)$ and $134.4 \pm 1.0 \mathrm{Ma}(\mathrm{MSWD}=0.2)$, for coarse- and fine-grained facies, respectively. These ages are indistinguishable within the uncertainty 
from the zircon ages for the dacite and a granite intrusion $\sim 2 \mathrm{~km}$ north of the mineralized veins, which has a weighted mean U-Pb zircon age of $135.2 \pm 1.4 \mathrm{Ma}(\mathrm{MSWD}=0.78)$. Molybdenite from three quartz vein/veinlet samples hosted by slate immediately above the porphyry intrusion yielded Re-Os model ages from $136.3 \pm 0.9$ to $133.7 \pm 1.2 \mathrm{Ma}$ and a weighted mean Re-Os age of $134.9 \pm 3.4 \mathrm{Ma}$. Finally, three pyrite samples separated from the Ag-Pb-Zn mineralized veins have a weighted mean Re-Os model age of $135.0 \pm 0.6 \mathrm{Ma}$. The very similar zircon U-Pb ages for the Mo mineralized granite porphyry and dacite, and Re-Os ages for molybdenite and pyrite in the Shuangjianzishan ore district indicate that the Mesozoic magmatic-hydrothermal activity was restricted to a relatively short time interval ( 136 to $133 \mathrm{Ma})$. They also suggest that the weakly Momineralized granite porphyry was likely the source of the fluids and metals that produced the $\mathrm{Ag}-\mathrm{Pb}$ Zn mineralization.

Based on our geological observations and an extensive analytical database, a model is proposed for the genesis of the giant Shuangjianzishan Ag-Pb-Zn deposit in which the ore-forming fluid and its metals (i.e., $\mathrm{Ag}, \mathrm{Pb}$, and $\mathrm{Zn}$ ) were exsolved during crystallization of the final phase of a composite granite porphyry intrusion. This fluid transported metals to the distal parts of the system, where they were deposited in pre-existing faults or fractures created by the withdrawal of magma during the waning stages of the magmatic-hydrothermal event. The present study of the Shuangjianzishan Ag-Pb-Zn deposit and those of other magmatic-hydrothermal ore deposits in the region provide compelling evidence that the widespread Mesozoic felsic magmatism and $\mathrm{Ag}-\mathrm{Pb}-\mathrm{Zn}$ mineralization in the southern GHR took place in an intracontinental extensional tectonic setting, which was synchronous with, and spatially associated to, Paleo-Pacific slab rollback and lithospheric delamination and thinning.

\section{Introduction}

Silver-lead-zinc vein-type mineralization has made a major contribution to the global supply of $\mathrm{Ag}$ and base metals. In addition, its close temporal, spatial and genetic association with porphyry-type mineralization has been long recognized and is well documented (e.g., Guilbert and Park, 1986; Einaudi et al., 2003; Sillitoe, 2010; Catchpole et al., 2015). Many studies of magmatic-hydrothermal systems have developed genetic models for porphyry ore systems (Einaudi et al., 2003; Heinrich, 2005; WilliamsJones and Heinrich, 2005; Seedorff et al., 2005; Rusk et al., 2008; Sillitoe, 2010; Richards, 2011; Wilkinson, 2013; Chiaradia, 2014). In contrast, much less attention has been paid to the Ag-Pb- $\mathrm{Zn}$ vein 
mineralization, which typically occurs peripheral to, adjacent to, or is superimposed on the mineralized porphyry systems (Seedorff et al., 2005; Sillitoe, 2010; Zhai et al., 2017; Rottier et al., 2018a). The close spatial-temporal relationship between porphyry Cu-Mo and Ag-Pb-Zn vein mineralization has provided a very useful guide for exploration that has led to the discovery of new Ag-Pb-Zn veins adjacent to porphyry Cu-Mo deposits and vice versa, e.g., the Butte ore district (Rusk et al., 2008). Some Ag-Pb-Zn vein deposits, however, do not appear to be genetically linked to porphyry intrusions and their genesis still remains controversial (Beaudoin and Sangster, 1992; Kissin and Mango, 2014).

Characteristic features of $\mathrm{Ag}-\mathrm{Pb}-\mathrm{Zn}$ vein-type deposits can be summarized as follows: (1) a common metal suite of $A g-P b-Z n-( \pm C u \pm A u \pm B i \pm S b \pm A s)$, (2) a sulfide-rich ore (commonly massive) composed of galena, sphalerite and a variety of Ag-bearing sulfosalts and a gangue of quartz and calcite, (3) the occurrence of the orebodies as epigenetic open-space filled veins spatially associated with sericitization and silicification, (4) in some cases, a well-developed metal and alteration zonation at the deposit scale, (5) deposition mostly under epithermal conditions from magmatic-hydrothermal fluids of low to moderate salinity (commonly $<10 \mathrm{wt} . \% \mathrm{NaCl}$ equivalent), and (6) structural control of the mineralization by late regional faults (e.g., Einaudi, 1981; Baumgartner et al., 2009; Bendezú and Fontboté, 2009; Fontboté and Bendezú, 2009; Kissin and Mango, 2014; Catchpole et al., 2015; Rottier et al., 2018a, b; Zhai et al., 2019a, and references therein). These polymetallic vein deposits, which historically have been an important source of $\mathrm{Zn}, \mathrm{Pb}$, and $\mathrm{Ag}$ in the North American Cordillera and in Peru, are also referred to as Cordilleran base metal deposits, Butte-type vein deposits, polymetallic veins, or zoned base metal veins (e.g., Einaudi, 1981; Guilbert and Park, 1986; Einaudi et al., 2003; Bendezú and Fontboté, 2002, 2009; Baumgartner et al., 2009; Fontboté and Bendezú, 2009; Catchpole et al., 2015; Rottier et al., 2016, and references therein).

The Great Hinggan Range (GHR) Metallogenic Belt, NE China, hosts a number of porphyry Mo-(Cu), skarn Fe-(Sn), epithermal Au-Ag, and Ag-Pb-Zn vein deposits (e.g., Zeng et al., 2011; Ouyang et al., 2014; Mao et al., 2014; Zhai et al., 2014a, b, 2018a, 2019b; Shu et al., 2016; Chen, Y., et al., 2017). In particular, it contains more than $30 \mathrm{Ag}-\mathrm{Pb}-\mathrm{Zn}$ ore deposits with total resources of $>57,000 \mathrm{t}$ of silver (Zhai et al., 2017), making it the largest silver province in China. The Ag-Pb-Zn vein-type deposits are particularly common in the southern segment of the GHR, where recent discoveries include the Shuangjianzishan, Bianjiadayuan, Bairendaba, and Weilasituo deposits (e.g., Ouyang et al., 2014; Liu, C., et al., 2016; Liu, Y., et al., 2016; Zhai et al., 2017). Among them, the largest is the Shuangjianzishan deposit with reserves 
exceeding $145 \mathrm{Mt}$ of ore at an average grade of $128.5 \mathrm{~g} / \mathrm{t} \mathrm{Ag}(\approx 18,630$ tons $\mathrm{Ag})$ and $2.2 \mathrm{wt} . \% \mathrm{~Pb}+\mathrm{Zn}$ (Kuang et al., 2014), making this deposit the largest Ag deposit in Asia. It also has an extremely high Ag grade, which locally exceeds $32,000 \mathrm{~g} / \mathrm{t}$.

Recently, a concealed, weakly Mo-mineralized granite porphyry intrusion was intersected in drill holes adjacent to the Shuangjianzishan $\mathrm{Ag}-\mathrm{Pb}-\mathrm{Zn}$ veins. Whether-or-not the $\mathrm{Ag}-\mathrm{Pb}-\mathrm{Zn}$ vein mineralization is related to this newly-discovered porphyry intrusion has been unclear, and resolving this issue is important for exploration in the area. Several studies of the Shuangjianzishan deposit, mostly published in Chinese or reported in student dissertations, have addressed the ore deposit geology (Kuang et al., 2014), mineralogy (Wu et al., 2014; Zhai et al., 2018b), whole rock geochemistry (Liu, C., et al., 2016; Gu et al., 2017), magmatic rock and ore geochronology (Wu et al., 2013; Wang et al., 2016; Ouyang et al., 2016; Liu, C., et al., 2016; Wang, F., 2017; Zhang, 2018), and S-Pb isotope geochemistry (Wang, 2015; Jiang, B., et al., 2017; Wang, X., 2017). However, questions related to the sulfur and metal source, the timing of mineralization, and the genesis of the deposit remain unresolved and greatly debated. For example, there is no consensus on the age of ore formation. Wu et al. (2013) proposed a mineralization age of $132.7 \pm 3.9 \mathrm{Ma}$ using the sphalerite $\mathrm{Rb}-\mathrm{Sr}$ method, whereas Wang et al. (2016) obtained ages for alteration and mineralization of $146.9 \pm 1.9$ and $162.6 \pm 2.6$ Ma using sericite Ar-Ar and molybdenite Re-Os methods, respectively. Wang, F. (2017) subsequently obtained an age of $159 \pm 6 \mathrm{Ma}$ by applying the Re-Os method to arsenopyrite and pyrite, and $148 \pm 1 \mathrm{Ma}$ using the U-Pb method (hydrothermal zircon). Finally, Gu et al. (2017) obtained a zircon U-Pb age for the Momineralized granite porphyry of $133.4 \pm 1.2 \mathrm{Ma}$, which they proposed was associated with the Ag-PbZn mineralization.

In this contribution, we present the results of a comprehensive investigation of the Shuangjianzishan Ag-Pb-Zn deposit, utilizing ore mineralogical, textural, petrochemical, sulfide Re-Os and zircon U-Pb geochronological, and in situ $\mathrm{S}$ and $\mathrm{Pb}$ isotopic data. Our new data are used to constrain the source and nature of the hydrothermal fluid, the metal source, and the timing of ore mineral deposition, and to determine its genetic relationship to the porphyry intrusion. The results of this study show that the Ag$\mathrm{Pb}-\mathrm{Zn}$ veins are part of a magmatic-hydrothermal system related to a nearby Mo-mineralized granite porphyry and reflect the relatively high solubility of the metals (e.g., $\mathrm{Ag}, \mathrm{Pb}$, and $\mathrm{Zn}$ ), which facilitated their transport to the distal parts of the system, where they were deposited in pre-exiting faults or fractures created by magma withdrawal during the waning stages of magmatic-hydrothermal activity. 


\section{Regional Geology}

The Shuangjianzishan Ag-Pb-Zn deposit is located in the Great Hinggan Range (GHR) Metallogenic Belt, which lies in the easternmost segment of the Central Asian Orogenic Belt (CAOB) (Fig. 1A). The

CAOB evolved through complex closure of the Paleo-Asian Ocean from the Neoproterozoic to the late Permian (Wilde, 2015), which separated the Siberian craton in the north from the Tarim and North China cratons in the south (Fig. 1A). It formed via successive accretion of arc complexes, accompanied by the emplacement of immense volumes of granitic magma (Jahn et al., 2000), and is believed to have been the world's largest site of juvenile crust formation in the Phanerozoic era (Jahn, 2004). This region records complex processes involving tectonic events that marked the transition in the late PermianEarly Triassic from the dominantly NE-SW directed motion of the Paleo-Asian plate to the E-W directed motion of the Paleo-Pacific plate (e.g., Li, 2006; Wilde, 2015; Zhou et al., 2018, and references therein). closure of the Paleo-Asian Ocean was completed in the late Permian ( 260 Ma); (ii) a switch in geodynamic setting took place in the late Permian-Early Triassic ( $260-250 \mathrm{Ma})$ that is reflected by the Paleo-Asian Ocean closure and the onset of tectonism associated with subduction of the Paleo-Pacific plate; (iii) events associated with the westward advance of the Paleo-Pacific plate in the Early Jurassicearly Cretaceous ( 250-140 Ma); and (iv) the slab rollback of the Paleo-Pacific plate after the early Cretaceous ( $140 \mathrm{Ma}$ ), which created an extensional setting associated with thinning and delamination of the lithosphere (e.g., Li, 2006; Wang et al., 2006; Zhang et al., 2010; Wu et al., 2011; Wilde, 2015; Liu, K., et al., 2017; Zhou et al., 2018, and references therein). The region underwent widespread Mesozoic volcanic and intrusive activity (Fig. 1B), including emplacement of I- and A-type granitoids at different stages (i.e., Early to Late Triassic and late Jurassic to early Cretaceous) of the geotectonic evolution (Xiao et al., 2004; Wu et al., 2005, 2011), which today underlie $>50 \%$ of the surface area in the mountainous regions (HBGMR, 1993). Compared with other areas in the CAOB, NE China was strongly affected by Paleo-Pacific subduction and, as a result, is one of the most metallogenically important areas of the eastern Asian Mesozoic continental margin (Wu et al., 2011). (Sn), and Ag-Pb-Zn vein deposits (Fig. 1C; Ouyang et al., 2014; Shu et al., 2016; Chen, Y., et al., 2017; granites (Fig. 1C), the latter of which were produced during regional Mesozoic magmatism (Mao et al., 

the region (Fig. 1C), as shown by discovery of the Shuangjianzishan, Bianjiadayuan, Bairendaba and Weilasituo deposits (e.g., Ouyang et al., 2014; Liu, Y., et al., 2016; Wang et al., 2017; Zhai et al., 2018d), which define the southern segment of the GHR that is the most important Ag-Pb-Zn metallogenic belt in northern China.

Available geochronological data indicate that magmatic-hydrothermal deposits in this area formed during two distinct metallogenic events, namely, an early event in the Permian and Triassic ( 290 to 230 Ma; Zhou et al., 2014; Duan et al., 2015; Jiang, S., et al., 2017) and a late event in the Jurassic and Cretaceous ( 160 to $130 \mathrm{Ma}$; Zeng et al., 2015; Ouyang et al., 2015; Liu, Y., et al., 2016; Wang et al., 2017; Jiang, S., et al., 2017). Numerous age determinations of porphyry Mo-(Cu) and skarn Fe-(Sn) deposits suggest that the magmatic-hydrothermal systems developed mainly during the second metallogenic event (Fig. 1C), synchronously with granite emplacement (Mao et al., 2014; Ouyang et al., 2015; Shu et al., 2016; Zhai et al., 2017; Gao et al., 2018). However, reliable ages for the vein-type Ag$\mathrm{Pb}-\mathrm{Zn}$ mineralization are generally lacking, mostly because these deposits have received much less study, and more importantly, because of the paucity of minerals that can be easily and accurately dated. However, the ages of some of these deposits have been estimated reliably where it has been possible to establish a close genetic association between the porphyry and polymetallic vein-type mineralization (e.g., the Bianjiadayuan and Weilasituo deposits; Zhai et al., 2017; Wang et al., 2017).

\section{Ore Deposit Geology}

The main rock-types exposed in the Shuangjianzishan ore district are late Permian slates, Mesozoic volcanic rocks and Quaternary gravel (Fig. 2A). The Permian slates are part of the Dashizhai Formation, and form $>30 \%$ of the surface outcrop in the mine area (Fig. 2A). The slates are $>950 \mathrm{~m}$ thick, and generally strike NE and dip NW at 55-65. They are the main host to the ores (Fig. 2A, B). The volcanic rocks are located mainly to the southeast of the Ag-Pb-Zn mineralized zones, unconformably overlie the slates (Fig. 2A) and are interpreted to have been emplaced in the Jurassic (Wu et al., 2014). They belong mainly to the Xinmin Formation, and consist largely of dacite lava and rhyolitic tuff with a thickness of $>200 \mathrm{~m}$; some of the Ag-Pb-Zn mineralized veins crosscut these rock units (Fig. 2A). Quaternary 

Shuangjianzishan ore deposit (Fig. 2A). An unexposed granite porphyry intrusion was intersected in the core of drill hole ZK12-37 from a depth of $516 \mathrm{~m}$ to the bottom of the hole at $1080 \mathrm{~m}$. This intrusion is located approximately $800 \mathrm{~m}$ to the northwest of the main mineralized veins (Fig. 2A). Texturally, the porphyry has been subdivided into a lower coarse-grained facies and an upper fine-grained facies that intrudes the coarse-grained facies and is observed to a depth of $846 \mathrm{~m}$ (Fig. 3A). The fine-grained facies shows evidence of having undergone strong potassic and silicic alteration, and contains numerous quartz-molybdenite veins ( 0.1 to $2 \mathrm{~cm}$ width). Numerous K-feldspar-quartz veinlets/stockworks and less abundant magmatic-hydrothermal breccias cemented by minor Mo mineralization also occur in the fine-grained porphyry (Fig. 3A). In contrast, the coarse-grained facies is only altered near its contact with the fine-grained facies and is unalterd at depth and free of quartz-molybdenite veins. The overlying slates have been sericitized and silicified for $\sim 150 \mathrm{~m}$ above the fine-grained porphyry and locally contain molybdenite-quartz \pm albite veins/veinlets and zones of hydrothermal brecciation (Fig. 3A). On the basis of the above observations, we speculate that the fine-grained porphyry may be genetically related to the $\mathrm{Ag}-\mathrm{Pb}-\mathrm{Zn}$ mineralization considered in this paper. In addition to the granitic pluton and granite porphyry, there are diorite and granodiorite dikes that strike NW or NE, dip $60^{\circ}$ to the $\mathrm{SE}$, vary in width from 1 to $8 \mathrm{~m}$, and have been traced along strike for distances of 50 to $300 \mathrm{~m}$. Several of these dikes are crosscut by the Ag- $\mathrm{Pb}-\mathrm{Zn}$ mineralized veins (Figs. 2A and $3 \mathrm{~B}$ ), indicating that they were intruded prior to the mineralization.

The major faults in the district have NW-, NE- and NS-strikes. However, most Shuangjianzishan Ag-PbZn veins were emplaced parallel to a NW-striking fault zone (Fig. 2A). This fault zone varies in width from 500 to $800 \mathrm{~m}$, strikes $300-310^{\circ}$, dips NE at 55 to $65^{\circ}$ and has been traced for a distance of $>5000 \mathrm{~m}$. These faults are characterized by extensional shear features. A few veins were emplaced in a NE-striking fault zone (Fig. $2 \mathrm{~A}$ ), which strikes $30-50^{\circ}$ and dips SE at $60^{\circ}$. Minor veins are also hosted by the NSstriking fault zones (Fig. 2A). The NW- and NE-striking faults are observed to have been truncated by some of the Ag-Pb-Zn-barren NS-striking faults.

The Shuangjianzishan Ag-Pb-Zn deposit was discovered in 2013 and has been mined since that time. More than 70 major veins and numerous stockworks and disseminations have been identified, all of which are hosted by the Permian slate. According to a 2018 exploration report (Zhang, 2018), the deposit has a total resource of $145 \mathrm{Mt}$ of ore containing $>18.6 \mathrm{Kt}$ of $\mathrm{Ag}$ with an average grade of 128.5 

zones $4.7 \mathrm{~km}$ apart, namely Shuangjianzishan in the west and Xinglongshan in the east, have been identified (Kuang et al., 2014). The bulk of the economic mineralization, however, is in the eastern ore zone (Fig. 2A). Although several oxidized veins are exposed in slate outcrops (Fig. 4A), most of the mineralized veins are not exposed (Fig. 4B-D). Mineralized veins fill fractures that strike $\sim 310^{\circ}$ and dip SW at $50-60^{\circ}$, whereas they are sparse in the NE- and near NS-striking fault zones. The orebodies comprise sets of parallel veins concentrated in zones ranging from 2 to $10 \mathrm{~m}$ in width, although locally these zones range up to $30 \mathrm{~m}$ in width; individual veins range up to $10 \mathrm{~m}$ in width (Fig. 4B, C). They (the orebodies) generally have strike lengths of between 100 and 800 m, and extend vertically 500 m (Fig. (Fig. 4B) or in structural domains associated with faults having orientations different from those controlling the major veins. by an assemblage of sericite, chlorite, quartz, and calcite. This alteration is concentrated in halos that are distributed symmetrically on the two sides of the mineralized veins (Fig. 4B, C). In addition, the slates have experienced silicification and subordinate weaker potassic alteration (secondary K-feldspar), which predated the main sulfide mineralization. This alteration is associated with euhedral pyrite, or locally pyrite-quartz veins. The latter are consistently cut by the main mineralized veins (Fig. 4D). The alteration associated with the Ag-Pb-Zn veins (Fig. 4D-G) includes a sub-assemblage of quartz-sericite \pm chlorite that was closely related to $\mathrm{Ag}$ mineral deposition (Fig. 4E), particularly the very high grade and massive ores (Fig. 4E, F). The final stage of alteration is represented by quartz, which occurs as narrow veins (1$5 \mathrm{~mm}$ width) cutting the Ag-Pb-Zn mineralized veins (Fig. 4D).

\section{Sampling and analytical methods}

\section{Ore mineral textures and compositions}

More than ninety samples were collected from different mining levels and drill holes from the Shuangjianzishan deposit and more than 120 polished thin sections were examined in reflected and transmitted light. A Zeiss Supra 55 Sapphire field emission scanning electron microscope (FESEM) coupled with an Oxford energy-dispersive X-ray spectrometer (EDS), located at the China University of 
quantitatively and imaging textural relationships among them. Element line scanning was undertaken for $\mathrm{Ag} L \alpha, \mathrm{Sb} L \alpha, \mathrm{Pb} M \alpha, \mathrm{Fe} K \alpha, \mathrm{Cu} K \alpha$, Se $K \alpha$, and $\mathrm{S} K \alpha$ using an accelerating voltage of $20 \mathrm{kV}$ and a working distance of $15 \mathrm{~mm}$. An in-lens detector for secondary electron imaging was used to characterize topographic features, and an AsB detector was used to visualize compositional differences among the minerals (backscattered electron images). Samples were coated with an $\sim 10 \mathrm{~nm}$ thick platinum film for electric conduction before analysis.

The compositions of the sulfides and sulfosalts were determined using a JEOL 8230 Superprobe equipped with wavelength- and energy-dispersive $\mathrm{X}$-ray detectors and a back-scatter electron detector at the Microprobe Center, Chinese Academy of Geological Sciences (CAGS). The accelerating voltage was $20 \mathrm{kV}$. The beam current and counting times for the major elements were $20 \mathrm{nA}$ and $20 \mathrm{~s}$, respectively (10 s for background measurement), and the beam diameter was $1 \mu \mathrm{m}$. Natural and synthetic mineral standards of chalcopyrite, sphalerite, galena, pyrrhotite, InAs and native $\mathrm{Ag}, \mathrm{Sb}, \mathrm{Se}$, Sn were utilized for calibration. The X-ray lines measured were $\mathrm{Ag} L \alpha, \mathrm{Sb} L \alpha, \mathrm{As} L \alpha, \mathrm{Pb} L \alpha, \mathrm{Zn} L \alpha, \mathrm{Sn} L \alpha$, Fe $\mathrm{K} \alpha, \mathrm{Cu} K \alpha$, Se K $\alpha$, and S K $\alpha$. X-ray element mapping was performed using the energy-dispersive X-ray detector. The dwell time was set to $20 \mu$ s to provide the highest possible resolution.

\section{Whole rock geochemistry}

Eleven rock samples collected from drill cores and underground tunnels in the Shuangjianzishan ore district were analyzed for their whole rock compositions. The samples comprise fine-grained granite porphyry (4), coarse-grained granite porphyry (3), diorite-granodiorite dikes (2), granite (1) and dacite (1). Powders of the samples were prepared by crushing with corundum plates and grinding in an agate disk mill at the Hebei Geological Survey, China. Major element concentrations were analyzed by ICPOES, and trace element concentrations by ICP-MS (Agilent-7500a) at CUGB. The precision for the major elements, as determined by the reproducibility of laboratory standards and duplicates, was better than $1 \%$, with the exception of $\mathrm{TiO}_{2}(\sim 1.5 \%)$ and $\mathrm{P}_{2} \mathrm{O}_{5}(\sim 2.0 \%)$, and for minor and trace elements was better than $10 \%$. The results of the analyses are reported in Table 1 . Most of the samples analyzed in this study are relatively fresh and have low loss on ignition (LOI; $\leq 1.5 \mathrm{wt} . \%)$, except for the two diorite dikes and the dacite, both of which were altered.

\section{In situ $\mathrm{S}$ and $\mathrm{Pb}$ isotopes}

Fifteen samples were collected for in situ sulfur and lead isotope analysis from several mining levels and drill cores, and are representative of the variety of mineralization in the Ag- $\mathrm{Pb}-\mathrm{Zn}$ veins. Prior to 
analysis, the thin sections were carefully observed with an optical microscope and FESEM, and analyzed compositions. Sulfur and lead isotopes were analyzed using a femtosecond laser ablation coupled multicollector inductively coupled plasma mass spectrometer (fSLA-MC-ICP-MS) at the State Key Laboratory of Continental Dynamics, Northwest University, China. Details of the analytical methods for $\mathrm{S}$ and $\mathrm{Pb}$ isotopes have been reported by Chen, L., et al. (2017) and Yuan et al. (2015), respectively. These analyses were supplemented by analyses carried out using a $266 \mathrm{~nm}$ NWR UP Femto, femtosecond (fs) laser ablation system (ESI, U.S.A.) coupled to Nu Plasma 1700 (NP-1700) and Nu Plasma II (NP-II) MCICP-MS (Nu Instruments, Wrexham, U.K.), respectively. The surfaces of the polished thin sections were cleaned with milli-Q water $(18.2 \mathrm{M} \Omega \cdot \mathrm{cm})$. Argon flow rates and voltage were adjusted to give the best signal stability and intensity. Each sample acquisition consisted of background collection for $30 \mathrm{~s}$, followed by ablation signal collection for $70 \mathrm{~s}$, and a wash time of $50 \mathrm{~s}$ to reduce memory effects. The analyses employed a relatively low laser energy (the fluence ranged from 0.5 to $3.5 \mathrm{~J} \mathrm{~cm}^{-2}$ ), a $10 \mathrm{~Hz}$ frequency and an ablation rate of $2 \mu \mathrm{m} / \mathrm{s}$. The spot size for sulfur and lead were 20-37 and 9-40 $\mu \mathrm{m}$, respectively. Instrument drift and mass bias were corrected using a sample-standard bracketing approach with repeated measurement of the standard before and after each sample. The international standard, NBS123 (sphalerite) and internal standards of PY-4 (pyrite), CBI-3 (galena), PSPT-3 (sphalerite), CPY-1 (chalcopyrite), and IAEA-S-1 ( $\mathrm{Ag}_{2} \mathrm{~S}$ ) were used for calibration in the sulfur isotope analyses. The analytical precision calculated from replicate analyses of unknown samples is better than $0.2 \%$ o $(1 \sigma)$. The measured $\delta^{34}$ SVCDT value of $17.8 \pm 0.3 \%$ o $(n=156)$ for standard NBS123 is consistent with the reported value of $17.4 \pm 0.2 \%$ (Craddock et al., 2008). The TI NIST SRM $997\left(20 \mathrm{ppb},{ }^{205} \mathrm{TI} /{ }^{203} \mathrm{TI}=2.38890\right)$ and NIST SRM 610 glass were used as internal and external $\mathrm{Pb}$ isotope standards, respectively. Repeated analyses of the NIST SRM 610 glass standard yielded highly reliable and reproducible results with mean ${ }^{206} \mathrm{~Pb} /{ }^{204} \mathrm{~Pb},{ }^{207} \mathrm{~Pb} /{ }^{204} \mathrm{~Pb}$, and ${ }^{208} \mathrm{~Pb} /{ }^{204} \mathrm{~Pb}$ ratios of $17.050 \pm$ $0.004,15.510 \pm 0.002$, and $36.985 \pm 0.006(1 \sigma, n=63)$, respectively, which are very close to the reported reference ratios (Stern and Amelin, 2003).

\section{Zircon U-Pb dating}

Five rock samples were selected for zircon U-Pb dating. These comprise granite porphyry (fine- and coarse-grained) (Fig. 3A), granite intrusion ( $2 \mathrm{~km}$ north of the vein system), diorite dike and dacite (Fig. 3B). Zircon crystals from the selected samples were separated by standard heavy-liquid and magnetic techniques, followed by hand-picking under a binocular microscope. Prior to LA-ICP-MS analysis, the 

age determinations were carried out using a LA-ICP-MS in the State Key Laboratory of Geological Processes and Mineral Resources at CUGB. The crystals were ablated using an excimer laser ablation system (UP193SS). An Agilent 7500a ICP-MS instrument was used to acquire ion-signal intensities. A laser spot size of $36 \mu \mathrm{m}$, laser energy density of $8.5 \mathrm{~J} / \mathrm{cm}^{2}$ and a repetition rate of $10 \mathrm{~Hz}$ were applied during analysis. Helium and argon were used as the carrier and make-up gases, and were mixed via a T-connector before entering the ICP-MS. Uranium, Th and Pb concentrations were calibrated by using ${ }^{207} \mathrm{~Pb} /{ }^{235} \mathrm{U}$ and ${ }^{208} \mathrm{~Pb} /{ }^{232} \mathrm{Th}$ ratios were calculated using the GLITTER 4.4.1 software and corrected for both instrumental mass bias and depth-dependent elemental and isotopic fractionation using Harvard zircon 91500 as the external standard (Wiedenbeck et al., 1995). The zircon standard, TEMORA, was used as a secondary standard to monitor the deviation of the age measurement/calculation (Black et al., 2003). The Harvard zircon 91500 and TEMORA zircon standards yielded weighted mean ages of $1062.5 \pm 0.5$ and $418.0 \pm 6.9 \mathrm{Ma}$, respectively, which are very similar to the reported ages (i.e., 1065 and $417 \mathrm{Ma}$; Wiedenbeck et al., 1995; Black et al., 2003). Isoplot 3.0 was used to calculate the U-Pb ages and to make the Concordia plots (Ludwig, 2003).

\section{Molybdenite and pyrite Re-Os dating}

Three molybdenite-quartz veins/veinlets $(0.5-2 \mathrm{~cm})$ in the altered slate above the granite porphyry were analyzed for their molybdenite Re-Os isotope ratios (Fig. 3A). To date, no molybdenite has been found in the Ag-Pb-Zn mineralized veins. The grain size of the molybdenite typically ranges from 0.1 to $0.3 \mathrm{~mm}$ (Fig. 3A). The Re-Os ratios of four pyrite separates from the main Ag-Pb-Zn veins sampled at depths of 240 to $410 \mathrm{~m}$ were also analyzed (Fig. 3B). The pyrite grain-size ranges from 3 to $5 \mathrm{~mm}$. The mineral separates of both the molybdenite and pyrite samples were obtained using conventional methods (i.e., crushing, washing, sieving, magnetic separation, and heavy liquid separation) followed by hand picking under a binocular microscope.

The rhenium-osmium analyses were carried out at the Laboratory for Sulfide and Source Rock Geochronology and Geochemistry at Durham University, United Kingdom. For molybdenite, a weighed aliquot ( 21 to $61 \mathrm{mg}$ ) of the mineral separate plus a known amount of spike solution $\left({ }^{185} \mathrm{Re}+\right.$ isotopically normal Os) were loaded into a Carius tube with $11 \mathrm{~N} \mathrm{HCl}(1 \mathrm{ml})$ and $15.5 \mathrm{~N} \mathrm{HNO}_{3}(3 \mathrm{ml})$, sealed, and digested at $220^{\circ} \mathrm{C}$ for $\sim 24 \mathrm{~h}$. For pyrite, $\sim 0.4 \mathrm{~g}$ of sample, together with a mixed spike of 
${ }^{185} \mathrm{Re}+{ }^{190} \mathrm{Os}$, were loaded into a Carius tube with $11 \mathrm{~N} \mathrm{HCl}(3 \mathrm{ml})$ and $15.5 \mathrm{~N} \mathrm{HNO} 3(6 \mathrm{ml})$, sealed, and digested at $220^{\circ} \mathrm{C}$ for $\sim 24 \mathrm{~h}$. For both sample types, Os was purified from the acid medium using solvent extraction $\left(\mathrm{CHCl}_{3}\right)$ at room temperature and microdistillation methods. The Re fraction was purified by $\mathrm{NaOH}$-solvent extraction and anion chromatography. The Re and Os isotopic compositions were measured by negative thermal ionization mass spectrometry (N-TIMS) using a Thermo Scientific TRITON mass spectrometer; the Re and Os isotope compositions were measured using the static Faraday collection mode for molybdenite, and SEM in peak hopping mode for the pyrite Os fraction. All Re-Os uncertainties are reported at the $2 \sigma$ absolute level, which followed the propagation of uncertainties related to Re and Os mass spectrometer measurements, blank determinations, spike and standard isotopic compositions, and calibration uncertainties of ${ }^{185} \mathrm{Re}$ and ${ }^{187} \mathrm{Os}$. During the analyses, the Re and Os blanks were $<2.5$ and $0.1 \mathrm{pg}$, respectively, and the ${ }^{187} \mathrm{Os} /{ }^{188} \mathrm{Os}$ ratio of the blank was $0.22 \pm 0.02$. Results of analyses of the Henderson molybdenite reference material (RM8599 $-27.695 \pm 0.038 \mathrm{Ma}$ ) provided by Li et al. (2017) overlapped with those of this study. A ${ }^{187}$ Re decay constant of $1.666 \times 10^{-11} y$ ${ }^{1}$ with an uncertainty of $0.31 \%$ was used in the calculation of the Re-Os dates (Smoliar et al., 1996; Selby et al., 2007).

\section{Results}

\section{Ore mineralogy and paragenesis}

Crosscutting relationships involving the different types of veins and textural relationships among the ore and gangue minerals show that the $\mathrm{Ag}-\mathrm{Pb}-\mathrm{Zn}$ mineralization at Shuangjianzishan occurred in three discrete stages (Fig. 4C, D): an early pyrite+quartz \pm K-feldspar stage (I), a sulfide+sulfosalt+quartz+calcite+sericite+chlorite \pm epidote stage (the main ore stage II) and a late quartz stage (III) (Fig. 5). The quartz-pyrite \pm K-feldspar assemblage occurs mainly in thin veins/veinlets ( 2 to $10 \mathrm{~mm}$ in width) accompanied by potassic alteration halos (K-feldspar), and pyrite less commonly occurs as disseminations in the silicified slate. Pyrite in these veins/veinlets is relatively coarse-grained $(\sim 0.1$ $\mathrm{mm}$ in diameter) and euhedral, occurring either as cubes or pyritohedra. The early veins/veinlets were crosscut, replaced or included as fragments in the main ore stage veins (Fig. 4C), in which sphalerite, galena, pyrite, quartz and calcite are the main minerals and are accompanied by subordinate proportions of Ag-bearing minerals and chalcopyrite. The main ore stage has been further subdivided into substages II-1 and II-2 (Fig. 5). Substage II-1 is represented by the ore mineral assemblage of galena+sphalerite+pyrite+chalcopyrite \pm canfieldite \pm freibergite and an alteration/gangue assemblage of 
quartz+calcite+chlorite \pm epidote \pm sericite. This substage corresponded to a period of abundant sulfide do not contain any silver (Electronic Appendix Table A1), indicating that silver mineralization was very limited in the early Substage II-1.

The main Ag stage was Substage II-2, which is represented by Ag-bearing sulfosalts and argentite \pm galena \pm sphalerite \pm chalcopyrite and an alteration/gangue assemblage of quartz+sericite \pm calcite \pm chlorite (Fig. 5). Although we have subdivided the main ore stage into two substages, it is noteworthy that both substages can be observed in the same veins, suggesting that they belong to a single continuous stage (Fig. 5). Chemically, the paragenesis for the mineralization corresponds to an evolution from Fe-S through Pb-Zn-Fe-Cu-S to Ag-Cu-Sn-Sb-Se-S (Fig. 5). canfieldite $\left(\mathrm{Ag}_{8} \mathrm{SnS}_{6}\right)$, argentite $\left(\mathrm{Ag}_{2} \mathrm{~S}\right)$, freibergite $\left[(\mathrm{Ag}, \mathrm{Cu})_{10}(\mathrm{Fe}, \mathrm{Zn})_{2} \mathrm{Sb}_{4} \mathrm{~S}_{13}\right]$, polybasite ( $\left.\mathrm{Ag}_{9} \mathrm{CuS}_{4} \mathrm{Ag}_{4} \mathrm{Cu}_{2} \mathrm{Sb}_{1.25} \mathrm{As}_{0.75} \mathrm{~S}_{7}\right)$, pyrargyrite $\left(\mathrm{Ag}_{3} \mathrm{SbS}_{3}\right)$, and stephanite $\left(\mathrm{Ag}_{5} \mathrm{SbS}_{4}\right)$. Minor native silver and electrum also have been observed (Wu et al., 2014). The other minor sulfides in this substage generally do not contain $\mathrm{Ag}$, except for galena, which may contain up to $7 \mathrm{wt} . \% \mathrm{Ag}$ but more typically contains $<0.5$ wt.\% Ag. making up $>80$ vol.\% of the Ag budget based on petrographic observations. Canfieldite is usually associated with argentite and freibergite, both of which commonly are associated with the earlier sulfides (e.g., sphalerite and galena) along their crystal boundaries (Fig. 6A-D), or occur interstitially to base metal sulfides (e.g., sphalerite and chalcopyrite; Fig. 6A, B), showing that these Ag-bearing minerals formed late relative to the base metal sulfides. Canfieldite has $\mathrm{Ag}$, $\mathrm{Sn}$, and $\mathrm{S}$ contents that range from 59.7 to $69.4,9.5$ to 19.3 , and 10.6 to $21.3 \mathrm{wt} . \%$, respectively (Electronic Appendix Table A1). The selenium content varies from below the detection limit (0.01 wt.\%) to $11.6 \mathrm{wt} . \%$ (Zhai et al., 2018b), and is heterogeneously distributed within individual crystals (Fig. 7). Canfieldite is the only mineral that contains significant $\mathrm{Se}$. There are also minor to trace amounts of $\mathrm{Cu}$, Fe, and Te.

417 Argentite commonly replaced Stage II-1 sulfides, mainly sphalerite, galena (Fig. 6A), and chalcopyrite 418 (Fig. 6B), and is intergrown with sericite and quartz; larger grains ( $>100 \mu \mathrm{m})$ commonly enclose the base metal sulfides (e.g., chalcopyrite and galena; Fig. 6E). Argentite also occurs in fine veinlets (20 to $50 \mu \mathrm{m}$ wide) that crosscut argentian galena (Fig. 6F). The Ag content of the argentite ranges from 71.8 to 84.5 
wt.\%. There are also minor proportions of $\mathrm{Sb}$ and $\mathrm{As}$, and in some cases Se. Freibergite, which as noted above, is commonly associated with canfieldite (Fig. 6C, D), is intergrown with or replaced base metal sulfides, particularly galena (Fig. 6F-H). It occurs both as large grains (e.g., $>200 \mu \mathrm{m}$ ) and small cuspateshaped irregular inclusions in galena (Fig. 6F, G); these galena-hosted inclusions also include pyrargyrite and minor pyrrhotite (Fig. 6G). The Ag, Cu and Sb contents of the freibergite vary from 19.4 to $42.1 \mathrm{wt} . \%$, 11.9 to 25.1 wt.\% and 19.3 to 25.8 wt.\%, respectively, which span the compositional range from argentian tetrahedrite to freibergite. There are also significant concentrations of Fe (1.0 to 5.1 wt.\%) and $\mathrm{Zn}$ ( 0.6 to $4.3 \mathrm{wt} . \%)$. The tennantite component is small ( 0.8 to $1.4 \mathrm{wt} . \% \mathrm{As}$ ). Among the remaining Ag minerals, pyrargyrite is the most important phase and commonly occurs as intergrowths with galena and in rare cases traces with pyrrhotite (Fig. 6G). Lesser proportions of stephanite and polybasite occur as intergrowths with freibergite and replaced galena and sphalerite (Fig. $6 \mathrm{H}, \mathrm{I})$.

\section{Lithogeochemistry}

Compositionally, the granite and granite porphyry are very similar and plot in the subalkaline granite field on a TAS discrimination diagram (Electronic Appendix Fig. A1). In chemical affinity, the porphyry varies from metaluminous to peraluminous (Electronic Appendix Fig. A2F), and belongs to the high-K calc-alkaline family (Electronic Appendix Fig. A2E). The fine-grained granite porphyry has the highest $\mathrm{SiO}_{2}$ content among all the analyzed samples (mostly due to the silicic alteration), i.e., from 75.7 to 80.0 wt.\%, whereas the $\mathrm{SiO}_{2}$ content of the coarse-grained granite porphyry varies from 69.6 to $70.0 \mathrm{wt} . \%$. Both the fine- and coarse-grained granite porphyry samples have similarly high $\mathrm{K}_{2} \mathrm{O}$ contents, from 4.0 to 4.9 wt.\%, whereas the $\mathrm{Na}_{2} \mathrm{O}$ content of the coarse-grained porphyry is considerably higher

441 (4.1 to 4.6 wt.\%) than that of the fine-grained porphyry (2.2 to 3.7 wt.\%). The $\mathrm{K}_{2} \mathrm{O}$ content for both facies increases and the $\mathrm{Al}_{2} \mathrm{O}_{3}, \mathrm{CaO}, \mathrm{MgO}, \mathrm{FeO}^{\top}, \mathrm{TiO}_{2}$ and $\mathrm{P}_{2} \mathrm{O}_{5}$ contents decrease with increasing $\mathrm{SiO}_{2}$ content (Electronic Appendix Fig. A2A-E), as is the case for subalkaline granite suites globally (Whalen et al., 1987). The dacite sample has a relatively low silica content $\left(65.0 \mathrm{wt} . \% \mathrm{SiO}_{2}\right)$, and the two samples of diorite to granodiorite dikes also have low but variable silica contents ( 54.2 and $67.3 \mathrm{wt} . \% \mathrm{SiO}_{2}$ ), due wt.\%; Table 1). and $\mathrm{La} / \mathrm{Yb}(<20)$ values, low Sr (mostly $<300 \mathrm{ppm}$ ), $\mathrm{Rb}$ (mostly <300 ppm) and $\mathrm{Nb}$ (mostly $<20 \mathrm{ppm}$ ) contents, and high $\mathrm{Y}$ contents (mostly $>30 \mathrm{ppm}$ ) (Table 1). They also have chondrite-normalized profiles 
that display moderate enrichment of the light REE and negative Eu anomalies $\left(E u_{n} / E u^{*}<0.7\right)(E l e c t r o n i c$ Appendix Fig. A3A); the average $[\mathrm{La} / \mathrm{Yb}]_{N}$ is $7.0 \pm 3.4(n=21)$. The fine-grained porphyry, however, has a more negative $\mathrm{Eu}$ anomaly $\left(\mathrm{Eu}_{n} / \mathrm{Eu}^{*}<0.2\right)$ than the coarse-grained facies $\left(\mathrm{Eu}_{n} / \mathrm{Eu}^{*}>0.3\right)$. Both porphyry facies are relatively depleted in $\mathrm{Ba}, \mathrm{Nb}, \mathrm{Sr}, \mathrm{P}, \mathrm{Eu}$, and $\mathrm{Ti}$, and enriched in $\mathrm{U}, \mathrm{La}$, and $\mathrm{Nd}$ relative to primitive mantle (Electronic Appendix Fig. A3B).

\section{In situ $\mathrm{S}$ and $\mathrm{Pb}$ isotope compositions}

The range of $\delta^{34} \mathrm{~S}$ values for all the sulfides and sulfosalts is relatively restricted, from -4.67 to $+2.44 \%$ o (Figs. 8, 9A) and largely independent of the depth in the deposit from which the samples were taken. Moreover, those for sphalerite $($ mean $=-1.41 \%)$, pyrite $($ mean $=-1.27 \%$ ), chalcopyrite $($ mean $=-1.58 \%)$ and arsenopyrite $($ mean $=-1.34 \% \circ)$ are comparable to the values for freibergite $($ mean $=-1.17 \% \circ)$ and canfieldite $\left(\right.$ mean $=-1.54 \%$ ) $($ Table 2$)$. The $\delta^{34} \mathrm{~S}$ values for galena $($ mean $=-3.58 \%$ ), however, are somewhat lower (Fig. 9A, B) and those for pyrargyrite are significantly higher (mean $=+2.0 \%$ ). The $\delta^{34} \mathrm{~S}$ values decrease in the order of pyrite $>$ sphalerite $>$ chalcopyrite $>$ galena based on the analyses of a given assemblage in the same ore stage, which is consistent with the experimentally determined equilibrium sulfur isotope fractionation factors for ${ }^{32} \mathrm{~S}$ and ${ }^{34} \mathrm{~S}$ between the fluid and sulfide minerals (Seal, 2006, and references therein) and likely indicates contemporaneous deposition of these sulfides from the ore fluid.

Interestingly, there is a small but significant variation in the sulfur isotopic composition within single crystals of most of the sulfides and sulfosalts. For example, the $\delta^{34} S$ value of the galena crystal shown in Figure $8 \mathrm{~A}$ varies from -4.51 to $-3.11 \%$ and for the crystal shown in Figure $8 \mathrm{~B}$ varies from -3.79 to $3.22 \%$. The variation in the $\delta^{34} \mathrm{~S}$ values within the freibergite grains is somewhat smaller; for example, it is -1.72 to $-1.35 \%$ for the grain shown in Figure $8 \mathrm{C}$. In contrast, the variation is larger $(+1.41$ to $+2.44 \%$ ) for pyrargyrite, as shown by the data for the grain in Figure 8D.

All the sulfides and sulfosalts analyzed have very similar lead isotope values (Fig. 10A, B; Table 3). The ${ }^{206} \mathrm{~Pb} /{ }^{204} \mathrm{~Pb},{ }^{207} \mathrm{~Pb} /{ }^{204} \mathrm{~Pb}$ and ${ }^{208} \mathrm{~Pb} /{ }^{204} \mathrm{~Pb}$ ratios range from 18.243 to $18.310,15.503$ to 15.563 , and 38.053 to 38.203 , and the mean ratios are $18.279,15.537$ and 38.143 , respectively (Table 3 ). These ratios do not vary significantly with the mineral or its depth in the deposit. The ${ }^{206} \mathrm{~Pb} /{ }^{204} \mathrm{~Pb}$ ratio varies linearly with the ${ }^{207} \mathrm{~Pb} /{ }^{204} \mathrm{~Pb}$ ratio (Fig. $10 \mathrm{~A}$ ) and with the ${ }^{208} \mathrm{~Pb} /{ }^{204} \mathrm{~Pb}$ ratio (Fig. 10B); the $\mathrm{R}^{2}$ values are 0.877 and 0.786 , respectively.

\section{Zircon U-Pb ages}



age of $250.2 \pm 2.0 \mathrm{Ma}(\mathrm{N}=19, \mathrm{MSWD}=0.3$; Fig. $11 \mathrm{~A})$, showing that it was emplaced in the Early Triassic. This age is indistinguishable, within the uncertainty, from those reported previously for similar diorite dikes using the same methodology, i.e., $254 \pm 3$ to $249 \pm 2 \mathrm{Ma}$ (Cui, 2015; Liu, C., et al., 2016). The dacite, which was cut by several Ag-Pb-Zn mineralized quartz veins (Figs. 2A and 3B), yielded a mean zircon ${ }^{206} \mathrm{~Pb} /{ }^{238} \mathrm{U}$ age of $133.9 \pm 1.4 \mathrm{Ma}(\mathrm{N}=22, \mathrm{MSWD}=0.43$; Fig. $11 \mathrm{~B})$ and thus formed in the early Cretaceous instead of the Jurassic, as previously assumed (Wu et al., 2014). The granite in the northern part of the district $(\sim 2 \mathrm{~km}$; Fig. $2 \mathrm{~A})$ yielded a mean zircon ${ }^{206} \mathrm{~Pb} /{ }^{238} \mathrm{U}$ age of $135.2 \pm 1.4 \mathrm{Ma}(\mathrm{N}=20, \mathrm{MSWD}=0.06 ;$ Fig. $11 \mathrm{C})$, which is indistinguishable within the uncertainty from that previously reported $(133.7 \pm 0.6 \mathrm{Ma}$; $\mathrm{Wu}, 2014)$. Identical zircon ages of $134.4 \pm 1.0(\mathrm{~N}=$ $21, \mathrm{MSWD}=0.1 ;$ Fig. 11D $)$ and $134.4 \pm 1.0 \mathrm{Ma}(\mathrm{N}=21, \mathrm{MSWD}=0.2$; Fig. 11E) were obtained for the coarse- and fine-grained granite porphyry, respectively. These zircon ${ }^{206} \mathrm{~Pb} /{ }^{238} \mathrm{U}$ ages are very similar 494 to those reported by Zhang (2018) of $134.4 \pm 1.7$ and $135.9 \pm 1.1 \mathrm{Ma}$ for samples from the drill hole (ZK12-37) considered in the current study, and are very similar to the zircon ${ }^{206} \mathrm{~Pb} /{ }^{238} \mathrm{U}$ age of another concealed granite porphyry (133.4 $\pm 1.2 \mathrm{Ma}$; Gu et al., 2017) intersected in drill hole ZK12-50 3 km east of the vein system.

\section{Molybdenite and pyrite Re-Os ages}

The Re concentrations of the three molybdenite samples range from 0.12 to $2.61 \mathrm{ppm}$ and the measured ${ }^{187} \mathrm{Re}$ and ${ }^{187} \mathrm{Os}$ values range from 0.07 to $1.66 \mathrm{ppm}$ and 0.17 to $3.77 \mathrm{ppb}$, respectively 501 (Table 4). The model ages for these samples are comparable, varying from $136.3 \pm 0.9$ to $133.7 \pm 1.2$ Ma; the weighted mean age is $134.9 \pm 3.4 \mathrm{Ma}(\mathrm{MSWD}=9$; Table 4). These ages are, within the 503 uncertainty, identical to the zircon ${ }^{206} \mathrm{~Pb} /{ }^{238} \mathrm{U}$ ages of the porphyry and the other granitic intrusions in the district.

The Re and Os concentrations in the four pyrite samples range from 0.26 to $1.08 \mathrm{ppb}$ and from 1.45 to $13.08 \mathrm{ppt}$ (Table 5), and the ${ }^{187} \mathrm{Re} /{ }^{188} \mathrm{Os}$ and ${ }^{187} \mathrm{Os} /{ }^{188} \mathrm{Os}$ values from 496.9 to 34959.9 and 2.8 to 69, respectively (Table 5). Two of the samples yielded very high ${ }^{187} \mathrm{Re} /{ }^{188} \mathrm{O}$ s values $(15 \mathrm{SJ}-16=\sim 6300$; $15 \mathrm{SJ}-114=\sim 35000)$, indicating that the Os fraction is dominated by radiogenic ${ }^{187} \mathrm{Os}\left({ }^{187} \mathrm{Os}^{r}\right)$ (Stein et al., 2000). Unfortunately, the Re-Os data did not return a meaningful isochron age for any of the pyrite samples. We interpret this to have been due to the highly variable initial ${ }^{187} \mathrm{Os} /{ }^{188} \mathrm{Os}$ ratio of the 
samples, which may reflect multiple sources of Os (e.g., the porphyry and the host slates). Model Re-

Os dates for three of the four pyrite separates, calculated using initial ${ }^{187} \mathrm{Os} /{ }^{188} \mathrm{O}$ s values varying from $\sim 1.1$ to 6.2 , yielded a weighted mean age of $135.0 \pm 0.6 \mathrm{Ma}(\mathrm{MSWD}=9)$.

\section{Temperature of ore deposition}

The temperature of ore deposition at Shuangjianzishan was estimated using a combination of ore mineral chemistry and stable isotope geothermometry. A temperature for the silver mineralization was estimated using the composition of freibergite and the fahlore geothermometer of Sack (2005), which was developed using an internally consistent thermodynamic database for the system $\mathrm{Ag}_{2} \mathrm{~S}-\mathrm{Cu}_{2} \mathrm{~S}-\mathrm{ZnS}-$ $\mathrm{FeS}-\mathrm{Sb}_{2} \mathrm{~S}_{3}-\mathrm{As}_{2} \mathrm{~S}_{3}$. This geothermometer makes use of isotherms based on molar ratios of $\mathrm{Ag} /(\mathrm{Ag}+\mathrm{Cu})$ and $\mathrm{Zn} /(\mathrm{Zn}+\mathrm{Fe})$ in fahlore. Freibergite crystals, which show no evidence of having undergone postmineralization solid-state reaction and exsolution (Zhai et al., 2019a), were selected for fahlore geothermometry. In addition, application of the fahlore geothermometer was restricted to freibergite crystals with $\mathrm{Ag} /(\mathrm{Ag}+\mathrm{Cu})$ molar ratios $<0.55$ because of the close spacing of the isotherms at higher ratios and the resulting high uncertainty of the corresponding temperature estimates. The temperatures estimated using this geothermometer ranged from $200^{\circ}$ to $280^{\circ} \mathrm{C}$ and the mean temperature was $\sim 240^{\circ} \mathrm{C}(\mathrm{n}=9$, Fig. 12$)$.

The mineral pairs sphalerite-galena, pyrite-galena, pyrite-sphalerite, pyrite-chalcopyrite, chalcopyrite-galena and sphalerite-chalcopyrite were used to estimate temperature based on the fractionation of ${ }^{32} \mathrm{~S}$ and ${ }^{34} \mathrm{~S}$ between these sulfide minerals and the equations of Seal (2006). Only mineral pairs that were in apparent textural equilibrium were used. These mineral pairs $(n=19)$ yielded temperatures from $142^{\circ}$ to $>570^{\circ} \mathrm{C}$. The highest temperatures were for pairs involving pyrite, a paragenetically early mineral. If these pairs are excluded, the range of temperature estimates using sulfur isotope geothermometry is from $210^{\circ}$ and $320^{\circ} \mathrm{C}$ (Electronic Appendix Fig. A4) and the mean temperature is $\sim 250^{\circ} \mathrm{C}$.

In summary, the sulfur isotope and fahlore chemical geothermometers yielded temperatures ranging from $210^{\circ}$ to $320^{\circ} \mathrm{C}$ (mean $\sim 250^{\circ} \mathrm{C}$ ) and $200^{\circ}$ to $280^{\circ} \mathrm{C}$ (mean $\sim 240^{\circ} \mathrm{C}$ ) for the base metal and silver mineralization, respectively, suggesting that base metal sulfides and Ag-bearing sulfosalts precipitated from an intermediate- to low-temperature hydrothermal fluid. These temperatures are similar to the homogenization temperatures of fluid inclusions hosted in quartz reported by Wang, X. (2017), which 
are from $170^{\circ}$ to $260^{\circ} \mathrm{C}$ for the base metal sulfide and silver mineralization.

\section{Unusual features of the mineralogy}

An unusual feature of the Shuangjianzishan deposit is that canfieldite $\left(\mathrm{Ag}_{8} \mathrm{SnS}_{6}\right)$ is one of the main silver minerals (Fig. 6A-D). Significantly, the canfieldite has an unusually high Se content (up to $11.6 \mathrm{wt} . \%$; Zhai et al., 2018b), which is zonally distributed such that the highest concentration is in the cores of crystals (Fig. 7D). Another unusual feature of the mineralogy is the occurrence of cassiterite (Fig. 7A, E; see also Jiang et al., 2018), which was replaced by canfieldite, argentite, galena and sphalerite (Fig. 7A). The element suite of the ore minerals of the Shuangjianzishan deposit therefore differs from that of the Ag-Pb-Zn veins associated with porphyry deposits in the North and South American Cordillera (e.g., Peru), which does not include significant Sn or Se (Bendezú and Fontboté, 2009).

We interpret the enrichment of Sn and Se in the Shuangjianzishan deposit to be of magmatic origin (as we do for the other ore elements; see below). In support of this interpretation, we note that $\mathrm{Sn}$ - and Se-bearing ore minerals also have been reported from several Ag-Au-Cu-Se-Te epithermal deposits that are spatially associated with porphyry deposits (e.g., the Prasolovskoye deposit, Kuril Islands, So et al., 1995; the Kawazu deposit, Japan, Shimizu et al., 2008; the Svetloye deposit, Russia, Alderton and Brameld, 2006; and the Mavrokoryfi prospect, Greece, Voudouris, 2011). It is also noteworthy that Se has been observed in the structure of molybdenite in intrusion-related deposits in Bohemia (Pasava et al., 2016), indicating a magmatic origin for the Se in these deposits. Finally, we note that a number of magmatic-hydrothermal ore deposits located relatively close to the Shuangjianzishan deposit, for example, the Bianjiadayuan Ag-Pb-Zn deposit, the Weilasituo Cu-Zn deposit, the Huanggangliang Fe-(Sn) deposit, the Dajing Cu-Sn deposit, the Baiyinnuoer Pb-Zn deposit, the Haobugao Fe-Zn deposit, and the Anle Cu-Sn deposit (Fig. 1C), are spatially associated with Sn-rich granitic intrusions/porphyries and may be genetically related to them (Ouyang et al., 2015; Zhu et al., 2016; Zeng et al., 2016; Zhai et al., 2017).

\section{Sulfur and metal sources}

The sulfides and sulfosalts from the Ag-Pb-Zn mineralized veins at Shuangjianzishan have a narrow range of $\delta^{34} S$ values (i.e., -4.67 to $+2.44 \%$ ) and an average value that is close to zero (Fig. 9A). Moreover, these values are independent of the mineral paragenesis (Fig. 9A) and the depth from which the samples were taken (Fig. 9B; Table 2). The corresponding range and mean $\delta^{34} \mathrm{~S}_{\mathrm{H} 2 \mathrm{~S}}$ values are -3.32 to $+0.77 \%$ and $-1.65 \pm 0.83 \%$, respectively, assuming a temperature of $250^{\circ} \mathrm{C}$. These observations suggest a magmatic source for the sulfur (Seal, 2006). The $\delta^{34} S$ values reported here are also very similar to 
those of sulfides in nearby magmatic-hydrothermal ore deposits (e.g., the Bianjiadayuan Ag-Pb-Zn, Weilasituo Zn-Cu-Ag, Baiyinnuoer Pb-Zn, Hashitu Mo, Haobugao Fe-Zn, and Huanggangliang Fe-Sn deposits), which are generally in the range -4 to $+4 \%$ (Yao et al., 2012; Ouyang et al., 2014; Zhai et al., 2014b, 2018c, 2019a, and references therein). This suggests strongly that most of the ore deposits in the southern GHR had a similar source of sulfur, namely a magma. Finally, we note that the relatively small range in the $\delta^{34} \mathrm{~S}$ values of the Shuangjianzishan ores, the even smaller range for individual minerals (Fig. 9) and the very small intra-crystal variation of these values indicate that $\mathrm{pH}$ and particularly $\mathrm{fO}_{2}$ did not vary significantly during ore formation (see Ohmoto, 1972; Wood, 1998; King et al., 2014).

In order to evaluate the source of the metals, we compared the lead isotope compositions of the sulfides and Ag-bearing sulfosalts from Shuangjianzishan with corresponding data for Mesozoic granite, andesite and basalt, Paleozoic granite, and Permian slate, as well as $\mathrm{Pb}$ isotope data for sulfides from numerous nearby magmatic-hydrothermal ore deposits (Electronic Appendix Table A3; Zhang et al., 1995, 2008; Shen and Fu, 1999; Chu et al., 2001; Cai et al., 2004; Wang, 2009; Zeng et al., 2009; Guo et al., 2010; Jiang et al., 2010; Shao et al., 2010; Yao et al., 2012; Wu et al., 2012; Zhai et al., 2014b, 2018c, 2019a). The ${ }^{206} \mathrm{~Pb} /{ }^{204} \mathrm{~Pb},{ }^{207} \mathrm{~Pb} /{ }^{204} \mathrm{~Pb}$, and ${ }^{208} \mathrm{~Pb} /{ }^{204} \mathrm{~Pb}$ ratios for the Shuangjianzishan ore minerals are very similar to those of magmatic-hydrothermal ore deposits in the region (Fig. 13A, B), suggesting strongly that the Shuangjianzishan ores and these deposits shared a common source for their metals. It should be noted, however, that the ranges for our ratios, which were obtained by in situ analysis, are significantly smaller than for the other deposits. We attribute this to the fact that the latter data were obtained from mineral separates. The ranges for our $\mathrm{Pb}$ isotope ratios are also narrower than those for the Shuangjianzishan deposit reported by Wang, F. (2017) from mineral separates; the latter ratios also indicate more radiogenic $\mathrm{Pb}$ isotope compositions (Electronic Appendix Fig. A5). We consider it likely that this difference is due to contamination of the separates by minerals with radiogenic $\mathrm{Pb}$ (e.g., sericite and K-feldspar).

The $\mathrm{Pb}$ isotopic ratios of the Shuangjianzishan ore minerals closely match those of the local Mesozoic (late Jurassic to early Cretaceous) granites (Fig. 13A, B). This suggests that the Pb and other metals (e.g., $\mathrm{Ag}$ and $\mathrm{Zn}$ ) originated mainly from Mesozoic magmas (e.g., the Mo-mineralized porphyry). In contrast, the substantial differences between the $\mathrm{Pb}$ isotopic ratios of the Shuangjianzishan ore minerals and those of the other rock units in the district, for example, the Mesozoic basalt, andesite, the Paleozoic 

ore metal budget.

603

604

\section{$\mathrm{pH}$ and $\mathrm{fO}_{2}$ conditions}

The $\mathrm{pH}-\log \mathrm{fO}_{2}$ conditions of ore formation and alteration were evaluated from phase equilibria calculated using the HCh software package (Shvarov, 2011). Stability relationships among the minerals were determined assuming that the minerals are all ideal solid solutions. The total dissolved sulfur concentration ( $(\Sigma S)$ was conservatively assumed to be $0.01 \mathrm{~m}$ (e.g., Bonsall et al., 2011; Williams-Jones and Migdisov, 2014), the $\delta^{34} S_{\Sigma S}$ was assumed to be $+0.5 \%$ (i.e., the isotopic composition of magmatic sulfur species), and the total dissolved $\mathrm{CO}_{2}(\Sigma \mathrm{C})$ was assumed to be $1 \mathrm{~m}$ (e.g., Ohmoto, 1972). The temperatures evaluated were $250^{\circ}$ and $200^{\circ} \mathrm{C}$ (see earlier discussion of the temperature of ore formation).

The $\mathrm{pH}$ of base metal sulfide and Ag-sulfosalt deposition at $250^{\circ} \mathrm{C}$ varied from 5.6 to 6.7 (pure water at this temperature has a $\mathrm{pH}$ value of 5.6) (Fig. 14A), based on the observation that this mineralization was associated with sericitization (Fig. 6A, I) and the occurrence of calcite as a gangue mineral (Fig. 4C). The presence of calcite also restricts $\log \mathrm{fO}_{2}$ to values above -43.1 and that of pyrite to values below 32.5 (Fig. 14A). The measured $\delta^{34} \mathrm{~S}$ values calculated to have been in equilibrium with the fluid for different sets of $\mathrm{pH}$ and $\log \mathrm{fO}_{2}$ conditions ( $\delta^{34} \mathrm{~S}=-4.67$ to $+2.44 \%$; Fig. $9 \mathrm{~A}$ ) further restricts $\log \mathrm{fO}_{2}$ to values below -36.8 (Fig. 14A). These values correspond to $\Delta \operatorname{logfO}_{2}(\mathrm{HM})$ values (hematite/magnetite buffer) of -8.7 to -2.4 . At $200^{\circ} \mathrm{C}$, the $\mathrm{pH}$ of base metal sulfide and Ag-sulfosalt deposition would have been 5.3 to 6.8 (the $\mathrm{pH}$ value of pure water at this temperature is 5.6) and the $\Delta \log \mathrm{fO}_{2}(\mathrm{HM})$ values would have been -8.5 to -2.2 (Fig. $14 \mathrm{~B}$ ). Thus, the $\mathrm{fO}_{2}$ conditions of $\mathrm{Ag}-\mathrm{Pb}-\mathrm{Zn}$ ore deposition varied from moderately to strongly reducing; the $\mathrm{pH}$ was nearly neutral to weakly alkaline.

\section{Timing of $\mathrm{Ag}-\mathrm{Pb}-\mathrm{Zn}$ mineralization}

The age of vein-type Ag-Pb-Zn mineralization in the GHR is still poorly constrained, whereas that of spatially-associated porphyry Mo-Cu and skarn Fe-Sn deposits is well-known from numerous molybdenite Re-Os dates. Although there have been many determinations of the age of $\mathrm{Ag}-\mathrm{Pb}-\mathrm{Zn}$ mineralization in the Shuangjianzishan deposit, there is no agreement on this age. For example, Cui (2015) proposed an age of $249.1 \pm 1.9 \mathrm{Ma}$ for the deposit based on a zircon $\mathrm{U}-\mathrm{Pb}$ age for one of the diorite dikes. As discussed earlier, however, these dikes predate the mineralization (Figs. 2A and 3B). Ouyang et al. (2016) proposed an age of $159.3 \pm 2.3 \mathrm{Ma}$ based on a zircon U-Pb date for a granite 

age of inclusions of a mineral such as muscovite that would have hosted the Rb and Sr. Wang et al. (2016) dated the mineralization indirectly by determining the age of sericite using the Ar-Ar method and obtained an age of $146.9 \pm 1.9 \mathrm{Ma}$, but they did not establish the spatial and temporal relationships between the sericite and the mineralization. They also reported a Re-Os age of $162.6 \pm 2.6 \mathrm{Ma}$ for molybdenite from the nearby granite porphyry described earlier in this paper. More recently, Wang, F. (2017) obtained an age of $159 \pm 6 \mathrm{Ma}$ for the Ag-Pb-Zn mineralization using the Re-Os method applied to arsenopyrite and pyrite, and a U-Pb age of $148 \pm 1$ Ma for hydrothermal zircon. establish the age of the mineralization. The results of our determinations of the ages of the different lithological units in the Shuangjianzishan district are illustrated in Figure 15A. A diorite dike that is crosscut by the Ag-Pb-Zn veins and is pre-ore (Fig. 15B) yielded a zircon U-Pb age of $250.2 \pm 2.0 \mathrm{Ma}$ (Fig. 11A). Dacite located in the southwestern part of the district (Fig. 2A), which is cut by several Ag-PbZn mineralized veins (Figs. 2A and 3B) and thus is also pre-ore, was dated at $133.9 \pm 1.4 \mathrm{Ma}$ (zircon $\mathrm{U}-\mathrm{Pb}$ method, $\mathrm{N}=22, \mathrm{MSWD}=0.43 ; \mathrm{Fig} .11 \mathrm{~B})$. Within the analytical uncertainty, the same age, 134.4 $\pm 1.0 \mathrm{Ma}$ (Fig. 11D, E), was obtained for a Mo-mineralized granite porphyry located only $800 \mathrm{~m}$ from the deposit using the zircon U-Pb method, suggesting that the dacite and porphyry may have been derived from the same magma (Fig. 15C). Their similar trace element compositions also support this hypothesis (Electronic Appendix Fig. A3). Moreover, Re-Os dating of molybdenite related to the porphyry yielded a weighted mean age of $134.9 \pm 3.4 \mathrm{Ma}(\mathrm{MSWD}=9$ ), which is indistinguishable within error from the age of the porphyry. Finally, a granite intrusion in the northern part of the mining district ( $2 \mathrm{~km}$ from the deposit) yielded a mean ${ }^{206} \mathrm{~Pb} /{ }^{238} \mathrm{U}$ age of $135.2 \pm 1.4 \mathrm{Ma}$, which is indistinguishable within the uncertainty from the $133.7 \pm 0.6 \mathrm{Ma}$ age reported by $\mathrm{Wu}$ (2014) for the same intrusion. 
661 (2013). These ages, within the error, are the same as the ages reported for the granite porphyry and its molybdenite mineralization (Fig. 15D). Based on these age determinations, we conclude that the Ag$\mathrm{Pb}-\mathrm{Zn}$ mineralization of the Shuangjianzishan deposit was the product of hydrothermal fluids released during an early Cretaceous felsic magmatic event at $\sim 134$ Ma (Fig. 15A). This event produced volcanic rocks (i.e., dacite) and granitic intrusions (Fig. 15C, D), including the nearby Mo-mineralized porphyry, which we speculate is genetically related to the $\mathrm{Ag}-\mathrm{Pb}-\mathrm{Zn}$ mineralization.

The age interpreted for the Shuangjianzishan deposit is similar to that for many other magmatichydrothermal ore deposits in the southern GHR (Fig. 1C). These include the Baiyinnuoer skarn Pb-Zn deposit (135 \pm 1 Ma, molybdenite Re-Os; Ouyang et al., 2015), the Huanggangliang skarn Fe-(Sn) deposit (135 \pm 2 Ma, molybdenite Re-Os; Zhai et al., 2014b), the Weilasituo greisen Sn and Cu-Zn vein deposit (136 $\pm 1 \mathrm{Ma}$, zircon U-Pb; Zhai et al., 2016), the Bairendaba Ag-Pb-Zn vein deposit (135 \pm 3 Ma, sericite Ar-Ar; Chang and Lai, 2010), the Anle Sn-(Cu) vein deposit (133 $\pm 3 \mathrm{Ma}$, sericite Ar-Ar; Wang et al., 2001), and the Dajing $\mathrm{Cu}$-(Sn) vein deposit (133 $\pm 1 \mathrm{Ma}$, zircon U-Pb/sericite Ar-Ar; Ishiyama et al., 2008; Jiang et al., 2012). Shuangjianzishan is thus a representative of an important late Mesozoic (early Cretaceous) metallogenetic event in the southern GHR that involved felsic magmatism (Mao et al., 2005, 2014; Wu et al., 2011; Ouyang et al., 2015; Zhai et al., 2015; Shu et al., 2016; Chen, Y., et al., 2017).

\section{Tectonic controls on $\mathrm{Ag}-\mathrm{Pb}-\mathrm{Zn}$ mineralization}

The regional magmatism in the early Cretaceous is represented by both I-type (granodiorite, monzogranite and syenite) and A-type granitoids (Wu et al., 2002); the latter are interpreted to have formed from magmas derived from the lower crust (Wei et al., 2008). These granitoids display an eastward-younging trend, which indicates their emplacement in an extensional setting (Zhang et al., 2010; Wu et al., 2011). The granite porphyry in the Shuangjianzishan district has a geochemical signature characteristic of an arc-related magma (i.e., $\mathrm{Y}>30 \mathrm{ppm}$ and $\mathrm{Sr} / \mathrm{Y}$ ratios $<10$; Electronic Appendix Fig. A6A), but nonetheless one that is distinguishable from the adakites, which are commonly

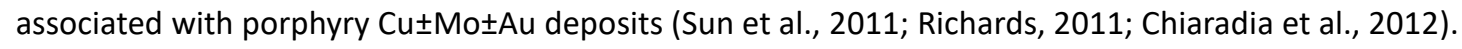
However, it also has characteristics typical of A-type granites forming in extensional tectonic settings (Electronic Appendix Fig. A6B). This setting for the GHR in the early Cretaceous is manifested by the development of extensional basins (e.g., the Songliao, Erlian, and Hailaer basins; Meng, 2003), formation of metamorphic core complexes (Wang et al., 2012), widespread alkali plutonism and 
volcanism (A-type granites and bimodal volcanic rocks; Wu et al., 2002; Wang et al., 2006; Zhang et al., 2010), and formation of Climax-type porphyry molybdenum deposits (e.g., the Hashitu, Haisugou, Banlashan, and Aolunhua deposits; Zhai et al., 2018c) and alkaline intrusion-related rare metal deposits (e.g., the Baerzhe Zr, REE and Nb deposit; Ouyang et al., 2015). It has been proposed that Paleo-Pacific subduction in the early Cretaceous caused lithospheric delamination, slab rollback and crustal extension of the back-arc domain (Zhang et al., 2010; Wu et al., 2011, and references therein). The slab rollback could have triggered large scale upwelling of the asthenosphere and back-arc spreading along the entire margin of NE China, softening the lithosphere, thereby facilitating the lithospheric thinning and extension observed across the East Asian continental margin for the early Cretaceous ( $\sim 140-110 \mathrm{Ma}$; Zhang et al., 2011). This, in turn, could have led to the emplacement of the large numbers of Cretaceous granitoids in NE China (Zhang et al., 2008; Wu et al., 2011; Wilde, 2015). In summary, we propose that the widespread synchronous $\mathrm{Ag}-\mathrm{Pb}-\mathrm{Zn}$ mineralization observed in the $\mathrm{GHR}$, including the Shuangjianzishan deposit, was a direct consequence of Paleo-Pacific subduction and subsequent slab rollback, lithospheric delamination, thinning and extension that triggered the emplacement of large volumes of granitic magma during the early Cretaceous.

\section{A Proposed Genetic Model}

The data presented in this paper provide strong evidence that the Ag-Pb-Zn veins of the Shuangjianzishan deposit were the product of a magmatic-hydrothermal system related to a nearby early Cretaceous Mo-mineralized granite porphyry. These data show, moreover, that the mineralization was coeval with the intrusion of this porphyry. In Figure 15, we present a model that explains the genesis of the Shuangjianzishan Ag-Pb-Zn deposit using the geological observations and geochemical data presented earlier. In this model, both the ore-forming fluid and metals (i.e., $\mathrm{Ag}, \mathrm{Pb}$, and $\mathrm{Zn}$ ) were sourced from the adjacent porphyry intrusion, which has an arc affinity (Electronic Appendix Fig. A6) and was emplaced in the early Cretaceous (Fig. 15A) in response to regional slab rollback and lithospheric delamination and thinning. The porphyry was intruded in two phases (early coarse-grained and late fine-grained phases), the second of which exsolved a magmatic-hydrothermal fluid. The metals and sulfur were transported to well beyond the confines of the intrusion ( $800 \mathrm{~m}$ away) by this fluid, where they were deposited in pre-existing faults or fractures created by the withdrawal of magma during the waning stages of the magmatic-hydrothermal system (Fig. 15D).

The Shuangjianzishan ore district is similar in many aspects to Cordilleran ore districts, in which 
Zhai, D., Williams-Jones, A.E., Liu, J., Selby, D., Voudouris, P.C., Tombros, S., Li, K., Li, P., Sun, H., 2020.

The Genesis of the Giant Shuangjianzishan Epithermal Ag-Pb-Zn Deposit, Inner Mongolia, Northeastern China. Economic Geology, 115(1): 101-128.

porphyry deposits are associated with distal Ag-Pb-Zn deposits (Fontboté and Bendezú, 2009; Baumgartner et al., 2009), but there are also significant differences. The similarities include: ore (sulfide and a variety of Ag-bearing sulfosalts) and gangue (quartz and calcite) mineral assemblages; the ore paragenesis (base metal sulfides prior to Ag-bearing sulfosalts/sulfides); alteration zonation; high $\mathrm{Ag} / \mathrm{Au}$ ratios; open space filling and epigenetic veins structurally controlled by faults; formation under epithermal conditions at shallow levels $(<1 \mathrm{~km})$ from low temperature $\left(\sim 200^{\circ}\right.$ to $\left.250^{\circ} \mathrm{C}\right)$ and salinity $(\sim 1$ to 10 wt.\% $\mathrm{NaCl}$ equivalent) fluids; a magmatic source for the fluids and metal; and a close genetic association with porphyry systems (Baumgartner et al., 2009; Fontboté and Bendezú, 2009; Catchpole et al., 2015; Rottier et al., 2016, 2018a). An important difference is that the Cordilleran veins are commonly characterized by a $\mathrm{Cu}-\mathrm{Zn}-\mathrm{Pb}-(\mathrm{Ag}-\mathrm{Au}-\mathrm{Bi})$ metal suite (Fontboté and Bendezú, 2009), whereas the Shuangjianzishan deposit, as well as other Ag-Pb-Zn veins in the GHR, have a Ag-Pb-Zn-(Sn-Se-Sb) metal suite (Fig. 5); the Shuangjianzishan deposit is distinguished by rare Ag-bearing sulfosalts (i.e., candfiedite, Figs. 6A-D, 7), whereas the sulfosalts in the Cordilleran veins are dominantly Bi-bearing (e.g., cuprobismutite; Baumgartner et al., 2008). Moreover, a well-developed spatial zonation of ore and alteration minerals has been identified in many of the Cordilleran veins (Catchpole et al., 2015), whereas this is not observed in the Shuangjianzishan deposit and other Ag-Pb-Zn deposits in the GHR (Zhai et al., 2019a). Another significant difference is that the distal Ag-rich Peruvian deposits are hosted by carbonates (Fontboté and Bendezú, 2009), whereas the Shuangjianzishan deposit is hosted by slates (Fig. 2). The Cordilleran veins commonly formed in the shallow parts of porphyry Cu systems, in which both epithermal and porphyry-type mineralization are important (Baumgartner et al., 2008; Bendezú and Fontboté, 2009), whereas, although a close genetic relationship between the Shuangjianzishan Ag$\mathrm{Pb}-\mathrm{Zn}$ veins and a porphyry system has been established, the porphyry-type mineralization is very limited and other similar vein-type Ag-Pb-Zn deposits in the GHR are not associated with known porphyry-type mineralization. Finally, the GHR polymetallic vein deposits are related to post-subduction back-arc porphyry Mo systems, whereas the Cordilleran veins are commonly associated with subduction-related porphyry Cu systems (Fontboté and Bendezú, 2009; Catchpole et al., 2015). In conclusion, the model proposed for the giant Shuangjianzishan deposit emphasizes a genetic relationship between minor proximal Mo mineralization and considerable distal epithermal $\mathrm{Ag}-\mathrm{Pb}-\mathrm{Zn}$ mineralization. We expect that recognition of this relationship will provide an important guide for regional $\mathrm{Ag}-\mathrm{Pb}-\mathrm{Zn}$ exploration in NE China and elsewhere. 


\section{Acknowledgements}

This research was supported financially by the National Natural Science Foundation of China (Grant

41672068), the Fundamental Research Funds for the Central Universities (Grants 2652015045, 2652018129 and QZ05201904), the MOST Special Fund from the State Key Laboratory of Geological

Processes and Mineral Resources, China University of Geosciences (Grant MSFGPMR201804) and the Chinese "111" project (Grant B07011). We thank Li Su, Hongyu Zhang and Peng Xiang (CUGB) for performing the U-Pb analyses, Dongjie Tang (CUGB) for assistance with the SEM, and Zhenyu Chen and Xiaodan Chen (CAGS) for help with the microprobe analyses. Hegen Ouyang provided valuable insights into the ore deposit geology, and Xiaowen Huang helped with the interpretation of the Re-Os data. this manuscript was completed during DZ's visit to McGill University. Travel to and living expenses in Canada were supported financially by an international visiting program grant from the Fundamental Research Funds for the Central Universities, China. DS acknowledges the Total Endowment Fund and the CUG (Wuhan) scholarship. We thank Economic Geology reviewers Bertrand Rottier and Ryan Taylor, Associate Editor David John and Editor-in-Chief Larry Meinert for their insightful reviews, which helped improve this paper.

\section{References}

Alderton, D.H.M., and Brameld, F.C., 2006, Telluride mineralization at the Svetloye gold prospect, Khabarovsk Krai, eastern Russia. In: Cook NG, Özgenc I, Oyman T (eds) Au-Ag-Te-Se deposits, IGCP 486 field workshop, Izmir 24-29 September 2006, Proceedings, p. 1-5. Balabin, A.I., and Sack, R.O., 2000, Thermodynamics of (Zn, Fe)S sphalerite: a CVM approach with large basis clusters: Mineralogical Magazine, v. 64, p. 923-943.

Baumgartner, R., Fontboté, L., and Vennemann, T., 2008, Mineral zoning and geochemistry of epithermal polymetallic Zn-Pb-Ag-Cu-Bi mineralization at Cerro de Pasco, Peru: Economic Geology, v. 103, p. 493-537. epithermal polymetallic deposit, central Peru: A U-Pb and ${ }^{40} \mathrm{Ar} /{ }^{39} \mathrm{Ar}$ study: Economic Geology, v. 104, p. 
479-504.

Beaudoin, G., and Sangster, D.F., 1992, A descriptive model for silver-lead-zinc veins in clastic metasedimentary terranes: Economic Geology, v. 87, p. 1005-1021.

Bendezú, R., and Fontboté, L., 2002, Late timing for high sulfidation Cordilleran base metal lode and replacement deposits in porphyry-related districts: the case of Colquijirca, central Peru: SGA News, v. 13, p. 1-9.

Bendezú, R., and Fontboté, L., 2009, Cordilleran epithermal Cu-Zn-Pb-(Au-Ag) mineralization in the Colquijirca district, central Peru: Deposit-scale mineralogical patterns: Economic Geology, v. 104, p. 905944.

Black, L.P., Kamo, S.L., Allen, C.M., Aleinikoff, J.N., Davis, D.W., Korsch, R.J., and Foudoulis, C., 2003, TEMORA 1: a new zircon standard for Phanerozoic U-Pb geochronology: Chemical Geology, v. 200, p. 155-170.

Bonsall, T.A., Spry, P.G., Voudouris, P.C., Tombros, S., Seymour, K.S., and Melfos, V., 2011, The geochemistry of carbonate-replacement $\mathrm{Pb}-\mathrm{Zn}-\mathrm{Ag}$ mineralization in the Lavrion district, Attica, Greece: Fluid inclusion, stable isotope, and rare earth element studies: Economic Geology, v. 106, p. 619-651. Cai, J.H., Yan, G.H., Xiao, C.D., Wang, G.Y., Mu, B.L., and Zhang, R.H., 2004, Nd, Sr, Pb isotopic characteristics of the Mesozoic intrusive rocks in the Taihang Da Hinggan Mountains Tectonomagmatic Belt and their source region: Acta Petrologica Sinica, v. 20, p. 1225-1242 (in Chinese with English abstract).

Catchpole, H., Kouzmanov, K., Putlitz, B., Seo, J.H., and Fontboté, L., 2015, Zoned base metal mineralization in a porphyry system: Origin and evolution of mineralizing fluids in the Morococha district, Peru: Economic Geology, v. 110, p. 39-71.

Chang, Y., and Lai, Y., 2010, Study of characteristics of ore-forming fluid and chronology in the Yindu Ag$\mathrm{Pb}-\mathrm{Zn}$ polymetallic ore deposit, Inner Mongolia: Acta Scientiarum Naturalium Universitatis Pekinensis, v. 46, p. 581-593 (in Chinese with English abstract).

Chen, L., Chen, K., Bao, Z., Liang, P., Sun, T., and Yuan, H., 2017, Preparation of standards for in situ sulfur isotope measurement in sulfides using femtosecond laser ablation MC-ICP-MS: Journal of Analytical Atomic Spectrometry, v. 32, p. 107-116.

Chen, Y.J., Zhang, C., Wang, P., Pirajno, F., and Li, N., 2017, The Mo deposits of Northeast China: a powerful indicator of tectonic settings and associated evolutionary trends: Ore Geology Reviews, v. 81, 
p. $602-640$.

Chiaradia, M., 2014, Copper enrichment in arc magmas controlled by overriding plate thickness: Nature Geoscience, v. 7, p. 43. Sr/Y magmas?: Scientific reports, v. 2, p. 685 polymetallic deposit in Linxi county, Inner Mongolia, China - Implication for metallogenic elements from hypomagmatic source: Resource Geology, v. 51, p. 333-344.

Craddock, P.R., Rouxel, O.J., Ball, L.A., and Bach, W., 2008, Sulfur isotope measurement of sulfate and sulfide by high-resolution MC-ICP-MS: Chemical Geology, v. 253, p. 102-113. Shuangjianzishan Ag polymetallic deposit in Inner Mongolia: Master thesis, China University of Geosciences Beijing, Beijing, China, 55 p. (in Chinese with English abstract). Defant, M.J., and Drummond, M.S., 1993, Mount St. Helens: potential example of the partial melting of the subducted lithosphere in a volcanic arc: Geology, v. 21, p. 547-550. and Mo mineralization in Northeast China: geochronological and isotopic constraints from the Laojiagou porphyry Mo deposit: International Geology Review, v. 57, p. 55-75. Einaudi, M.T., 1981, Skarns associated with porphyry plutons: Description of deposits, southwestern North America. II. General features and origin. Advances in Geology of the Porphyry Copper Deposits of Southwestern North America. University of Arizona Press, Tucson, p. 139-183. Einaudi, M.T., Hedenquist, J.W., and Inan, E.E., 2003, Sulfidation state of fluids in active and extinct hydrothermal systems: transitions from porphyry to epithermal environments: Special PublicationSociety of Economic Geologists, v. 10, p. 285-314

Fontboté, L., and Bendezú, R., 2009, Cordilleran or Butte-type veins and replacement bodies as a deposit class in porphyry systems. In: Williams et al., P.J. (ed) Proceedings of the 10th Biennial Society of Geology Applied to Ore Deposits Meeting, Townsville, Australia, p. 521-523. of Asian Earth Sciences, v. 165, p. 7-36. 

growth: Lithos, v. 120, p. 563-578. abstract).

Heinrich, C.A., 2005, The physical and chemical evolution of low-salinity magmatic fluids at the porphyry to epithermal transition: a thermodynamic study: Mineralium Deposita, v. 39, p. 864-889. Irvine, T.N.J., and Baragar, W.R.A.F., 1971, A guide to the chemical classification of the common volcanic rocks: Canadian Journal of Earth Sciences, v. 8, p. 523-548. Ishiyama, D., Sato, R., Toshio, M., Yohei, I., and Wang, J.B., 2008, Characteristic features of tin-ironGeology, v. 51, p. 377-392. Jahn, B.M., 2004, The Central Asian Orogenic Belt and growth of the continental crust in the Phanerozoic. In: Malpas, J., Fletcher, C.J.N., Ali, J.R., Aitchison, J.C. (Eds.), Aspects of the tectonic evolution of China: growth in the Phanerozoic: Geological Society of America Special Papers, v. 350, p. 181-193. Geology, v. 13, p. 279-314. Shuangjianzishan silver-polymetallic deposit, Balinzuo Qi, Inner Mongolia: evidence from trace and rare earth elements: Acta Geologica Sinica, v. 92, p. 769-786 (in Chinese with English abstract). 
Mineral Exploration, v. 8, p. 1010-1019 (in Chinese with English abstract). events in the Baiyinnuoer $\mathrm{Zn}-\mathrm{Pb}$ deposit in Inner Mongolia, China: Evidence from field observations, SJiang, S.H., Liang, Q.L., Liu, Y.F., and Liu, Y., 2012, Zircon U-Pb ages of the magmatic rocks occurring in and around the Dajing $\mathrm{Cu}-\mathrm{Ag}-\mathrm{Sn}$ polymetallic deposit of Inner Mongolia and constrains to the oreforming age: Acta Petrologica Sinica, v. 28, p. 495-513 (in Chinese with English abstract). Jiang, S.H., Nie, F.J., Liu, Y.F., and Yun, F., 2010, Sulfur and lead isotopic compositions of Bairendaba and Weilasituo silver-polymetallic deposits, Inner Mongolia: Mineral Deposits, v. 28, p. 101-112 (in Chinese with English abstract).

Whalen, J.B., Currie, K.L., and Chappell, B.W., 1987, A-type granites: geochemical characteristics,

882 discrimination and petrogenesis: Contributions to Mineralogy and Petrology, v. 95, p. 407-419. pyrite-hosted $\mathrm{Au}(\mathrm{Ag}-\mathrm{Cu})$ ore formation by condensed magmatic vapors on Sangihe Island, Indonesia: Economic Geology, v. 109, p. 1705-1733. Kissin, S.A., and Mango, H., 2014, Silver Vein Deposits. Treatise on Geochemistry, Second Edition. Elsevier, Oxford, p. 425-432. of Shuangjianzishan silver polymetallic dposit in Chifeng City, Inner Mongolia: Mineral Deposits, v. 33, p. 847-856 (in Chinese with English abstract). Li, J.Y., 2006, Permian geodynamic setting of Northeast China and adjacent regions: closure of the 892 Paleo-Asian Ocean and subduction of the Paleo-Pacific Plate: Journal of Asian Earth Sciences, v. 26, p. 207-224.

Li, Y., Selby, D., Condon, D., and Tapster, S., 2017, Cyclic magmatic-hydrothermal evolution in porphyry systems: high-precision $\mathrm{U}-\mathrm{Pb}$ and Re-Os geochronology constraints on the Tibetan Qulong porphyry Cu-

897 Liu, C., Bagas, L., and Wang, F., 2016, Isotopic analysis of the super-large Shuangjianzishan Pb-Zn-Ag deposit in Inner Mongolia, China: Constraints on magmatism, metallogenesis, and tectonic setting: Ore Geology Reviews, v. 75, p. 252-267. 
of the Paleo-Pacific Oceanic plate in NE China: Constraints from whole-rock geochemistry and zircon U-

902

903

904

905

906

907

$\mathrm{Pb}$ and Lu-Hf isotopes of the Khanka Lake granitoids: Lithos, v. 274-275, p. 254-270.

Liu, Y., Jiang, S., and Bagas, L., 2016, The genesis of metal zonation in the Weilasituo and Bairendaba $\mathrm{Ag}-\mathrm{Zn}-\mathrm{Pb}-\mathrm{Cu}-(\mathrm{Sn}-\mathrm{W})$ deposits in the shallow part of a porphyry $\mathrm{Sn}-\mathrm{W}-\mathrm{Rb}$ system, Inner Mongolia, China: Ore Geology Reviews, v. 75, p. 150-173.

Ludwig, K.R., 2003, User's Manual for Isoplot 3.0: a Geochronological Toolkit for Microsoft Excel: Berkeley Geochronology Centre, Special Publication.

Maniar, P.D., and Piccoli, P.M., 1989, Tectonic discrimination of granitoids: Geological Society of America Bulletin, v. 101, p. 635-643.

Mao, J., Pirajno, F., Lehmann, B., Luo, M., and Berzina, A., 2014, Distribution of porphyry deposits in the Eurasian continent and their corresponding tectonic settings: Journal of Asian Earth Sciences, v. 79, p. 576-584.

Mao, J.W., Xie, G.Q., Zhang, Z.H., Li, X.F., Wang, Y.T., Zhang, C.Q., and Li, Y.F., 2005, Mesozoic large-scale metallogenic pluses in North China and corresponding geodynamic settings: Acta Petrologica Sinica, v. 21, p. 169-188 (in Chinese with English abstract).

McDonough, W.F., and Sun, S.S., 1995, The composition of the Earth: Chemical Geology, v. 120, p. 223253.

Meng, Q.R., 2003, What drove late Mesozoic extension of the northern China-Mongolia tract?: Tectonophysics, v. 369, p. 155-174.

Middlemost, E.A., 1994, Naming materials in the magma/igneous rock system: Earth-Science Reviews, v. 37 , p. 215-224.

Ohmoto H., 1972, Systematics of sulfur and carbon isotopes in hydrothermal ore deposits: Economic Geology, v. 67, p. 551-578.

Ouyang, H., Li, R., and Zhou, Z., 2016, The Jurassic mineralization of the Shuangjianzishan Agpolymetallic deposit and its significance in prospecting: evidence from geochronology: Acta Geologica Sinica, v. 90, p. 1835-1845 (in Chinese with English abstract).

Ouyang, H., Mao, J., Santosh, M., Wu, Y., Hou, L., and Wang, X., 2014, The Early Cretaceous Weilasituo $\mathrm{Zn}-\mathrm{Cu}-\mathrm{Ag}$ vein deposit in the southern Great Xing'an Range, northeast China: Fluid inclusions, H, O, S, $\mathrm{Pb}$ isotope geochemistry and genetic implications: Ore Geology Reviews, v. 56, p. 503-515.

Ouyang, H., Mao, J., Zhou, Z., and Su, H., 2015, Late Mesozoic metallogeny and intracontinental 
magmatism, southern Great Xing'an Range, northeastern China: Gondwana Research, v. 27, p. 11531172.

Pašava, J., Svojtka, M., Veselovský, F., Ďurišová, J., Ackerman, L., Pour, O., Drábek, M., Halodová, P., and Haluzová, E., 2016, Laser ablation ICPMS study of trace element chemistry in molybdenite coupled with scanning electron microscopy (SEM)-an important tool for identification of different types of mineralization: Ore Geology Reviews, v. 72, p. 874-895.

Pearce, J.A., Harris, N.B., and Tindle, A.G., 1984, Trace element discrimination diagrams for the tectonic interpretation of granitic rocks: Journal of Petrology, v. 25, p. 956-983.

Qi, J.P., Chen, Y.J., and Pirajno, F., 2005, Geological characteristics and tectonic setting of the epithermal deposits in the northeast China: Journal of Mineralogy and Petrology, v. 25, p. 47-59 (in Chinese with English abstract).

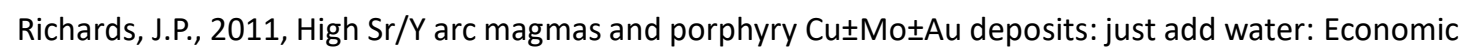
Geology, v. 106, p. 1075-1081.

Rickwood, P.C., 1989, Boundary lines within petrologic diagrams which use oxides of major and minor elements: Lithos, v. 22, p. 247-263.

Rottier, B., Kouzmanov, K., Casanova, V., Bouvier, A.S., Baumgartner, L.P., Wälle, M., and Fontboté, L., 2018a, Mineralized breccia clasts: a window into hidden porphyry-type mineralization underlying the epithermal polymetallic deposit of Cerro de Pasco (Peru): Mineralium Deposita, v. 53, p. 919-946.

Rottier, B., Kouzmanov, K., Casanova, V., Wälle, M., and Fontboté, L., 2018b, Cyclic dilution of magmatic metal-rich hypersaline fluids by magmatic low-salinity fluid: a major process generating the giant epithermal polymetallic deposit of Cerro de Pasco, Peru: Economic Geology, v. 113, p. 825-856.

Rottier, B., Kouzmanov, K., Wälle, M., Bendezú, R., and Fontboté, L., 2016, Sulfide replacement processes revealed by textural and LA-ICP-MS trace element analyses: example from the early mineralization stages at Cerro de Pasco, Peru: Economic Geology, v. 111, p. 1347-1367.

Rusk, B.G., Reed, M.H., and Dilles, J.H., 2008, Fluid inclusion evidence for magmatic-hydrothermal fluid evolution in the porphyry copper-molybdenum deposit at Butte, Montana: Economic Geology, v. 103, p. 307-334.

Sack, R.O., 2005, Internally consistent database for sulfides and sulfosalts in the system $\mathrm{Ag}_{2} \mathrm{~S}-\mathrm{Cu}_{2} \mathrm{~S}-\mathrm{ZnS}$ FeS-Sb $2 \mathrm{~S}_{3}-\mathrm{As}_{2} \mathrm{~S}_{3}$ : Update: Geochim Cosmochim Acta, v. 69, p. 1157-1164.

Seal, R.R., 2006, Sulfur isotope geochemistry of sulfide minerals: Reviews in Mineralogy and 
Geochemistry, v. 61, p. 633-677.

Seedorff, E., Dilles, J.H., Proffett, J.M., Einaudi, M.T., Zurcher, L., Stavast, W.J.A., Johnson, D.A., and Barton, M.D., 2005, Porphyry deposits: Characteristics and origin of hypogene features: Economic Geology $100^{\text {th }}$ Anniversary Volume, p. 251-298.

Selby, D., Creaser, R.A., Stein, H.J., Markey, R.J., and Hannah, J.L., 2007, Assessment of the ${ }^{187}$ Re decay constant by cross calibration of Re-Os molybdenite and $\mathrm{U}-\mathrm{Pb}$ zircon chronometers in magmatic ore systems: Geochimica et Cosmochimica Acta, v. 71, p. 1999-2013.

Shao, J.A., Mu, B.L., Zhu, H.Z., and Zhang, L.Q., 2010, Material source and tectonic settings of the Mesozoic mineralization or the Da Hinggan Mts: Acta Petrologica Sinica, v. 26, p. 649-656 (in Chinese with English abstract).

Shen, J.F., and Fu, X.Z., 1999, The metallogenic environment and geology of copper polymetallic deposits in the Middle segment of Great Xing'an Range: Geological Publishing House, Beijing (in Chinese).

Shimizu, M., Shimizu, M., Furuhashi, T., Harada, A., and Cook, N., 2008, Indium mineralization in epithermal Au-Ag-Cu-Mn-Te-(Se-Bi-Sn-Mo-In) vein-type deposits of the Kawazu (Rendaiji) mine, Shizuoka Prefecture, Japan: Intern Geol Congr Olso, MRD-09 Au-Ag-telluride-selenide deposits, Abstract. Shu, Q., Chang, Z., Lai, Y., Zhou, Y., Sun, Y., and Yan, C., 2016, Regional metallogeny of Mo-bearing deposits in northeastern China, with new Re-Os dates of porphyry Mo deposits in the northern Xilamulun district: Economic Geology, v. 111, p. 1783-1798.

Shvarov, Y., 2011, Unitherm Software, version 4.4.

Sillitoe, R.H, 2010, Porphyry copper systems: Economic geology, v. 105, p. 3-41.

Smoliar, M.I., Walker, R.J., and Morgan, J.W., 1996, Re-Os ages of group IIA, IIIA, IVA, and IVB iron meteorites: Science, v. 271, p. 1099-1102.

So, C.S., Dunchenko, V.Y., Yun, S.T., Park, M.E., Choi, S.G., and Shelton, K.L., 1995, Te- and Se-bearing epithermal Au-Ag mineralization, Prasolovskoye, Kunashir Island, Kuril Island arc: Economic Geology, v. 90, p. $105-117$.

Stein, H.J., Morgan, J.W., and Scherstén, A., 2000, Re-Os dating of low-level highly radiogenic (LLHR) sulfides: The Harnas gold deposit, southwest Sweden, records continental-scale tectonic events: Economic Geology, v. 95, p. 1657-1671.

Stern, R.A., and Amelin, Y., 2003, Assessment of errors in SIMS zircon U-Pb geochronology using a 
natural zircon standard and NIST SRM 610 glass: Chemical Geology, v. 197, p. 111-142.

Sun, S.S., and McDonough, W.S., 1989, Chemical and isotopic systematics of oceanic basalts: implications for mantle composition and processes: Geological Society, London, Special Publications, v. 42, p. 313-345.

Sun, W., Zhang, H., Ling, M.X., Ding, X., Chung, S.L., Zhou, J., Yang, X.Y., and Fan, W., 2011, The genetic association of adakites and Cu-Au ore deposits: International Geology Review, v. 53, p. 691-703. Voudouris, P., 2011, Conditions of formation of the Mavrokoryfi high-sulfidation epithermal Cu-Ag-AuTe mineralization (Petrota Graben, NE Greece): Mineralogy and Petrology, v. 101, p. 97-113.

Wang, C., 2015, Lead-zinc polymetallic metallogenic series and prospecting direction of Huanggangliang-ganzhuermiao metallogenic belt, Inner Mongolia: Ph.D. thesis, Changchun, China, Jilin University, 165 p. (in Chinese with English abstract).

Wang, F., 2017, Magmatism and Ag-polymetallic mineralization in Shuangjianzishan deposit and its periphery, Inner Mongolia: Ph.D. thesis, Wuhan, China, China University of Geosciences, 176 p. (in Chinese with English abstract).

Wang, F., Bagas, L., Jiang, S., and Liu, Y., 2017, Geological, geochemical, and geochronological characteristics of Weilasituo Sn-polymetal deposit, Inner Mongolia, China: Ore Geology Reviews, v. 80, p. $1206-1229$.

Wang, F., Sun, H., Pei, R., Liu, Y., Liu, C., and Jiang, S., 2016, The geologic features and genesis of Shuangjianzishan silver-polymetallic deposit, Balinzuo Qi, Inner Mongolia: Geological Review, v. 62, p. 1241-1256 (in Chinese with English abstract).

Wang, F., Zhou, X.H., Zhang, L.C., Ying, J.F., Zhang, Y.T., and Wu, F.Y., 2006, Timing of volcanism succession of the Great Xing'an Range, northeastern Asia, and its tectonic significance: Earth Planetary Science Letters, v. 251, p. 179-198.

Wang, J., 2009, Chronology and geochemistry of granitoid for the Weilasituo copper polymetal deposit in Inner Mongolia: Master thesis, China University of Geosciences Beijing, Beijing, China, 68 p. (in Chinese with English abstract).

Wang, J.B., Wang, Y.W., Wang, L.J., and Uemoto, T., 2001, Tin-polymetallic mineralization in the southern part of the Da Hinggan Mountains, China: Resource Geology, v. 51, p. 283-291.

Wang, T., Guo, L., Zheng, Y.D., Donskaya, T., Gladkochub, D., Zeng, L.S., Li, J.B., Wang, Y.B., and Mazukabzov, A., 2012, Timing and processes of late Mesozoic mid-lower-crustal extension in continental 
NE Asia and implications for the tectonic setting of the destruction of the North China Craton: mainly constrained by zircon U-Pb ages from metamorphic core complexes: Lithos, v. 154, p. 315-345.

Wang, X.D., 2017, Magmatism and mineralization of Ag-Pb-Zn polymetallic deposits in the Lindong district, Inner Mongolia: Ph.D. thesis, Wuhan, China, China University of Geosciences, 175 p. (in Chinese with English abstract).

Wei, C.S., Zhao, Z.F., and Spicuzza, M.J., 2008, Zircon oxygen isotopic constraint on the sources of late Mesozoic A-type granites in eastern China: Chemical Geology, v. 250, p. 1-15.

Wiedenbeck, M., Alle, P., Corfu, F., Griffin, W.L., Meier, M., Oberli, F., Von Quadt, A., Roddick, J.C., and Spiegel, W., 1995, Three natural zircon standards for U-Th-Pb, Lu-Hf, trace element and REE analyses: Geostandards Newsletter, v. 19, p. 1-23.

Wilde, S.A., 2015, Final amalgamation of the Central Asian Orogenic Belt in NE China: Paleo-Asian Ocean closure versus Paleo-Pacific plate subduction-A review of the evidence: Tectonophysics, v. 662, p. 345362.

Wilkinson, J.J., 2013, Triggers for the formation of porphyry ore deposits in magmatic arcs: Nature Geoscience, v. 6, p. 917.

Williams-Jones, A.E., and Heinrich, C.A., 2005, 100th Anniversary special paper: Vapor transport of metals and the formation of magmatic-hydrothermal ore deposits: Economic Geology, v. 100, p. 12871312.

Williams-Jones, A.E., and Migdisov, A.A., 2014, Experimental constraints on the transport and deposition of metals in ore-forming hydrothermal systems: Society of Economic Geologists, v. 18, p. $77-$ 96.

Wood, S.A., 1998, Calculation of activity-activity and $\log \mathrm{fO}_{2}-\mathrm{pH}$ diagrams: Reviews in Economic Geology, v. 10, p. 81-96.

Wu, F.Y., Lin, J.Q., Wilde, S.A., Zhang, X.O., and Yang, J.H., 2005, Nature and significance of the Early Cretaceous giant igneous event in eastern China: Earth and Planetary Science Letters, v. 233, p. 103-119. Wu, F.Y., Sun, D.Y., Ge, W.C., Zhang, Y.B., Grant, M.L., Wilde, S.A., and Jahn, B.M., 2011, Geochronology of the Phanerozoic granitoids in northeastern China: Journal of Asian Earth Sciences, v. 41, p. 1-30. Wu, F.Y., Sun, D.Y., Li, H.M., Jahn, B.M., and Wilde, S.A., 2002, A-type granites in northeastern China: age and geochemical constraints on their petrogenesis: Chemical Geology, v. 187, p. 143-173. Wu, G., 2014, Research of silver mineralization in central-southern segment of the Great Xing'an Range 
- A case study of the Shuangjianzishan silver deposit, Inner Mongolia: Ph.D. thesis, University of Chinese Academy of Sciences, Beijing, China, 136 p. (in Chinese with English abstract).

Wu, G., Liu, J., Zeng, Q., Liu, M., Sun, H., Yin, Z., and Yin, X., 2014, Occurrences of silver in the Shuangjianzishan $\mathrm{Pb}-\mathrm{Zn}-\mathrm{Ag}$ deposit and its implications for mineral processing: Earth Science Frontiers, v. 21, p. 105-115 (in Chinese with English abstract).

Wu, G., Liu, J., Zeng, Q., Sun, H., and Liu, M., 2013, The metallogenic age of Shuangjianzishan Ag-Pb-Zn deposit of Greate Hinggan Range, Inner Mongolia: Acta Mineralogica Sinica, v. 33, p. 619 (in Chinese). Wu, X.L., Mao, J.W., Zhou, Z.H., and Ouyang, H.G., 2012, H-O-S-Pb isotopic components of the Budunhua Cu deposit in the middle-south part of the Da Hinggan Mountains and their implications for the ore-forming process: Geology in China, v. 39, p. 1812-1829 (in Chinese with English abstract).

Xiao, W.J., Zhang, L.C., Qin, K.Z., Sun, S., and Li, J.L., 2004, Paleozoic accretionary and collisional tectonics of the eastern Tianshan China: Implication for the continental growth of central Asia: American Journal of Science, v. 304, p. 370-395.

Yao, M.J., Liu, J.J., Zhai, D.G., and Wang, J.P., 2012, Sulfur and lead isotopic compositions of the polymetallic deposits in the southern Great Xing'an Range: some implications for metal sources: Journal of Jilin University (Earth Science Edition), v. 42, p. 362-373 (in Chinese with English abstract).

Yuan, H., Yin, C., Liu, X., Chen, K., Bao, Z., Zong, C., Dai, M., Lai, S., Wang, R., and Jiang, S., 2015, High precision in-situ $\mathrm{Pb}$ isotopic analysis of sulfide minerals by femtosecond laser ablation multi-collector inductively coupled plasma mass spectrometry: Science China Earth Sciences, v. 58, p. 1713-1721.

Zeng, Q., Liu, J., Chu, S., Guo, Y., Gao, S., Guo, L., and Zhai, Y., 2016, Poly-metal mineralization and exploration potential in southern segament of the Da Hinggan Mountains: Journal of Jilin University (Earth Science Edition), v. 46, p. 1100-1123 (in Chinese with English abstract).

Zeng, Q., Qin, K., Liu, J., Li, G., Zhai, M., Chu, S., and Guo, Y., 2015, Porphyry molybdenum deposits in the Tianshan-Xingmeng orogenic belt, northern China: International Journal of Earth Sciences, v. 104, p. 991-1023.

Zeng, Q.D., Liu, J.M., Zhang, Z.L., Chen, W.J., and Zhang, W.Q., 2011, Geology geochronology of the Xilamulun molybdenum metallogenic belt in eastern Inner Mongolia, China: International Journal of Earth Sciences, v. 100, p. 1791-1809. 
Zeng, Q.D., Liu, J.M., Zhang, Z.L., Jia, C.S., Yu, C.M., Ye, J., and Liu, H.T., 2009, Geology and lead-isotope study of the Baiyinnuoer Zn-Pb-Ag deposit, south segment of the Da Hinggan Mountains, Northeastern China: Resource Geology, v. 59, p. 170-180.

Zhai, D., Bindi, L., Voudouris, P.C., Liu, J., Tombros, S.F., and Li, K., 2018b, Discovery of Se-rich canfieldite, $\mathrm{Ag}_{8} \mathrm{Sn}(\mathrm{S}, \mathrm{Se})_{6}$, from the Shuangjianzishan Ag-Pb-Zn deposit, NE China: A multimethodic chemical and structural study: Mineralogical Magazine, https://doi.org/10.1180/mgm.2018.158.

Zhai, D., Williams-Jones, A.E., Liu, J., Selby, D., Li, C., Huang, X.W., Qi, L., and Guo, D., 2019b, Evaluating the use of the molybdenite Re-Os chronometer in dating gold mineralization: Evidence from the Haigou deposit, NE China: Economic Geology (in press).

Zhai, D., Liu, J., Cook, N.J., Wang, X., Yang, Y., Zhang, A., and Jiao, Y., 2019a, Mineralogical, textural, sulfur and lead isotope constraints on the origin of Ag-Pb-Zn mineralization at Bianjiadayuan, Inner Mongolia, NE China: Mineralium Deposita, v. 54, p. 47-66.

Zhai, D., Williams-Jones, A.E., Liu, J., Tombros, S.F., Cook, N.J., 2018a, Mineralogical, fluid inclusion and multiple isotope (H-O-S-Pb) constraints on the genesis of the Sandaowanzi epithermal Au-Ag-Te deposit, NE China: Economic Geology, v. 113, p. 1359-1382.

Zhai, D., Liu, J., Li, J., Zhang, M., Li, B., Fu, X., Jiang, H., Ma, L., and Qi, L., 2016, Geochronological study of Weilasituo porphyry type Sn deposit in Inner Mongolia and its geological significance: Mineral Deposits, v. 35, p. 1011-1022 (in Chinese with English abstract).

Zhai, D., Liu, J., Ripley, E.M., and Wang, J., 2015, Geochronological and He-Ar-S isotopic constraints on the origin of the Sandaowanzi gold-telluride deposit, northeastern China: Lithos, v. 212, p. 338-352. Zhai, D., Liu, J., Tombros, S., and Williams-Jones, A.E., 2018c, The genesis of the Hashitu porphyry molybdenum deposit, Inner Mongolia, NE China: constraints from mineralogical, fluid inclusion, and multiple isotope (H, O, S, Mo, Pb) studies: Mineralium Deposita, v. 53, p. 377-397.

Zhai, D., Liu, J., Wang, J., Yang, Y., Zhang, H., Wang, X., Zhang, Q., Wang, G., and Liu, Z., 2014a, Zircon U$\mathrm{Pb}$ and molybdenite Re-Os geochronology, and whole-rock geochemistry of the Hashitu molybdenum deposit and host granitoids, Inner Mongolia, NE China: Journal of Asian Earth Sciences, v. 79, p. 144160.

Zhai, D., Liu, J., Zhang, A., and Sun, Y., 2017, U-Pb, Re-Os and ${ }^{40} \mathrm{Ar} /{ }^{39} \mathrm{Ar}$ geochronology of porphyry $\mathrm{Sn} \pm$ $\mathrm{Cu} \pm \mathrm{Mo}$ and polymetallic (Ag-Pb-Zn-Cu) vein mineralization at Bianjiadayuan, Inner Mongolia, NE China: Implications for discrete mineralization events: Economic Geology, v. 112, p. 2041-2059.

Zhai, D., Liu, J., Zhang, H., Tombros, S., and Zhang, A., 2018d, A magmatic-hydrothermal origin for Ag$\mathrm{Pb}-\mathrm{Zn}$ vein formation at the Bianjiadayuan deposit, Inner Mongolia, NE China: Evidences from fluid inclusion, stable (C-H-O) and noble gas isotope studies: Ore Geology Reviews, v. 101, p. 1-16.

Zhai, D., Liu, J., Zhang, H., Yao, M., Wang, J., and Yang, Y., 2014b, S-Pb isotopic geochemistry, U-Pb and 
Re-Os geochronology of the Huanggangliang Fe-Sn deposit, Inner Mongolia, NE China: Ore Geology Reviews, v. 59, p. 109-122.

Zhang, F.Q., Chen, H.L., Yu, X., Dong, C.W., Yang, S.F., Pang, Y.M., and Batt, G.E., 2011, Early Cretaceous volcanism in the northern Songliao Basin, NE China, and its geodynamic implication: Gondwana Research, v. 19, p. 163-176.

Zhang, J.H., Gao, S., Ge, W.C., Wu, F.Y., Yang, J.H., Wilde, S.A., and Li, M., 2010, Geochronology of the Mesozoic volcanic rocks in the Great Xing'an Range, northeastern China: implications for subductioninduced delamination: Chemical Geology, v. 276, p. 144-165.

Zhang, L.C., Zhou, X.H., Ying, J.F., Wang, F., Guo, F., Wan, B., and Chen, Z.G., 2008, Geochemistry and $\mathrm{Sr}-\mathrm{Nd}-\mathrm{Pb}-\mathrm{Hf}$ isotopes of Early Cretaceous basalts from the Great Xinggan Range, NE China: Implications for their origin and mantle source characteristics: Chemical Geology, v. 256, p. 12-23.

Zhang, L.G., Liu, J.X., and Wang, K.F., 1995, Block geology of eastern Asia lithosphere: Isotope geochemistry and dynamics of upper mantle, basement and granite. Beijing: Science Press, 252 p. (in Chinese with English abstract).

Zhang, Z., 2018, Geological and geochemical characteristics and metallogenic mechanism of the Shuangjianzishan Ag-polymetallic deposit, Inner Mongolia, Master thesis, Beijing, China, China University of Geosciences Beijing, 64 p. (in Chinese with English abstract).

Zhou, J.B., Wilde, S.A., Zhao, G.C., and Han, J., 2018, Nature and assembly of microcontinental blocks within the Paleo-Asian Ocean: Earth-Science Reviews, v. 186, p. 76-93.

Zhou, Z.H., Ouyang, H.G., Wu, X.L., Liu, J., and Che, H.W., 2014, Geochronology and geochemistry study of the biotite granite from the Daolundaba Cu-W polymetallic deposit in the Inner Mogolia and its geological significance: Acta Petrologica Sinica, v. 30, p. 79-94 (in Chinese with English abstract).

Zhu, X.Y., Zhang, Z.H., Fu, X., Li, B.Y., Wang, Y.L., Jiao, S.T., and Sun, Y.L., 2016, Geological and geochemical characteristics of the Weilasito Sn-Zn deposit, Inner Mongolia: Geology in China, v. 43, p. 188-208 (in Chinese with English abstract).

\section{Figure Captions}

Figure 1 (A) A tectonic map of the Central Asian Orogenic Belt (based on Jahn et al., 2000); (B) A geological map of the Great Hinggan Range (GHR) in NE China showing the distribution of the Mesozoic granites and volcanic rocks (modified from Qi et al., 2005); (C) A geological map of the southern GHR 
showing the locations and ages of major ore deposits (modified from Zhai et al., 2017).

Figure 2 (A) A geological map of the Shuangjianzishan ore district (based on Wu et al., 2014); (B) A vertical section through the ore deposit (modified from Wang, 2015).

Figure 3 Core logs of two drill holes showing the distribution of granite porphyry and Mo mineralization

(A), and a diorite dike and Ag-Pb-Zn mineralization (B). Also shown are the locations of samples used in geochronological analyses. Abbreviations: Ab-albite; Mo-molybdenite; Cal-calcite; Qtz-quartz.

Figure 4 (A) Oxidized mineralized veins hosted in slate near the erosional surface; (B) Major and parallel Ag-Pb-Zn-quartz veins hosted by slate associated with an alteration assemblage of chlorite-sericitequartz; (C) Early formed pyrite veinlets within slate enclosed as breccias in subsequent massive $\mathrm{Ag}-\mathrm{Pb}$ Zn quartz-calcite veins; (D) Early quartz-pyrite veins crosscut by Ag-Pb-Zn mineralized quartz-calcite veins, and a late stage quartz vein crosscutting the Ag-Pb-Zn mineralized veins; (E) Massive Ag- $\mathrm{Pb}-\mathrm{Zn}$ ore with a very high $\mathrm{Ag}$ grade $(>32,000 \mathrm{~g} / \mathrm{t})$ from a major mineralized vein; $(\mathrm{F})$ Massive sulfide ore comprising galena, sphalerite and pyrite; (G) Slate as breccia fragments cemented by quartz, calcite and sulfides. Abbreviations: Cal-calcite; Chl-chlorite; Gn-galena; Py-pyrite; Q-Quaternary gravel; Qtz-quartz;

Figure 5 The paragenetic sequence for the Shuangjianzishan Ag-Pb-Zn mineralization.

Figure 6 Photomicrographs of ore textures involving silver-bearing minerals, and mineral assemblages from the Shuangjianzishan deposit. (A) Galena and sphalerite replaced by argentite and canfieldite coexisting with sericite and quartz (BSE); (B) Early pyrite surrounded by later chalcopyrite, which was replaced by argentite and canfieldite (reflected light); (C) Canfiedite intergrown with freibergite that replaced sphalerite and galena (reflected light); (D) Galena and chalcopyrite associated with freibergite and canfieldite (reflected light); (E) Argentite after galena, sphalerite and chalcopyrite (BSE); (F) Late argentite as veins cutting galena (reflected light); (G) Ellipsoidal inclusions of freibergite, pyrargyrite and pyrrhotite within galena (BSE); $(\mathrm{H})$ Coexisting stephanite and freibergite that replaced galena and sphalerite (reflected light); (I) Polybasite associated with quartz and sericite after galena (BSE). 
Abbreviations: Arg-argentite; Caf-canfieldite; Ccp-chalcopyrite; Frb-freibergite; Gn-galena; Popyrrhotite; Pol-polybasite; Py-pyrite; Pyr-pyrargyrite; Qtz-quartz; Sec-sericite; Sp-sphalerite; Stestephanite.

Figure 7 Reflected light (A) and EPM element maps (B-I) of canfieldite and argentite. Abbreviations: Argargentite; Caf-canfieldite; Cas-cassiterite; Ccp-chalcopyrite; Sp-sphalerite.

Figure 8 Locations of in situ spot sulfur isotopic analyses of sulfide and sulfosalt minerals and corresponding $\delta^{34} S$ values. (A): Galena and sphalerite; (B): A single galena crystal; (C): Freibergite and galena; (D): Pyrargyrite, canfieldite and galena. Abbreviations: Caf-canfieldite; Frb-freibergite; Gngalena; Ccp-chalcopyrite; Pyr-pyrargyrite; Qtz-quartz; Sp-sphalerite.

Figure 9 (A) A histogram of $\delta^{34} S$ values for various ore minerals from the different ore stages; (B) $\delta^{34} \mathrm{~S}$ values for ore minerals versus depth.

Figure 10 Binary plots of ${ }^{206} \mathrm{~Pb} /{ }^{204} \mathrm{~Pb}$ vs. ${ }^{207} \mathrm{~Pb} /{ }^{204} \mathrm{~Pb}(\mathrm{~A})$ and ${ }^{206} \mathrm{~Pb} /{ }^{204} \mathrm{~Pb}$ vs. ${ }^{208} \mathrm{~Pb} /{ }^{204} \mathrm{~Pb}(\mathrm{~B})$ for ore minerals from the Shuangjianzishan deposit.

Figure 11 Zircon U-Pb ages for igneous rocks from the Shuangjianzishan deposit. (A): Diorite dike; (B): Dacite; (C): Granite intrusion; (D): Coarse-grained granite porphyry; (E): Fine-grained granite porphyry.

Figure 12 Molar $\mathrm{Ag} /(\mathrm{Ag}+\mathrm{Cu})$ and $\mathrm{Zn} /(\mathrm{Zn}+\mathrm{Fe})$ plots for primary freibergite in the Shuangjianzishan deposit. The isotherms were calculated from Sack (2005). These isotherms terminate at low $\mathrm{Zn} /(\mathrm{Zn}+\mathrm{Fe})$ and high $\mathrm{Ag} /(\mathrm{Ag}+\mathrm{Cu})$ values because of saturation with respect to pyrrhotite (Po) (Balabin and Sack, 2000).

Figure 13 Lead isotope plots of the Shuangjianzishan ore minerals compared to local magmatichydrothermal deposits and various rock units. The $\mathrm{Pb}$ isotope data for local Mesozoic granite, andesite and basalt, Paleozoic granite, Permian slate, and sulfides from the nearby magmatic-hydrothermal deposits were taken from the literature (Zhang et al., 1995, 2008; Shen and Fu, 1999; Chu et al., 2001; 

Shuangjianzishan deposit are similar to those of the local Mesozoic granite and adjacent ore deposits. (A): ${ }^{206} \mathrm{~Pb} /{ }^{204} \mathrm{~Pb}$ vs. ${ }^{207} \mathrm{~Pb} /{ }^{204} \mathrm{~Pb}$ plots; (B): ${ }^{206} \mathrm{~Pb} /{ }^{204} \mathrm{~Pb}$ vs. ${ }^{208} \mathrm{~Pb} /{ }^{204} \mathrm{~Pb}$ plots.

Figure $14 \mathrm{LogfO}_{2}-\mathrm{pH}$ diagrams showing stability relationships in the Fe-O-S system and alteration assemblages for $\mathrm{Ag}-\mathrm{Pb}-\mathrm{Zn}$ mineralization in the Shuangjianzishan deposit at $250{ }^{\circ} \mathrm{C}(\mathrm{A})$ and $200{ }^{\circ} \mathrm{C}(\mathrm{B})$ and vapor-saturated water pressure. The calculations assumed an aqueous fluid with $0.01 \mathrm{~m} \Sigma \mathrm{S}$ and a $\delta^{34} S_{\Sigma s}$ value of $+0.5 \%$. The diagrams show the predominance boundaries of aqueous sulfur species (pink dashed), mineral stability in the Fe-O-S system (black solid), alteration equilibra (grey solid), and calcite dissolution (black dashed). The kaolinite-muscovite and K-feldspar-muscovite stability fields are for a solution containing $0.001 \mathrm{~m} \mathrm{~K}^{+}$. The stability boundary for calcite is for $\Sigma \mathrm{C}=1 \mathrm{~m}$ (based on Ohmoto, 1972). The sulfur isotope contours are indicated by blue lines. The grey area represents the approximate stability field for the ore minerals. Phase and predominance boundaries were constructed using the $\mathrm{HCh}$ software package (Shvarov, 2011). Abbreviations: Hem-hematite; Kfs-K-feldspar; KIn-kaolinite; Magmagnetite; Po-pyrrhotite; Py-pyrite; Mus-muscovite.

Figure 15 (A) A chronology of magmatic and mineralization events in the Shuangjianzishan ore district; some of the data are from the literature (Wu, 2014; Cui, 2015; Liu, C., et al., 2016; Gu et al., 2017; Zhang, 2018). The uncertainty for all the data is $2 \sigma ;(B)-(D)$ : Cartoons illustrating the sequence of magmatic and mineralizing events from $\sim 252$ to $132 \mathrm{Ma}$ in the Shuangjianzishan ore district.

\section{Appendix Data}

Figure A1 A total alkali vs. silica diagram illustrating the classification of the magmatic rocks at Shuangjianzishan (after Middlemost, 1994). The alkaline/ subalkaline boundary is from Irvine and Baragar (1971). Some of the petrochemical data are from Gu et al. (2017) and Zhang (2018). 
Figure A3 Trace element diagrams for the granite porphyry and dacite. (A) Rare earth element profiles normalized to the $\mathrm{Cl}$ chondrite of McDonough and Sun (1995); (B) Spider diagram of trace elements normalized to the primitive mantle composition of Sun and McDonough (1989).

Figure A4 A histogram of temperatures determined using sulfur isotope geothermometry.

Figure $\mathrm{A} 5$ Comparisons of the $\mathrm{Pb}$ isotope ratios obtained using in situ and conventional (mineral separates) analytical methods; the mineral separate data are from Wang, F. (2017). (A): ${ }^{206} \mathrm{~Pb} /{ }^{204} \mathrm{~Pb}$ versus ${ }^{207} \mathrm{~Pb} /{ }^{204} \mathrm{~Pb}$; (B): ${ }^{206} \mathrm{~Pb} / 204 \mathrm{~Pb}$ versus ${ }^{208} \mathrm{~Pb} /{ }^{204} \mathrm{~Pb}$.

Figure A6 Trace element tectonic discrimination diagrams. (A) Sr/Y versus Y (Defant and Drummond, 1993); (B) $\mathrm{Y}+\mathrm{Nb}$ versus $\mathrm{Rb}$ (Pearce et al., 1984).

Table A1 Electron microprobe-determined compositions of sulfides and sulfosalts from the Shuangjianzishan Ag-Pb-Zn deposit (wt.\%). deposit. 







\section{(A) $\stackrel{N}{N}$}

Fig 2 $500 \mathrm{~m}$

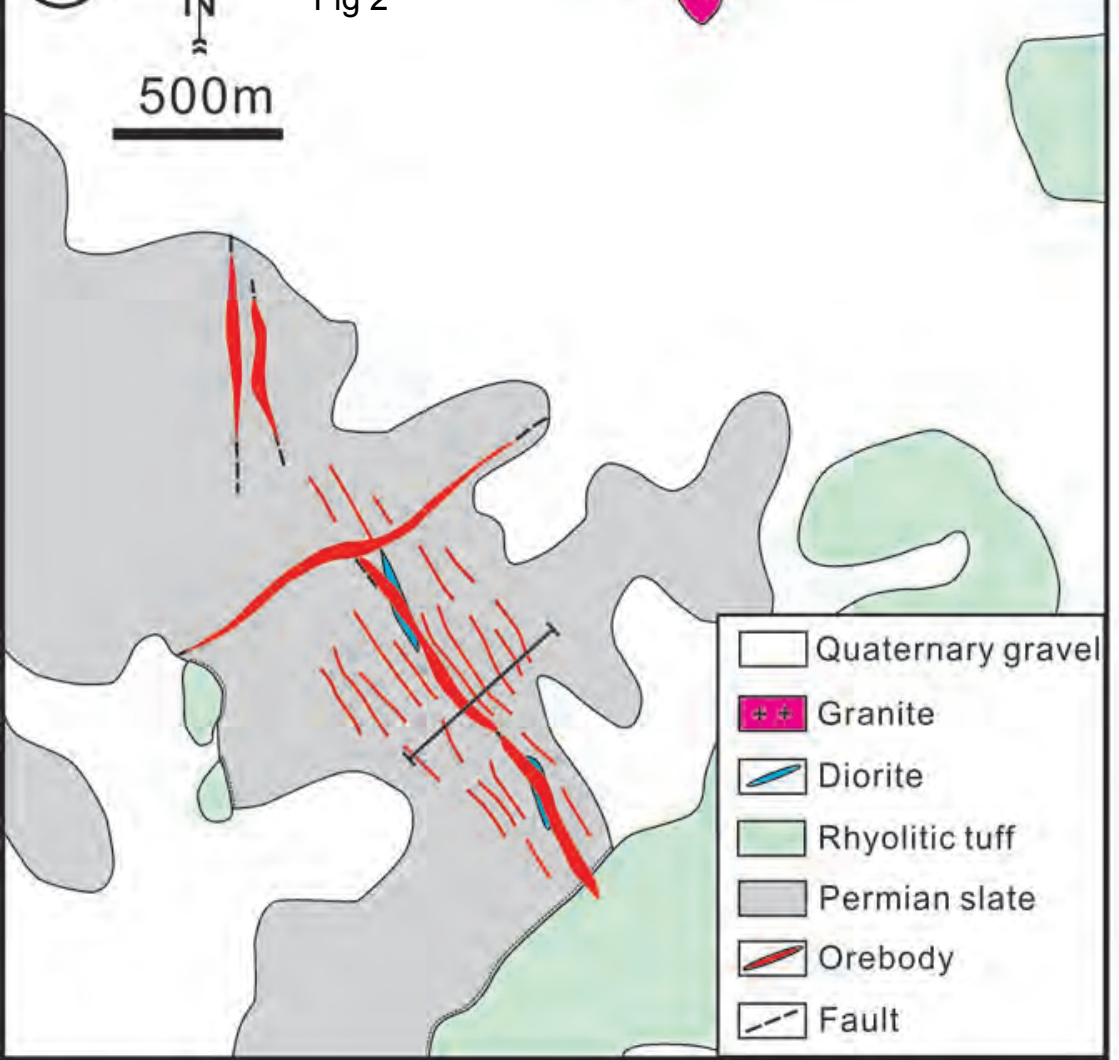

ZK08-1 ZK08-18 ZK09-7 ZK08-7 ZK09-17

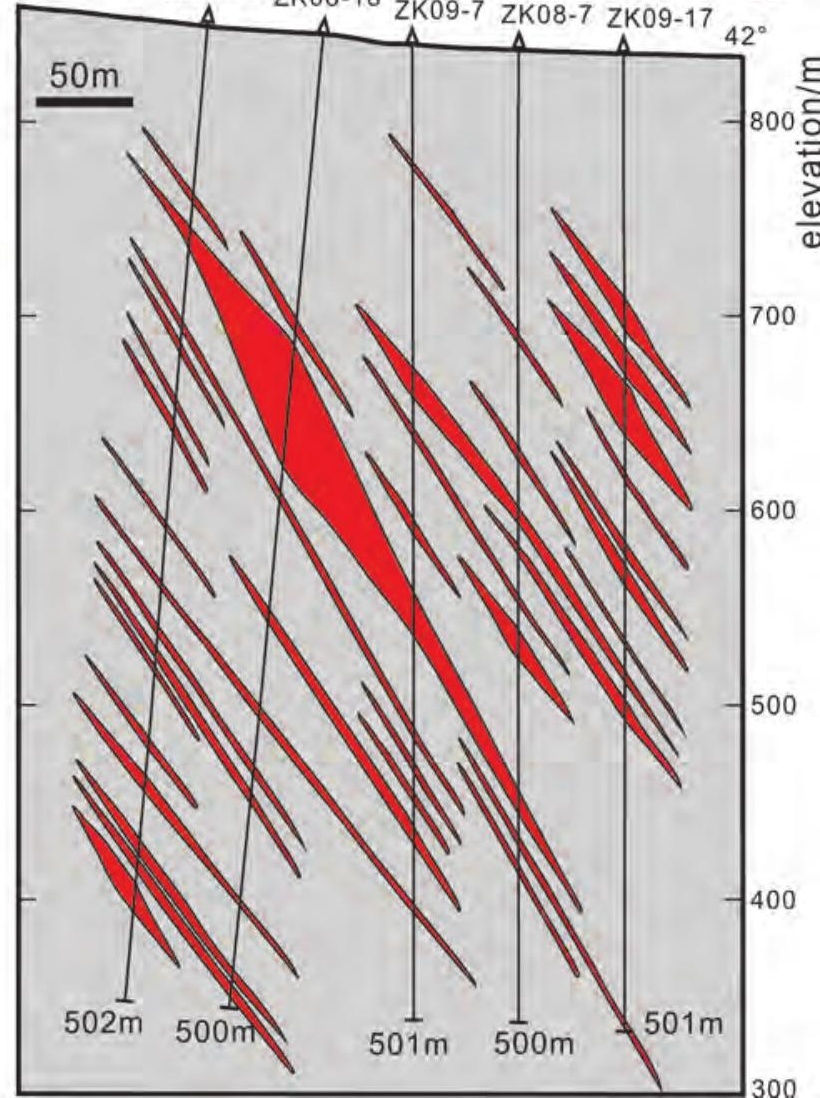











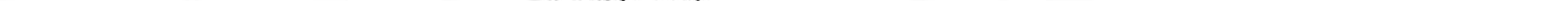




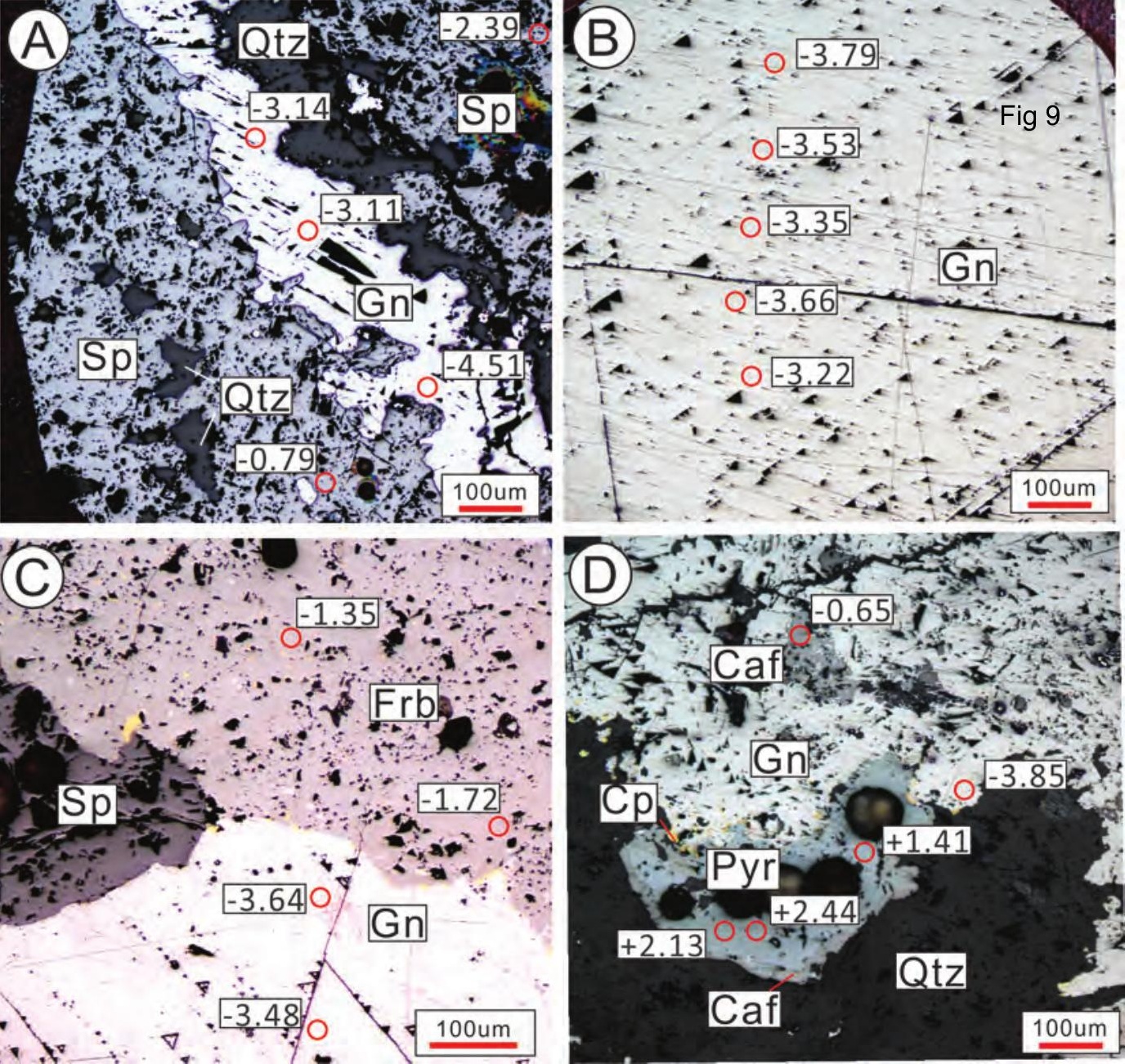




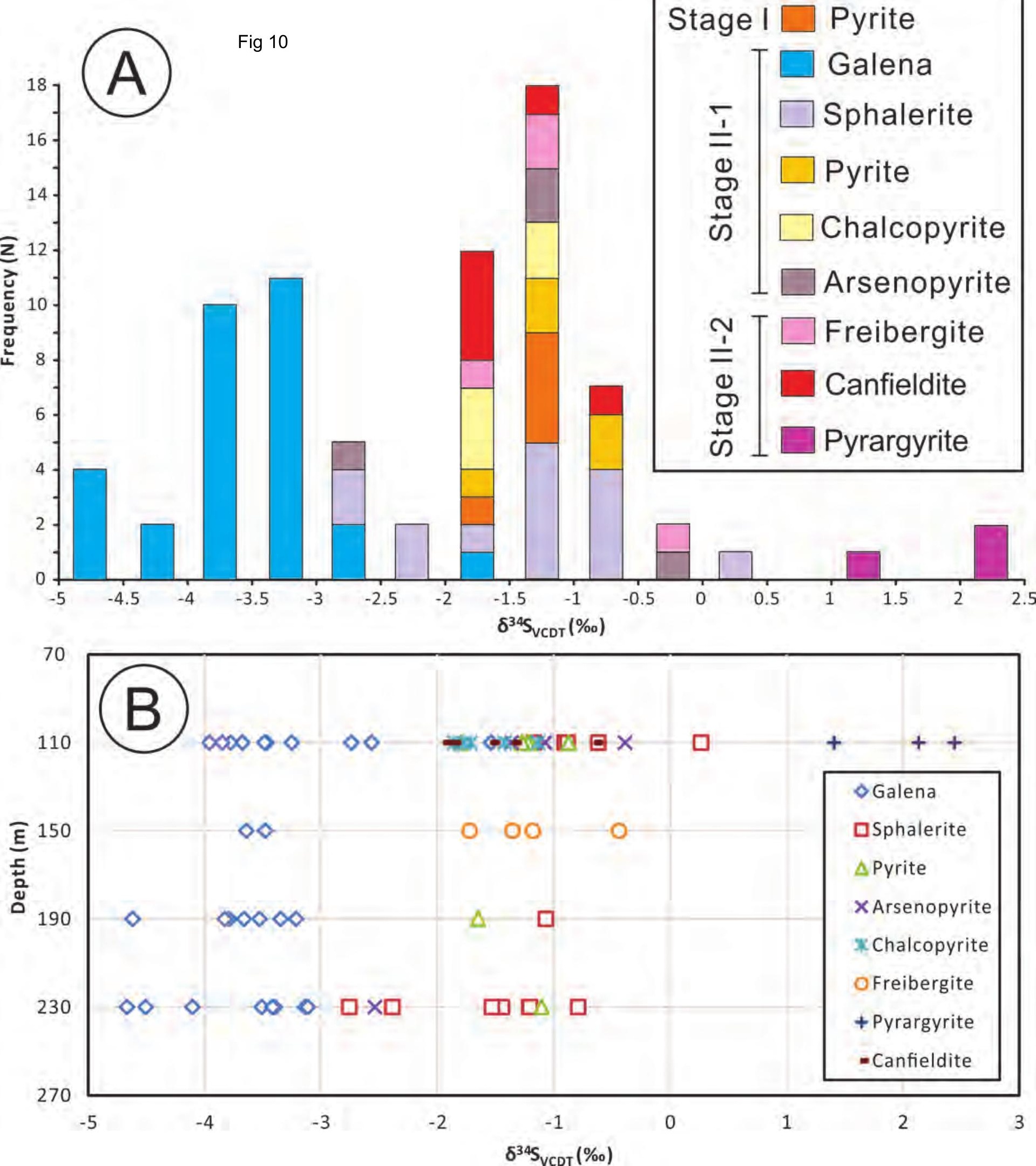




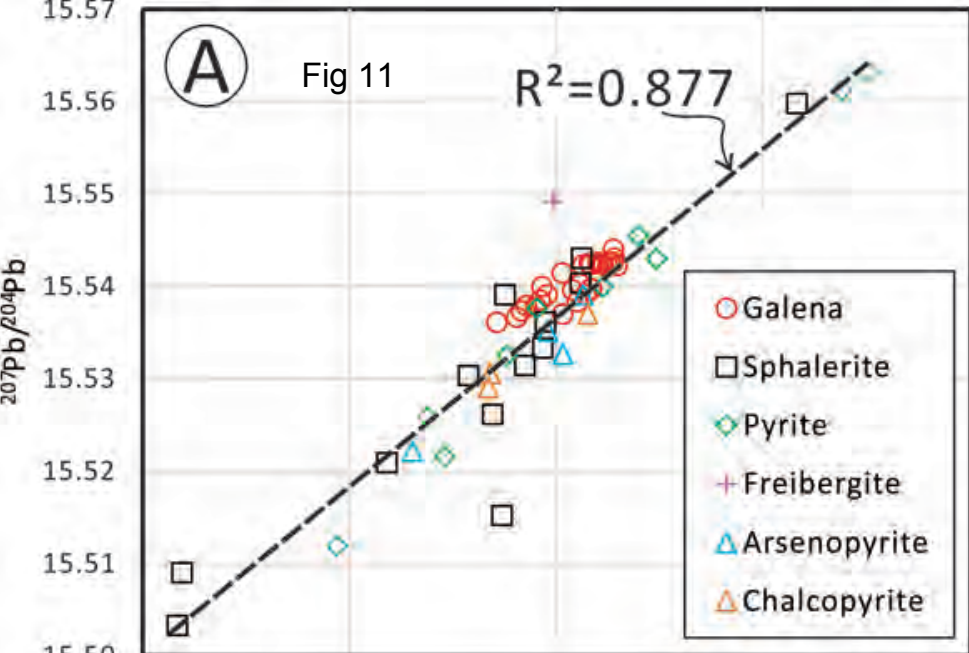




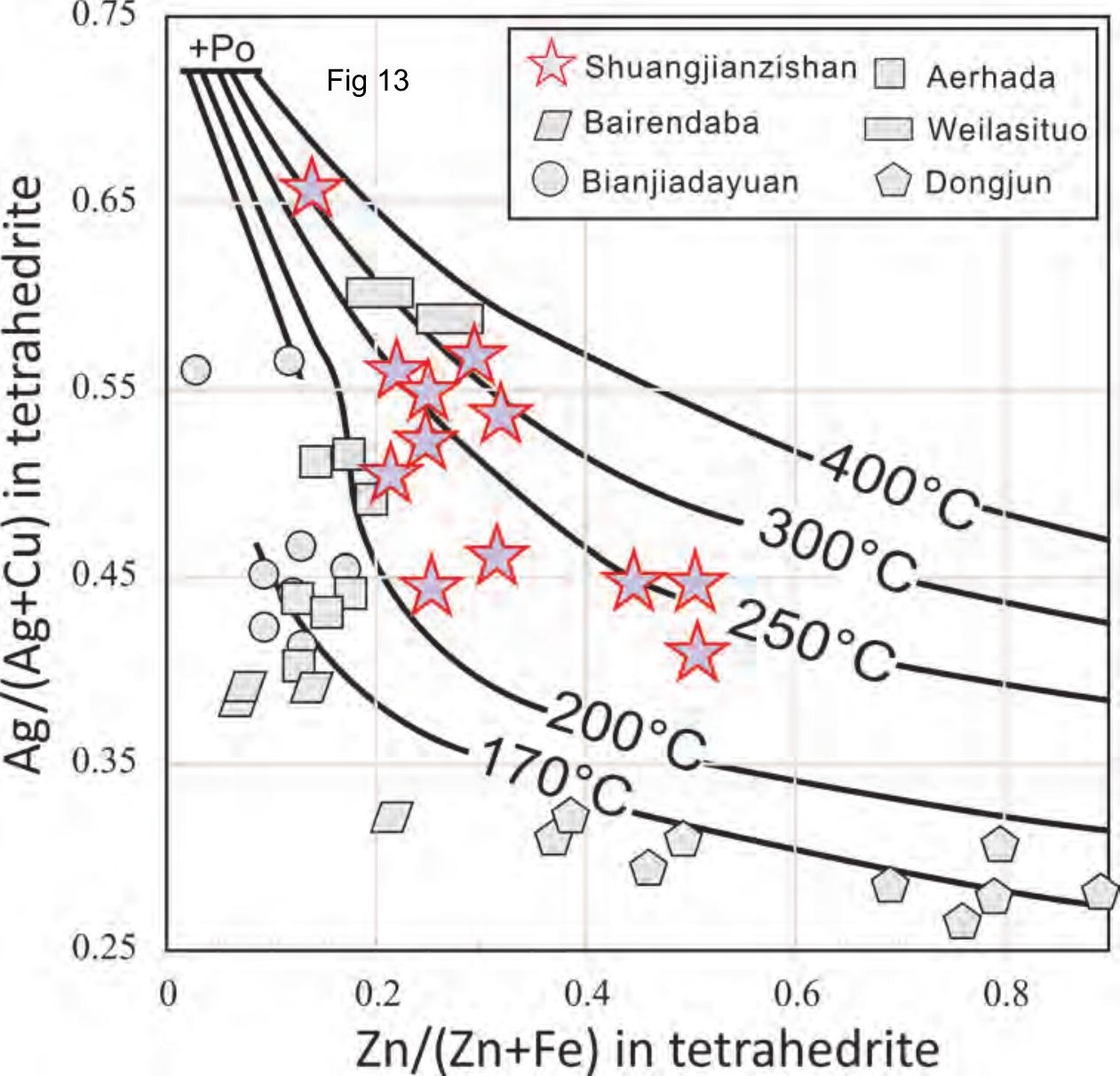



$250^{\circ} \mathrm{C} \quad k \ln |\sec | k f s$

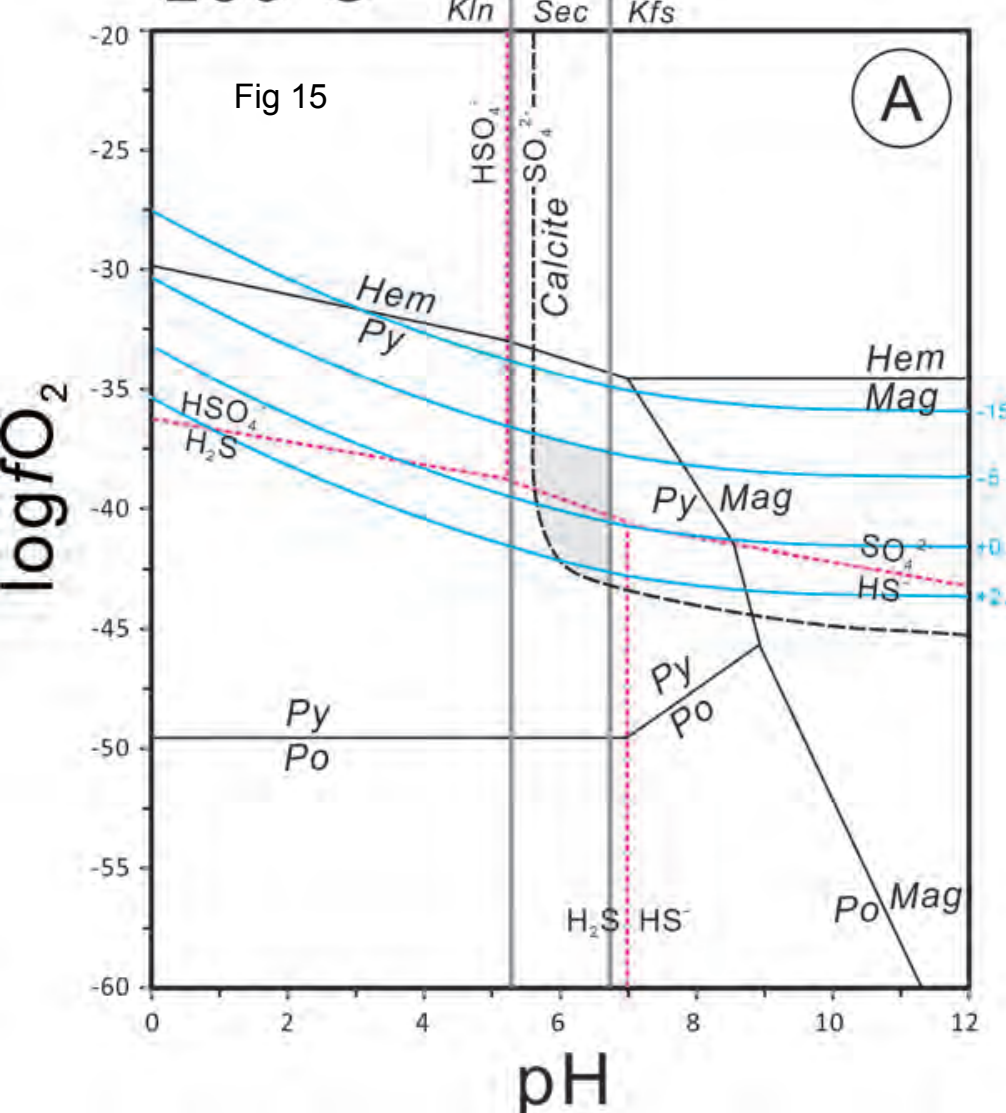

$200^{\circ} \mathrm{C}$






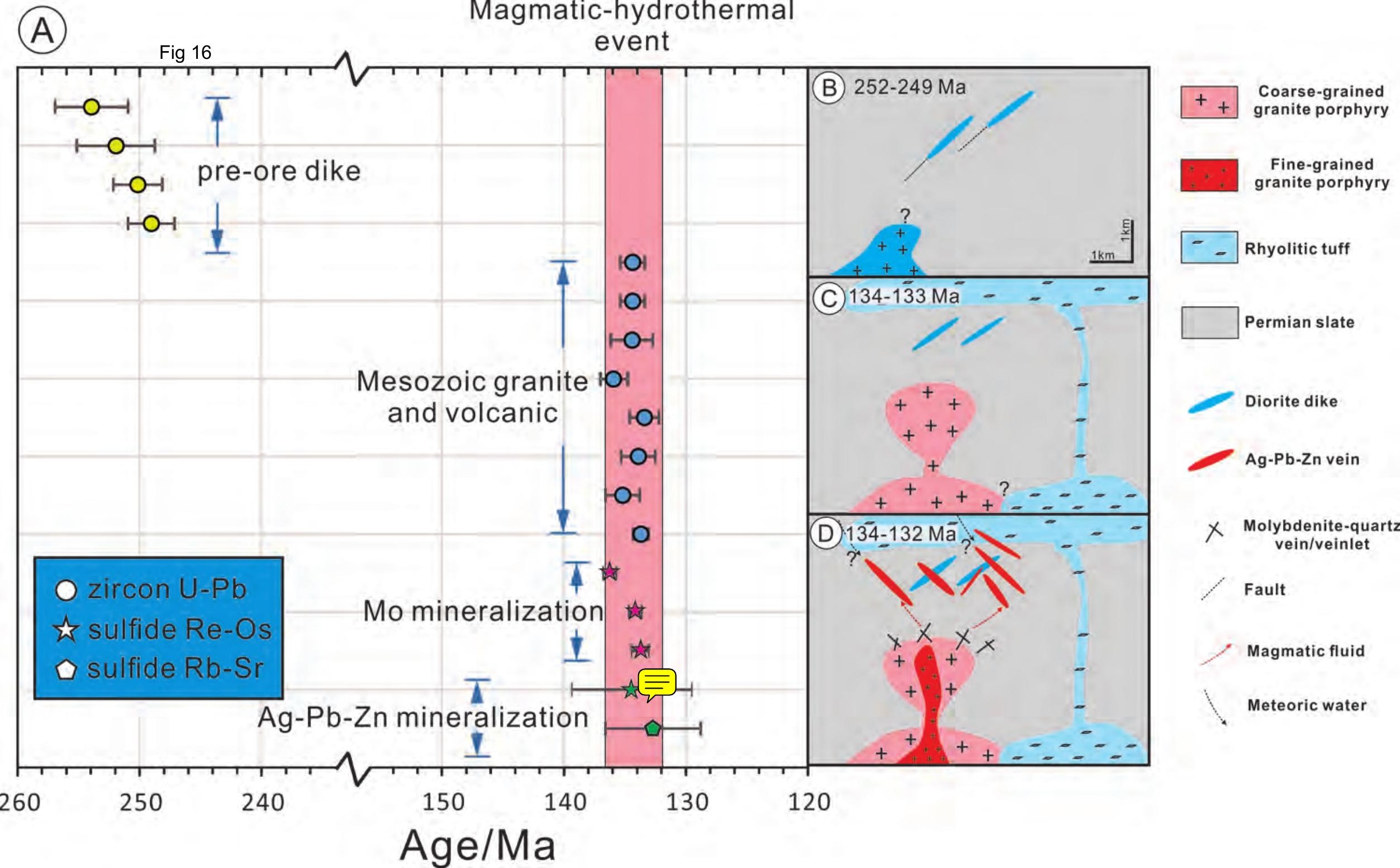




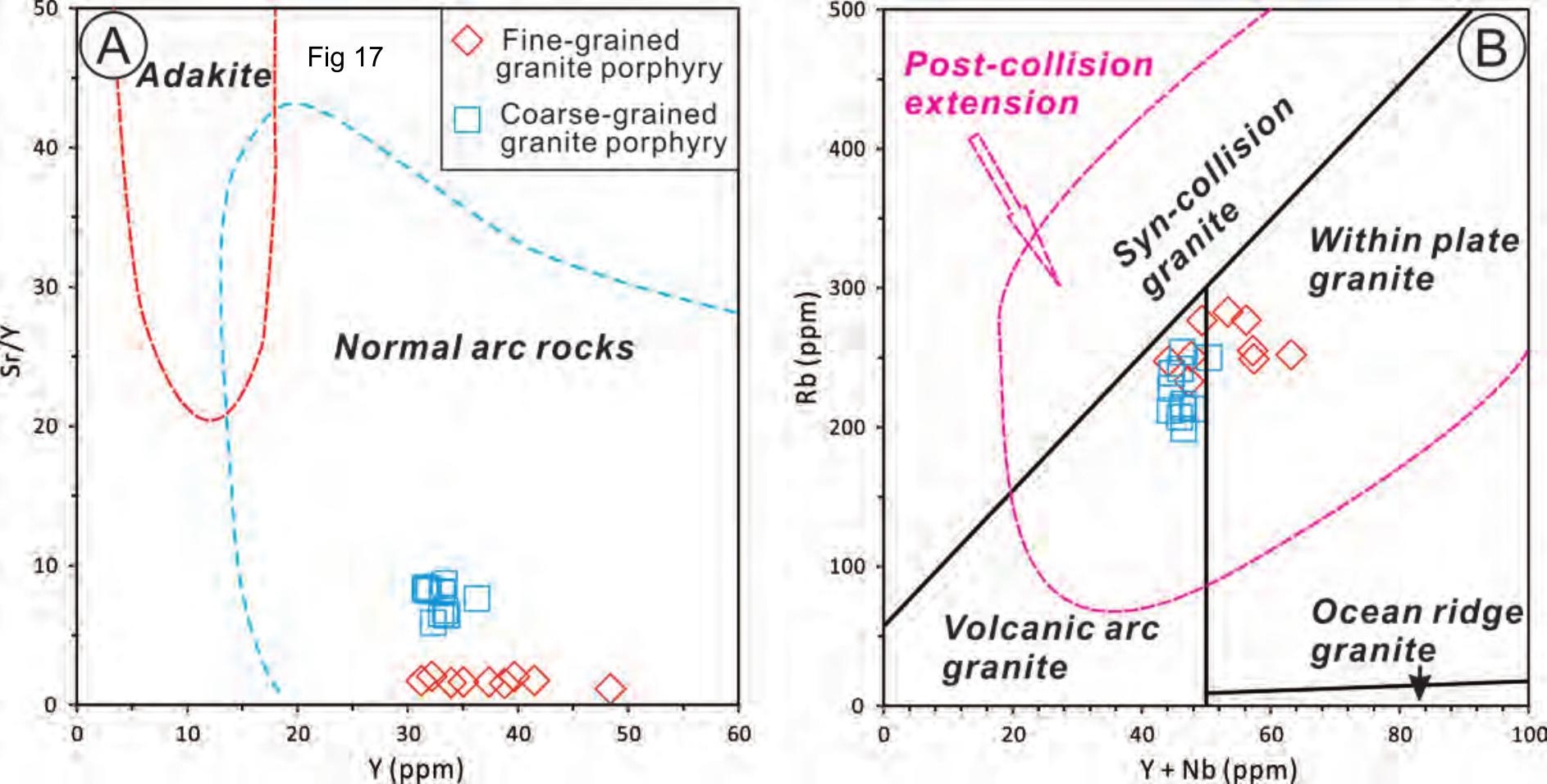


Table 1 Major and trace element concentrations for magmatic rocks in the Shu

\begin{tabular}{|c|c|c|c|c|c|c|c|}
\hline Sample & $17 \mathrm{SJ}-47$ & $17 \mathrm{SJ}-48$ & $17 S J-59$ & $17 \mathrm{SJ}-50$ & $17 \mathrm{SJ}-51$ & $17 \mathrm{SJ}-52$ & $17 \mathrm{SJ}-53$ \\
\hline rock type & \multicolumn{7}{|c|}{ orphyry (fineporphyry (fine § porphyry (fine g)orphyry (fine rphyry (coarssphyry (coars orphyry (coarse } \\
\hline \multicolumn{8}{|l|}{ wt \% } \\
\hline $\mathrm{SiO}_{2}$ & 80.02 & 77.31 & 76.21 & 75.65 & 69.70 & 70.02 & 69.59 \\
\hline $\mathrm{TiO}_{2}$ & 0.11 & 0.13 & 0.12 & 0.13 & 0.38 & 0.41 & 0.40 \\
\hline $\mathrm{Al}_{2} \mathrm{O}_{3}$ & 11.22 & 12.09 & 12.87 & 12.62 & 14.30 & 14.39 & 15.29 \\
\hline $\mathrm{TFe}_{2} \mathrm{O}_{3}$ & 0.81 & 0.95 & 1.12 & 1.05 & 2.85 & 2.93 & 2.85 \\
\hline $\mathrm{MnO}$ & 0.01 & 0.01 & 0.02 & 0.02 & 0.05 & 0.06 & 0.06 \\
\hline $\mathrm{MgO}$ & 0.15 & 0.11 & 0.13 & 0.14 & 0.64 & 0.72 & 0.72 \\
\hline $\mathrm{CaO}$ & 0.15 & 0.19 & 0.65 & 0.35 & 1.56 & 1.51 & 1.71 \\
\hline $\mathrm{Na}_{2} \mathrm{O}$ & 2.15 & 3.45 & 3.72 & 3.51 & 4.11 & 4.08 & 4.58 \\
\hline $\mathrm{K}_{2} \mathrm{O}$ & 4.55 & 4.68 & 4.47 & 4.94 & 4.25 & 4.14 & 4.02 \\
\hline $\mathrm{P}_{2} \mathrm{O}_{5}$ & 0.03 & 0.03 & 0.03 & 0.05 & 0.08 & 0.11 & 0.11 \\
\hline LOI & 0.70 & 0.65 & 0.69 & 0.65 & 1.43 & 1.36 & 0.89 \\
\hline \multicolumn{8}{|l|}{$\mathrm{ppm}$} \\
\hline Sc & 1.10 & 1.06 & 0.93 & 0.99 & 4.39 & 4.33 & 4.04 \\
\hline $\mathrm{Cu}$ & 16.30 & 19.38 & 23.34 & 3.59 & 14.84 & 8.29 & 4.11 \\
\hline $\mathrm{Zn}$ & 30.31 & 31.02 & 30.34 & 27.73 & 60.11 & 64.76 & 55.91 \\
\hline $\mathrm{Ga}$ & 17.62 & 18.61 & 19.88 & 20.41 & 22.96 & 22.57 & 23.26 \\
\hline $\mathrm{Rb}$ & 250.76 & 247.54 & 252.00 & 276.78 & 207.36 & 227.92 & 214.20 \\
\hline $\mathrm{Sr}$ & 57.99 & 54.59 & 56.06 & 55.14 & 261.96 & 267.50 & 291.13 \\
\hline$Y$ & 35.07 & 31.25 & 48.41 & 33.96 & 31.95 & 31.73 & 33.36 \\
\hline $\mathrm{Zr}$ & 101.17 & 105.72 & 171.17 & 125.00 & 207.84 & 196.06 & 227.09 \\
\hline $\mathrm{Nb}$ & 12.61 & 12.93 & 14.78 & 15.39 & 13.97 & 12.83 & 13.05 \\
\hline Sn & 4.86 & 5.00 & 4.53 & 3.25 & 5.98 & 8.30 & 11.78 \\
\hline Cs & 9.45 & 5.88 & 7.26 & 8.14 & 10.39 & 11.69 & 11.35 \\
\hline $\mathrm{Ba}$ & 212.67 & 151.35 & 152.66 & 150.34 & 435.74 & 457.80 & 480.48 \\
\hline La & 21.17 & 24.36 & 27.14 & 25.41 & 30.21 & 31.38 & 24.78 \\
\hline $\mathrm{Ce}$ & 45.74 & 52.70 & 57.77 & 54.03 & 63.89 & 65.03 & 53.53 \\
\hline $\operatorname{Pr}$ & 5.31 & 6.04 & 6.68 & 6.17 & 7.36 & 7.68 & 6.57 \\
\hline $\mathrm{Nd}$ & 18.47 & 21.35 & 22.87 & 21.53 & 27.50 & 27.68 & 24.28 \\
\hline $\mathrm{Sm}$ & 4.14 & 4.69 & 5.44 & 4.72 & 6.18 & 5.93 & 5.52 \\
\hline $\mathrm{Eu}$ & 0.18 & 0.21 & 0.19 & 0.21 & 0.65 & 0.68 & 0.64 \\
\hline $\mathrm{Gd}$ & 3.69 & 4.17 & 5.21 & 4.08 & 5.29 & 5.15 & 4.95 \\
\hline $\mathrm{Tb}$ & 0.74 & 0.71 & 0.95 & 0.75 & 0.86 & 0.86 & 0.82 \\
\hline Dy & 5.01 & 4.78 & 6.74 & 4.94 & 5.50 & 5.30 & 5.39 \\
\hline Ho & 1.03 & 0.93 & 1.40 & 1.03 & 1.03 & 1.01 & 1.01 \\
\hline $\mathrm{Er}$ & 3.47 & 3.03 & 4.69 & 3.36 & 3.22 & 3.15 & 3.27 \\
\hline $\mathrm{Tm}$ & 0.58 & 0.50 & 0.75 & 0.55 & 0.47 & 0.47 & 0.48 \\
\hline $\mathrm{Yb}$ & 4.25 & 3.45 & 5.52 & 4.05 & 3.28 & 3.12 & 3.34 \\
\hline Lu & 0.62 & 0.51 & 0.81 & 0.59 & 0.48 & 0.47 & 0.50 \\
\hline $\mathrm{Hf}$ & 4.34 & 4.41 & 6.51 & 5.38 & 6.86 & 6.28 & 6.80 \\
\hline Ta & 2.16 & 2.05 & 2.41 & 2.62 & 1.55 & 1.32 & 1.47 \\
\hline $\mathrm{Pb}$ & 36.28 & 26.20 & 26.80 & 26.55 & 29.87 & 20.11 & 18.10 \\
\hline Th & 32.40 & 37.34 & 38.83 & 39.43 & 26.04 & 22.86 & 18.04 \\
\hline$U$ & 12.76 & 19.11 & 22.32 & 15.23 & 9.02 & 7.85 & 6.87 \\
\hline
\end{tabular}


angjianzishan ore district

\begin{tabular}{|c|c|c|c|}
\hline $17 \mathrm{SJ}-87$ & $17 \mathrm{SJ}-24$ & $17 \mathrm{SJ}-63$ & $17 \mathrm{SJ}-60$ \\
\hline \multicolumn{2}{|c|}{ trusion (nortl diorite dike } & diorite dike & ryholitic tuff \\
\hline 73.64 & 67.28 & 54.21 & 64.95 \\
\hline 0.18 & 0.59 & 0.90 & 0.58 \\
\hline 14.11 & 16.14 & 14.73 & 15.88 \\
\hline 1.21 & 4.25 & 7.62 & 4.23 \\
\hline 0.02 & 0.14 & 0.19 & 0.09 \\
\hline 0.10 & 1.42 & 4.66 & 1.08 \\
\hline 0.41 & 0.35 & 6.70 & 1.85 \\
\hline 3.26 & 2.32 & 3.00 & 4.60 \\
\hline 4.99 & 4.43 & 3.48 & 3.61 \\
\hline 0.02 & 0.14 & 0.63 & 0.09 \\
\hline 1.14 & 2.63 & 4.06 & 2.15 \\
\hline 3.69 & 5.60 & 25.58 & 6.85 \\
\hline 4.12 & 3.89 & 39.11 & 5.16 \\
\hline 34.59 & 1243.88 & 83.19 & 70.02 \\
\hline 22.66 & 21.52 & 16.62 & 17.32 \\
\hline 157.24 & 122.14 & 85.88 & 74.73 \\
\hline 21.38 & 116.33 & 442.90 & 802.87 \\
\hline 30.97 & 10.39 & 22.90 & 17.74 \\
\hline 381.17 & 224.99 & 123.95 & 196.10 \\
\hline 13.14 & 7.95 & 4.73 & 8.06 \\
\hline 6.04 & 8.27 & 2.23 & 1.52 \\
\hline 5.96 & 14.50 & 0.54 & 2.49 \\
\hline 145.76 & 671.63 & 671.13 & 1239.83 \\
\hline 65.91 & 27.41 & 12.45 & 31.07 \\
\hline 134.56 & 54.62 & 27.58 & 60.58 \\
\hline 15.49 & 6.24 & 3.68 & 6.89 \\
\hline 55.42 & 22.60 & 15.80 & 24.27 \\
\hline 9.76 & 4.14 & 3.79 & 4.27 \\
\hline 0.21 & 0.97 & 1.16 & 1.11 \\
\hline 6.92 & 2.95 & 3.86 & 3.49 \\
\hline 0.99 & 0.34 & 0.63 & 0.52 \\
\hline 6.05 & 2.03 & 3.97 & 3.23 \\
\hline 1.06 & 0.35 & 0.82 & 0.62 \\
\hline 3.20 & 0.97 & 2.43 & 1.83 \\
\hline 0.45 & 0.13 & 0.35 & 0.26 \\
\hline 3.07 & 0.73 & 2.30 & 1.75 \\
\hline 0.45 & 0.12 & 0.35 & 0.27 \\
\hline 10.48 & 5.41 & 3.35 & 5.11 \\
\hline 1.03 & 0.57 & 0.32 & 0.60 \\
\hline 23.37 & 261.24 & 21.57 & 20.63 \\
\hline 22.08 & 10.58 & 3.48 & 9.12 \\
\hline 5.31 & 2.56 & 1.34 & 2.90 \\
\hline
\end{tabular}


Table 2 In situ sulfur isotope results of ore minerals i

\begin{tabular}{|c|c|c|c|c|c|}
\hline Number & Samples & Depth (m) & Ore stage & Minerals & $\delta^{34}$ Svcdt (\%o) \\
\hline 1 & 15SJ-16-Q1-Gn-1 & 230 & II-1 & Gn & -3.41 \\
\hline 2 & 15SJ-16-Q1-Py-2 & 230 & II-1 & Py & -1.11 \\
\hline 3 & 15SJ-16-Q1-Sp-3 & 230 & II-1 & $\mathrm{Sp}$ & -1.45 \\
\hline 4 & 15SJ-16-Q2-Gn-1 & 230 & II-1 & Gn & -4.67 \\
\hline 5 & 15SJ-16-Q2-Sp-2 & 230 & II-1 & $\mathrm{Sp}$ & -1.53 \\
\hline 6 & 15SJ-16-Q2-Apy-3 & 230 & II-1 & Apy & -2.54 \\
\hline 7 & 15SJ-16-Q3-Gn-1 & 230 & II-1 & Gn & -3.40 \\
\hline 8 & 15SJ-16-Q3-Gn-2 & 230 & II-1 & Gn & -3.51 \\
\hline 9 & 15SJ-16-Q3-Sp-3 & 230 & II-1 & Sp & -1.20 \\
\hline 10 & 15SJ-31-Q1-Gn-1 & 150 & II-1 & Gn & -3.64 \\
\hline 11 & 15SJ-31-Q1-Gn-2 & 150 & II-1 & Gn & -3.48 \\
\hline 12 & 15SJ-31-Q1-Frb-3 & 150 & II-2 & $\mathrm{Frb}$ & -1.72 \\
\hline 13 & 15SJ-31-Q1-Frb-4 & 150 & II-2 & Frb & -1.35 \\
\hline 14 & 15SJ-31-Q4-Frb-1 & 150 & II-2 & Frb & -1.18 \\
\hline 15 & 15SJ-31-Q4-Frb-2 & 150 & II-2 & Frb & -0.44 \\
\hline 16 & 15SJ-43-Q1-Gn-1 & 190 & II-1 & Gn & -3.79 \\
\hline 17 & 15SJ-43-Q1-Gn-2 & 190 & II-1 & Gn & -3.53 \\
\hline 18 & 15SJ-43-Q1-Gn-3 & 190 & II-1 & Gn & -3.35 \\
\hline 19 & 15SJ-43-Q1-Gn-4 & 190 & II-1 & Gn & -3.66 \\
\hline 20 & 15SJ-43-Q1-Gn-5 & 190 & II-1 & Gn & -3.22 \\
\hline 21 & 15SJ-43-Q2-Gn-1 & 190 & II-1 & Gn & -4.62 \\
\hline 22 & 15SJ-43-Q2-Gn-2 & 190 & II-1 & Gn & -3.83 \\
\hline 23 & 15SJ-43-Q2-Py-3 & 190 & 1 & Py & -1.65 \\
\hline 24 & 15SJ-43-Q2-Sp-4 & 190 & II-1 & Sp & -1.07 \\
\hline 25 & 15SJ-51-Q1-Gn-1 & 230 & II-1 & Gn & -3.14 \\
\hline 26 & 15SJ-51-Q1-Gn-2 & 230 & II-1 & Gn & -3.11 \\
\hline 27 & 15SJ-51-Q1-Gn-3 & 230 & II-1 & Gn & -4.51 \\
\hline 28 & 15SJ-51-Q1-Sp-4 & 230 & II-1 & Sp & -0.79 \\
\hline 29 & 15SJ-51-Q1-Sp-5 & 230 & II-1 & Sp & -2.39 \\
\hline 30 & 15SJ-51-Q2-Gn-1 & 230 & II-1 & Gn & -3.42 \\
\hline 31 & 15SJ-51-Q2-Gn-2 & 230 & II-1 & Gn & -4.10 \\
\hline 32 & 15SJ-51-Q2-Sp-3 & 230 & II-1 & Sp & -1.21 \\
\hline 33 & 15SJ-51-Q2-Sp-4 & 230 & II-1 & Sp & -2.76 \\
\hline 34 & 15SJ-84-Q1-Gn-1 & 110 & II-1 & Gn & -3.68 \\
\hline 35 & 15SJ-84-Q1-Py-2 & 110 & II-1 & Py & -0.87 \\
\hline 36 & 15SJ-84-Q1-Sp-3 & 110 & II-1 & Sp & -0.62 \\
\hline 37 & 15SJ-84-Q2-Gn-1 & 110 & II-1 & Gn & -3.78 \\
\hline 38 & 15SJ-84-Q2-Gn-2 & 110 & II-1 & Gn & -3.96 \\
\hline 39 & 15SJ-84-Q2-Py-3 & 110 & $\mathrm{II}-1$ & Py & -1.27 \\
\hline
\end{tabular}


in the Shuangjianishan Ag-Pb-Zn deposit

\begin{tabular}{|c|c|c|c|c|c|}
\hline Number & Samples & Depth $(m)$ & Ore stage & Minerals & $\delta^{34}$ Svcdt (\%o) \\
\hline 40 & 15SJ-84-Q3-Apy-1 & 110 & $\mathrm{II}-1$ & Apy & -1.36 \\
\hline 41 & 15SJ-84-Q4-Apy-1 & 110 & II-1 & Apy & -1.08 \\
\hline 42 & 15SJ-94-Q1-Pyr-1 & 110 & II-2 & Pyr & 2.13 \\
\hline 43 & 15SJ-94-Q1-Pyr-2 & 110 & $\mathrm{II}-2$ & Pyr & 2.44 \\
\hline 44 & 15SJ-94-Q1-Pyr-3 & 110 & II-2 & Pyr & 1.41 \\
\hline 45 & 15SJ-94-Q1-Caf-4 & 110 & $\mathrm{II}-2$ & Caf & -0.65 \\
\hline 46 & 15SJ-94-Q1-Gn-5 & 110 & II-1 & Gn & -3.85 \\
\hline 47 & 15SJ-94-Q2-Gn-1 & 110 & II-1 & Gn & -3.47 \\
\hline 48 & 15SJ-94-Q2-Caf-2 & 110 & $\mathrm{II}-2$ & Caf & -1.94 \\
\hline 49 & 15SJ-94-Q2-Сср-3 & 110 & II-1 & Ccp & -1.86 \\
\hline 50 & 15SJ-94-Q3-Caf-1 & 110 & $\|-2$ & Caf & -1.35 \\
\hline 51 & 15SJ-94-Q4-Caf-1 & 110 & II-2 & Caf & -1.87 \\
\hline 52 & 15SJ-94-Q4-Caf-2 & 110 & II-2 & Caf & -1.91 \\
\hline 53 & 15SJ-94-Q5-Caf-1 & 110 & II-2 & Caf & -1.53 \\
\hline 54 & 15SJ-94-Q5-Sp-2 & 110 & II-1 & $\mathrm{Sp}$ & 0.27 \\
\hline 55 & 15SJ-94-Q5-Py-3 & 110 & II-1 & Py & -1.80 \\
\hline 56 & 15SJ-94-Q5-Gn-4 & 110 & II-1 & Gn & -3.25 \\
\hline 57 & 15SJ-97-Q1-Py-1 & 110 & 1 & Py & -1.27 \\
\hline 58 & 15SJ-97-Q1-Py-2 & 110 & 1 & Py & -1.19 \\
\hline 59 & 15SJ-97-Q1-Сcp-3 & 110 & II-1 & Ccp & -1.42 \\
\hline 60 & 15SJ-97-Q1-Сcp-4 & 110 & II-1 & Ccp & -1.71 \\
\hline 61 & 15SJ-97-Q1-Sp-5 & 110 & II-1 & Sp & -1.17 \\
\hline 62 & 15SJ-97-Q2-Сcp-1 & 110 & II-1 & Ccp & -1.13 \\
\hline 63 & 15SJ-97-Q2-Gn-2 & 110 & II-1 & Gn & -1.54 \\
\hline 64 & 15SJ-97-Q2-Py-3 & 110 & I & Py & -1.22 \\
\hline 65 & 15SJ-97-Q2-Sp-4 & 110 & II-1 & $\mathrm{Sp}$ & -0.88 \\
\hline 66 & 15SJ-99-Q1-Apy-1 & 110 & II-1 & Apy & -0.39 \\
\hline 67 & 15SJ-99-Q1-Sp-2 & 110 & II-1 & Sp & -0.91 \\
\hline 68 & 15SJ-99-Q1-Gn-3 & 110 & II-1 & Gn & -3.49 \\
\hline 69 & 15SJ-99-Q1-Сср-4 & 110 & II-1 & Ccp & -1.78 \\
\hline 70 & 15SJ-99-Q2-Gn-1 & 110 & II-1 & Gn & -2.74 \\
\hline 71 & 15SJ-99-Q2-Gn-2 & 110 & II-1 & Gn & -2.57 \\
\hline 72 & 15SJ-104-Q1-Py-1 & $190-210$ & II-1 & Py & -0.92 \\
\hline 73 & 15SJ-104-Q1-Sp-2 & $190-210$ & II-1 & $\mathrm{Sp}$ & -2.47 \\
\hline 74 & 15SJ-104-Q1-Gn-3 & $190-210$ & II-1 & Gn & -4.57 \\
\hline 75 & 15SJ-104-Q2-Sp-1 & $190-210$ & II-1 & Sp & -2.95 \\
\hline 76 & 15SJ-104-Q2-Gn-2 & $190-210$ & II-1 & Gn & -4.18 \\
\hline 77 & 15SJ-104-Q2-Py-3 & $190-210$ & 1 & Py & -1.36 \\
\hline
\end{tabular}

r-pyrargyrite; Sp-sphalerite. 
Table 3 In situ lead isotope results of ore minerals in the Shuangji

\begin{tabular}{|c|c|c|c|c|c|}
\hline Number & Samples & Depth $(\mathrm{m})$ & Ore stage & Minerals & ${ }^{206} \mathrm{~Pb} /{ }^{204} \mathrm{~Pb}$ \\
\hline 1 & 15SJ-104-q1-py-1 & $190-210$ & 1 & Pyrite & 18.308 \\
\hline 2 & 15SJ-104-q1-sp-1 & $190-210$ & II-1 & Sphalerite & 18.264 \\
\hline 3 & 15SJ-104-q1-ару-1 & $190-210$ & II-1 & Arsenopyrite & 18.279 \\
\hline 4 & 15SJ-104-q2-gn-3 & $190-210$ & II-1 & Galena & 18.283 \\
\hline 5 & 15SJ-104-q2-py-1 & $190-210$ & II-1 & Pyrite & 18.284 \\
\hline 6 & $15 S J-104-q 2-s p-1$ & $190-210$ & II-1 & Sphalerite & 18.244 \\
\hline 7 & 15SJ-16-q1-gn-1 & 230 & II-1 & Galena & 18.282 \\
\hline 8 & 15SJ-16-q1-py-1 & 230 & II-1 & Pyrite & 18.269 \\
\hline 9 & 15SJ-16-q1-sp-1 & 230 & II-1 & Sphalerite & 18.303 \\
\hline 10 & 15SJ-16-q2-gn-1 & 230 & II-1 & Galena & 18.283 \\
\hline 11 & 15SJ-16-q2-sp-1 & 230 & II-1 & Sphalerite & 18.279 \\
\hline 12 & 15SJ-16-q2-apy-1 & 230 & II-1 & Arsenopyrite & 18.281 \\
\hline 13 & 15SJ-16-q3-gn-1 & 230 & II-1 & Galena & 18.283 \\
\hline 14 & 15SJ-16-q3-gn-2 & 230 & II-1 & Galena & 18.281 \\
\hline 15 & 15SJ-16-q3-sp-1 & 230 & II-1 & Sphalerite & 18.275 \\
\hline 16 & 15SJ-31-q1-frb-1 & 150 & II-2 & Freibergite & 18.280 \\
\hline 17 & 15SJ-31-q4-gn-1 & 150 & II-1 & Galena & 18.285 \\
\hline 18 & 15SJ-31-q4-gn-2 & 150 & II-1 & Galena & 18.284 \\
\hline 19 & 15SJ-43-q1-gn-1 & 190 & II-1 & Galena & 18.277 \\
\hline 20 & 15SJ-43-q1-gn-2 & 190 & II-1 & Galena & 18.277 \\
\hline 21 & 15SJ-43-q1-gn-3 & 190 & II-1 & Galena & 18.276 \\
\hline 22 & 15SJ-43-q1-gn-4 & 190 & II-1 & Galena & 18.285 \\
\hline 23 & 15SJ-43-q1-gn-5 & 190 & II-1 & Galena & 18.286 \\
\hline 24 & 15SJ-43-q2-gn-1 & 190 & II-1 & Galena & 18.274 \\
\hline 25 & 15SJ-43-q2-gn-2 & 190 & II-1 & Galena & 18.278 \\
\hline 26 & $15 S J-43-q 2-p y-1$ & 190 & II-1 & Pyrite & 18.290 \\
\hline 27 & $15 S J-43-q 2-s p-1$ & 190 & II-1 & Sphalerite & 18.274 \\
\hline 28 & 15SJ-51-q1-gn-1 & 230 & II-1 & Galena & 18.286 \\
\hline 29 & 15SJ-51-q1-gn-2 & 230 & II-1 & Galena & 18.285 \\
\hline 30 & 15SJ-51-q1-gn-3 & 230 & II-1 & Galena & 18.282 \\
\hline 31 & 15SJ-51-q1-sp-1 & 230 & II-1 & Sphalerite & 18.282 \\
\hline 32 & 15SJ-51-q1-sp-2 & 230 & II-1 & Sphalerite & 18.271 \\
\hline 33 & 15SJ-51-q2-gn-1 & 230 & II-1 & Galena & 18.282 \\
\hline 34 & 15SJ-51-q2-gn-2 & 230 & II-1 & Galena & 18.283 \\
\hline 35 & 15SJ-51-q2-sp-1 & 230 & II-1 & Sphalerite & 18.282 \\
\hline 36 & $15 S J-51-q 2-s p-2$ & 230 & II-1 & Sphalerite & 18.243 \\
\hline 37 & 15SJ-84-q1-gn-1 & 110 & II-1 & Galena & 18.284 \\
\hline 38 & 15SJ-84-q1-py-1 & 110 & I & Pyrite & 18.310 \\
\hline 39 & 15SJ-84-q2-gn-1 & 110 & II-1 & Galena & 18.286 \\
\hline 40 & 15SJ-84-q2-gn-2 & 110 & II-1 & Galena & 18.285 \\
\hline 41 & 15SJ-84-q2-py-1 & 110 & I & Pyrite & 18.288 \\
\hline 42 & 15SJ-84-q3-apy-1 & 110 & II-1 & Arsenopyrite & 18.266 \\
\hline 43 & 15SJ-84-q4-apy-1 & 110 & II-1 & Arsenopyrite & 18.283 \\
\hline 44 & 15SJ-94-q1-gn-1 & 110 & II-1 & Galena & 18.283 \\
\hline 45 & 15SJ-94-q2-gn-1 & 110 & II-1 & Galena & 18.283 \\
\hline 46 & 15SJ-97-q1-cсp-1 & 110 & II-1 & Chalcopyrite & 18.273 \\
\hline 47 & 15SJ-97-q1-сср-2 & 110 & II-1 & Chalcopyrite & 18.274 \\
\hline 48 & 15SJ-97-q1-py-1 & 110 & I & Pyrite & 18.268 \\
\hline 49 & 15SJ-97-q1-py-2 & 110 & I & Pyrite & 18.259 \\
\hline
\end{tabular}




\begin{tabular}{|c|c|c|c|c|c|}
\hline 50 & 15SJ-97-q1-sp-1 & 110 & $\|-1$ & Sphalerite & 18.277 \\
\hline 51 & 15SJ-97-q2-сcp-1 & 110 & $\|-1$ & Chalcopyrite & 18.283 \\
\hline 52 & 15SJ-97-q2-gn-1 & 110 & II-1 & Galena & 18.279 \\
\hline 53 & 15SJ-97-q2-py-1 & 110 & I & Pyrite & 18.275 \\
\hline 54 & 15SJ-97-q2-sp-1 & 110 & $\|-1$ & Sphalerite & 18.279 \\
\hline 55 & 15SJ-99-q1-gn-1 & 110 & II-1 & Galena & 18.279 \\
\hline 56 & 15SJ-99-q1-py-1 & 110 & I & Pyrite & 18.278 \\
\hline 57 & 15SJ-99-q1-sp-1 & 110 & $\|-1$ & Sphalerite & 18.275 \\
\hline 58 & 15SJ-99-q2-gn-1 & 110 & II-1 & Galena & 18.278 \\
\hline 59 & 15SJ-99-q2-gn-1 & 110 & II-1 & Galena & 18.281 \\
\hline
\end{tabular}


ianzishan $\mathrm{Ag}-\mathrm{Pb}-\mathrm{Zn}$ deposit

\begin{tabular}{|c|c|c|c|c|}
\hline $1 \sigma$ & ${ }^{207} \mathrm{~Pb} /{ }^{204} \mathrm{~Pb}$ & $1 \sigma$ & ${ }^{208} \mathrm{~Pb} /{ }^{204} \mathrm{~Pb}$ & $1 \sigma$ \\
\hline 0.020 & 15.561 & 0.018 & 38.203 & 0.042 \\
\hline 0.026 & 15.521 & 0.023 & 38.105 & 0.056 \\
\hline 0.003 & 15.535 & 0.003 & 38.142 & 0.009 \\
\hline 0.002 & 15.542 & 0.002 & 38.163 & 0.006 \\
\hline 0.006 & 15.540 & 0.005 & 38.155 & 0.013 \\
\hline 0.015 & 15.509 & 0.013 & 38.073 & 0.031 \\
\hline 0.002 & 15.540 & 0.002 & 38.148 & 0.006 \\
\hline 0.009 & 15.522 & 0.008 & 38.062 & 0.022 \\
\hline 0.004 & 15.560 & 0.004 & 38.194 & 0.012 \\
\hline 0.002 & 15.539 & 0.002 & 38.146 & 0.005 \\
\hline 0.006 & 15.533 & 0.005 & 38.128 & 0.015 \\
\hline 0.004 & 15.533 & 0.004 & 38.123 & 0.010 \\
\hline 0.002 & 15.540 & 0.002 & 38.150 & 0.006 \\
\hline 0.002 & 15.537 & 0.002 & 38.142 & 0.007 \\
\hline 0.013 & 15.515 & 0.012 & 38.116 & 0.029 \\
\hline 0.010 & 15.549 & 0.010 & 38.166 & 0.032 \\
\hline 0.002 & 15.542 & 0.002 & 38.158 & 0.007 \\
\hline 0.002 & 15.542 & 0.002 & 38.156 & 0.007 \\
\hline 0.002 & 15.537 & 0.002 & 38.151 & 0.006 \\
\hline 0.002 & 15.538 & 0.002 & 38.152 & 0.006 \\
\hline 0.003 & 15.537 & 0.003 & 38.148 & 0.008 \\
\hline 0.002 & 15.542 & 0.002 & 38.159 & 0.006 \\
\hline 0.002 & 15.543 & 0.002 & 38.157 & 0.006 \\
\hline 0.002 & 15.536 & 0.002 & 38.144 & 0.007 \\
\hline 0.002 & 15.538 & 0.003 & 38.152 & 0.007 \\
\hline 0.004 & 15.543 & 0.004 & 38.159 & 0.011 \\
\hline 0.007 & 15.526 & 0.006 & 38.096 & 0.017 \\
\hline 0.002 & 15.544 & 0.002 & 38.164 & 0.007 \\
\hline 0.002 & 15.542 & 0.002 & 38.157 & 0.005 \\
\hline 0.002 & 15.540 & 0.002 & 38.153 & 0.006 \\
\hline 0.026 & 15.543 & 0.022 & 38.169 & 0.055 \\
\hline 0.005 & 15.530 & 0.005 & 38.127 & 0.013 \\
\hline 0.002 & 15.538 & 0.002 & 38.146 & 0.006 \\
\hline 0.002 & 15.540 & 0.002 & 38.151 & 0.005 \\
\hline 0.002 & 15.540 & 0.002 & 38.154 & 0.006 \\
\hline 0.015 & 15.503 & 0.013 & 38.053 & 0.032 \\
\hline 0.002 & 15.543 & 0.002 & 38.163 & 0.006 \\
\hline 0.016 & 15.563 & 0.014 & 38.197 & 0.035 \\
\hline 0.002 & 15.542 & 0.002 & 38.156 & 0.006 \\
\hline 0.003 & 15.543 & 0.003 & 38.161 & 0.008 \\
\hline 0.005 & 15.545 & 0.005 & 38.167 & 0.012 \\
\hline 0.004 & 15.522 & 0.003 & 38.103 & 0.010 \\
\hline 0.002 & 15.539 & 0.002 & 38.147 & 0.007 \\
\hline 0.003 & 15.542 & 0.003 & 38.164 & 0.008 \\
\hline 0.002 & 15.542 & 0.002 & 38.159 & 0.006 \\
\hline 0.006 & 15.529 & 0.006 & 38.128 & 0.020 \\
\hline 0.006 & 15.531 & 0.006 & 38.127 & 0.015 \\
\hline 0.004 & 15.526 & 0.004 & 38.114 & 0.011 \\
\hline 0.010 & 15.512 & 0.009 & 38.061 & 0.023 \\
\hline
\end{tabular}




\begin{tabular}{lllll}
0.004 & 15.531 & 0.004 & 38.123 & 0.010 \\
0.008 & 15.537 & 0.007 & 38.142 & 0.020 \\
0.002 & 15.539 & 0.002 & 38.154 & 0.007 \\
0.002 & 15.532 & 0.003 & 38.136 & 0.008 \\
0.006 & 15.536 & 0.006 & 38.146 & 0.016 \\
0.003 & 15.540 & 0.003 & 38.160 & 0.008 \\
0.001 & 15.538 & 0.002 & 38.150 & 0.005 \\
0.007 & 15.539 & 0.006 & 38.140 & 0.016 \\
0.002 & 15.538 & 0.002 & 38.150 & 0.007 \\
0.002 & 15.541 & 0.003 & 38.162 & 0.007 \\
\hline
\end{tabular}


Table 4 Molybdenite Re-Os results of the Shuangjianzishan Ag-Pb.

\begin{tabular}{|cccccccc}
\hline Sample & wt $(\mathbf{g})$ & $\mathbf{R e}(\mathbf{p p m})$ & $\mathbf{\mathbf { 2 0 } \sigma}$ & ${ }^{\mathbf{1 8 7}} \mathbf{R e}(\mathbf{p p m})$ & $\mathbf{\pm 2 \sigma}$ & ${ }^{\mathbf{1 8 7}}$ Os $(\mathbf{p p b})$ & $\mathbf{\pm 2 \sigma}$ \\
\hline 17SJ-34 & 0.021 & 2.640 & 0.012 & 1.659 & 0.008 & 3.773 & 0.015 \\
17SJ-35 & 0.061 & 0.119 & 0.001 & 0.075 & 0.001 & 0.167 & 0.001 \\
17SJ-41 & 0.059 & 1.994 & 0.008 & 1.253 & 0.005 & 2.805 & 0.009 \\
\hline
\end{tabular}

ancertainty including only mass spectrometry uncertainty

buncertainty including all sources of analytical uncertainty

${ }^{c}$ uncertainty including all sources of analytical uncertainty plus decay constant 
-Zn deposit

\begin{tabular}{cccc}
\hline Age $(\mathbf{M a})$ & $\mathbf{\mathbf { 2 } \mathbf { \sigma } ^ { \mathbf { a } }}$ & $\mathbf{\mathbf { 2 } \mathbf { 2 } ^ { \mathbf { b } }}$ & $\mathbf{\mathbf { 2 } \mathbf { \sigma } ^ { \mathbf { c } }}$ \\
\hline 136.31 & 0.15 & 0.75 & 0.87 \\
133.69 & 0.01 & 1.13 & 1.20 \\
134.19 & 0.12 & 0.66 & 0.78 \\
\hline
\end{tabular}


Table 5 Pyrite Re-Os

\begin{tabular}{|cccccccccc}
\hline Samples & $\mathbf{R e}(\mathbf{p p b})$ & $\mathbf{\pm 2 \sigma}$ & ${ }^{187} \operatorname{Re}(\mathbf{p p b})$ & $\mathbf{\pm 2 \sigma}$ & Total Os (ppt) & $\mathbf{\pm 2 \sigma}$ & ${ }^{192} \mathbf{O s}(\mathbf{p p t})$ & $\mathbf{\pm 2 \sigma}$ & ${ }^{187} \mathbf{O s}^{\mathrm{r}}(\mathbf{p p t})$ \\
\hline $15 \mathrm{SJ}-10$ & 0.262 & 0.001 & 0.164 & 0.001 & 2.198 & 0.069 & 0.670 & 0.041 & 0.371 \\
$15 \mathrm{SJ}-16$ & 0.520 & 0.003 & 0.327 & 0.002 & 1.446 & 0.782 & 0.164 & 0.085 & 0.736 \\
$17 \mathrm{SJ}-26$ & 0.886 & 0.003 & 0.557 & 0.002 & 13.082 & 0.153 & 3.546 & 0.065 & 1.253 \\
$15 \mathrm{SJ}-114$ & 1.077 & 0.004 & 0.677 & 0.002 & 1.483 & 1.252 & 0.061 & 0.040 & 1.317 \\
\hline
\end{tabular}

Note: The initial ${ }^{187} \mathrm{Os} /{ }^{188} \mathrm{Os}\left(\mathrm{Os}_{\mathrm{i}}\right)$ values, with the exception of sample $15 \mathrm{SJ}-114$, is the composition necessary to de uncertainty correlation factor (rho) is applied to assess the degree of correlation between ${ }^{187} \mathrm{Re} /{ }^{188}$ Os and ${ }^{187}$ Os $/{ }^{188}$ Os 
data of the Shuangjianzishan Ag-Pb-Zn deposit

\begin{tabular}{ccccccccc}
\hline $\mathbf{\pm 2} \boldsymbol{\sigma}$ & ${ }^{18} \mathbf{O s}^{\mathrm{r}} \%$ & ${ }^{187} \mathrm{Re} /{ }^{188}$ Os & $\mathbf{\pm 2 \sigma}$ & ${ }^{187}$ Os $/{ }^{188}$ Os & $\mathbf{\pm 2 \sigma}$ & rho & \% Re blank & \% $^{187}$ Os blank \\
\hline 0.028 & 60.7 & 776.4 & 48.0 & 2.8 & 0.2 & 0.98 & 2.2 & 0.9 \\
0.170 & 69.3 & 6309.3 & 3269.9 & 20.4 & 10.6 & 1.00 & 2.3 & 1.1 \\
0.146 & 27.0 & 496.9 & 9.2 & 4.1 & 0.1 & 0.78 & 0.6 & 0.1 \\
0.041 & 99.3 & 34959.9 & 23095.1 & 69.0 & 45.6 & 1.00 & 0.5 & 0.4 \\
\hline
\end{tabular}

termine ${ }^{187} \mathrm{Os}^{\mathrm{r}}$ to yield a Re-Os date be broadly similar to that determined from the molybdenite Re-Os dates ratios. 


\begin{tabular}{ccc}
\hline${ }^{188}$ Os blank & Os $_{\mathrm{i}}$ (ppt) & Age (Ma) \\
\hline 10.9 & 1.09 & 134.5 \\
50.8 & 6.16 & 135.6 \\
2.2 & 3.02 & 135.0 \\
56.9 & - & 118.1 \\
\hline
\end{tabular}

(Table 4), see text for full discussion; 

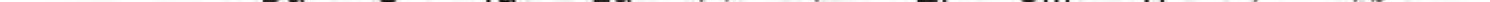





Table A1 Electron microprobe results of sulfide

\begin{tabular}{|c|c|c|c|c|c|c|c|}
\hline No. & Sample & Minerals & $\mathrm{Se}$ & As & $\mathrm{Zn}$ & $\mathrm{S}$ & $\mathrm{Sb}$ \\
\hline 1 & 15SJ-121-Q4-01 & Galena & 0.05 & bd & $\mathrm{bd}$ & 13.24 & 0.04 \\
\hline 2 & 15SJ-121-Q4-02 & Galena & $b d$ & $b d$ & 0.02 & 13.15 & $b d$ \\
\hline 3 & 15SJ-121-Q6-02 & Galena & bd & $b d$ & 0.05 & 13.52 & $b d$ \\
\hline 4 & 15SSJ-73-Q3-1 & Sphalerite & $b d$ & 0.28 & 52.51 & 33.45 & 0.01 \\
\hline 5 & 15SSJ-73-Q6-2 & Sphalerite & $b d$ & $b d$ & 48.15 & 33.80 & $b d$ \\
\hline 6 & 15SSJ-73-Q3-2 & Pyrite & $b d$ & $b d$ & $b d$ & 39.73 & $b d$ \\
\hline 7 & 15SSJ-73-Q5-1 & Pyrite & $b d$ & 0.10 & bd & 39.63 & 0.01 \\
\hline 8 & 15SSJ-73-Q6-1 & Pyrite & $b d$ & 0.01 & 0.13 & 39.98 & 0.04 \\
\hline 9 & 15SSJ-59-Q4-2 & Chalcopyrite & $b d$ & bd & 0.15 & 34.41 & bd \\
\hline 10 & 15SJ-61-Q5-06 & Chalcopyrite & $b d$ & 0.03 & 0.01 & 34.47 & 0.02 \\
\hline 11 & 15SJ-56-Q1-01 & Pyrargyrite & $b d$ & 0.59 & $b d$ & 17.35 & 20.72 \\
\hline 12 & 15SJ-56-Q1-02 & Pyrargyrite & bd & 0.66 & $b d$ & 17.36 & 21.04 \\
\hline 13 & $15 S J-92-2-1$ & Pyrargyrite & $b d$ & 0.27 & 0.09 & 17.76 & 17.58 \\
\hline 14 & $15 S J-94-2$ & Pyrargyrite & $b d$ & 0.45 & 0.01 & 18.01 & 22.93 \\
\hline 15 & $15 S J-92-3-1$ & Pyrargyrite & $b d$ & 0.27 & 0.15 & 17.25 & 16.45 \\
\hline 16 & 15SJ-61-Q5-03 & Argentite & $b d$ & 0.37 & bd & 13.14 & 7.32 \\
\hline 17 & 15SJ-61-Q5-04 & Argentite & $b d$ & 0.23 & $b d$ & 11.33 & 7.57 \\
\hline 18 & 15SSJ-44-Q3-1 & Argentite & 2.51 & 0.46 & bd & 13.20 & 9.14 \\
\hline 19 & 15SSJ-44-Q3-2 & Argentite & 2.37 & 0.46 & bd & 14.29 & 9.42 \\
\hline 20 & 15SJ-56-Q2-04 & Freibergite & $b d$ & 1.06 & 3.23 & 19.97 & 21.64 \\
\hline 21 & 15SJ-56-Q2-04 & Freibergite & $b d$ & 0.86 & 2.99 & 19.60 & 22.15 \\
\hline 22 & 15SSJ-57-Q8-1 & Freibergite & $b d$ & 1.11 & 0.73 & 22.34 & 25.50 \\
\hline 23 & 15SJ-57-Q8-02 & Freibergite & $b d$ & 1.04 & 0.75 & 22.67 & 24.54 \\
\hline 24 & 15SJ-57-Q8-03 & Freibergite & $b d$ & 0.95 & 0.75 & 22.76 & 24.62 \\
\hline 25 & 15SSJ-95-Q3-2 & Freibergite & $b d$ & 1.20 & 0.99 & 22.07 & 24.89 \\
\hline 26 & 15SSJ-95-Q3-2 & Freibergite & $b d$ & 1.18 & 0.85 & 22.14 & 24.98 \\
\hline 27 & 15SJ-57-Q2-04 & Stephanite & 3.22 & 0.88 & $b d$ & 12.83 & 8.31 \\
\hline 28 & 15SJ-56-Q2-02 & Stephanite & 0.09 & 1.48 & $b d$ & 15.60 & 8.43 \\
\hline 29 & 15SJ-56-Q3-02 & Polybasite & 0.87 & 0.52 & $b d$ & 14.35 & 9.15 \\
\hline 30 & 15SJ-56-Q3-01 & Polybasite & 0.82 & 0.26 & $b d$ & 12.16 & 7.79 \\
\hline 31 & 15SSJ-61-Q3-1 & Canfieldite & 6.09 & $b d$ & $b d$ & 15.09 & $b d$ \\
\hline 32 & 15SJ-61-Q3-02 & Canfieldite & 7.03 & bd & $b d$ & 14.57 & $b d$ \\
\hline 33 & 15SJ-61-Q3-04 & Canfieldite & 5.75 & $b d$ & $b d$ & 15.43 & $b d$ \\
\hline 34 & 15SJ-61-Q3-05 & Canfieldite & 6.42 & $b d$ & $b d$ & 15.42 & $b d$ \\
\hline 35 & 5SSJ-96-Q1 Line 00 & Canfieldite & 1.73 & $b d$ & $b d$ & 18.62 & $b d$ \\
\hline 36 & 5SSJ-96-Q1 Line 00 & Canfieldite & 1.67 & $b d$ & bd & 18.12 & bd \\
\hline 37 & 5SSJ-96-Q1 Line 00؛ & Canfieldite & 2.59 & $b d$ & $b d$ & 17.73 & $b d$ \\
\hline 38 & 15SSJ-94-Q5-4 & Canfieldite & 0.02 & $b d$ & $b d$ & 21.29 & bd \\
\hline 39 & 15SSJ-95-Q2-1 & Canfieldite & 0.03 & $b d$ & $b d$ & 19.22 & bd \\
\hline
\end{tabular}

Abbreviations: bd-below the detection limit. 
2s and sulfosalts from the Shuangjianzishan Ag-Pb-Zn deposit (wt \%)

\begin{tabular}{|c|c|c|c|c|c|c|c|c|}
\hline $\mathrm{Cu}$ & $\mathrm{Fe}$ & Co & $\mathrm{Ni}$ & $\mathrm{Au}$ & $\mathrm{Ag}$ & $\mathrm{Cd}$ & $\mathrm{Te}$ & $\mathrm{Sn}$ \\
\hline 0.02 & $b d$ & 0.01 & 0.02 & $b d$ & bd & 0.10 & 0.02 & 0.03 \\
\hline bd & 0.01 & bd & bd & bd & bd & 0.18 & 0.03 & bd \\
\hline 0.07 & 0.12 & bd & 0.04 & 0.11 & 0.07 & bd & 0.04 & bd \\
\hline 0.08 & 12.77 & 0.06 & 0.03 & bd & bd & 0.13 & 0.01 & bd \\
\hline 0.86 & 16.12 & bd & bd & 0.02 & 0.01 & 0.05 & bd & 0.09 \\
\hline 0.03 & 59.45 & 0.08 & bd & 0.07 & bd & bd & 0.01 & bd \\
\hline bd & 59.23 & 0.08 & bd & 0.01 & bd & 0.01 & bd & bd \\
\hline 0.01 & 59.64 & 0.06 & bd & 0.02 & 0.02 & bd & bd & bd \\
\hline 34.76 & 30.07 & 0.02 & bd & 0.01 & 0.07 & 0.01 & 0.01 & 0.29 \\
\hline 34.62 & 30.02 & 0.03 & bd & bd & 0.07 & 0.01 & bd & bd \\
\hline 0.03 & bd & 0.01 & bd & bd & 58.89 & 2.12 & bd & $b d$ \\
\hline 0.20 & 0.02 & bd & bd & bd & 59.15 & 2.06 & bd & bd \\
\hline 0.74 & 0.09 & bd & 0.05 & 0.04 & 63.52 & bd & bd & bd \\
\hline 0.56 & $b d$ & bd & bd & 0.01 & 58.19 & bd & bd & bd \\
\hline 0.65 & bd & bd & 0.02 & bd & 65.99 & bd & bd & bd \\
\hline 1.20 & 0.03 & 0.01 & bd & bd & 76.09 & 2.67 & bd & bd \\
\hline 1.18 & 0.20 & 0.01 & bd & bd & 75.74 & 3.16 & bd & bd \\
\hline 1.56 & bd & bd & 0.02 & 0.05 & 72.39 & 1.19 & bd & bd \\
\hline 1.25 & bd & 0.02 & bd & bd & 69.99 & 1.29 & bd & bd \\
\hline 13.43 & 2.13 & 0.03 & bd & bd & 38.41 & 1.07 & bd & bd \\
\hline 11.88 & 1.67 & bd & bd & bd & 38.53 & 1.35 & bd & bd \\
\hline 23.39 & 5.10 & 0.02 & bd & bd & 21.75 & 0.01 & bd & bd \\
\hline 18.64 & 4.73 & bd & bd & bd & 22.46 & 4.29 & bd & bd \\
\hline 19.59 & 5.07 & 0.01 & bd & bd & 24.33 & 0.96 & bd & bd \\
\hline 21.72 & 4.41 & bd & bd & bd & 23.58 & 0.78 & bd & bd \\
\hline 21.68 & 4.50 & 0.01 & bd & bd & 23.90 & 0.01 & bd & bd \\
\hline 2.21 & 0.09 & bd & 0.01 & bd & 70.45 & 2.57 & bd & bd \\
\hline 1.74 & bd & bd & 0.02 & 0.04 & 70.21 & 2.59 & bd & bd \\
\hline 1.48 & 0.01 & bd & bd & bd & 71.07 & 2.64 & bd & bd \\
\hline 1.39 & 0.01 & bd & 0.01 & bd & 75.10 & 2.55 & bd & bd \\
\hline bd & 0.02 & 0.02 & 0.03 & 0.03 & 66.46 & 0.01 & 0.21 & 11.49 \\
\hline bd & bd & 0.02 & 0.03 & bd & 64.26 & 2.15 & 0.15 & 12.04 \\
\hline bd & bd & bd & 0.02 & bd & 63.46 & 2.26 & 0.46 & 13.38 \\
\hline bd & $b d$ & bd & bd & bd & 62.76 & 1.64 & 0.47 & 13.27 \\
\hline 0.15 & 0.03 & 0.01 & bd & bd & 63.44 & 2.03 & 0.17 & 14.23 \\
\hline 0.10 & bd & bd & 0.05 & 0.03 & 64.63 & 0.25 & 0.43 & 13.76 \\
\hline 0.12 & bd & bd & 0.02 & bd & 64.42 & 0.27 & 0.16 & 14.33 \\
\hline 0.81 & 0.21 & 0.01 & 0.02 & bd & 61.39 & 1.03 & 0.37 & 14.96 \\
\hline 4.94 & 0.14 & bd & bd & bd & 60.38 & 0.26 & 0.39 & 13.80 \\
\hline
\end{tabular}




\begin{tabular}{|c|c|}
\hline $\mathrm{Pb}$ & Total \\
\hline 85.91 & 99.43 \\
\hline 85.67 & 99.06 \\
\hline 85.46 & 99.43 \\
\hline bd & 99.32 \\
\hline$b d$ & 99.10 \\
\hline bd & 99.36 \\
\hline bd & 99.07 \\
\hline$b d$ & 99.92 \\
\hline$b d$ & 99.80 \\
\hline$b d$ & 99.29 \\
\hline$b d$ & 99.71 \\
\hline$b d$ & 100.49 \\
\hline 0.11 & 100.25 \\
\hline bd & 100.18 \\
\hline 0.21 & 100.98 \\
\hline$b d$ & 100.83 \\
\hline$b d$ & 99.41 \\
\hline$b d$ & 100.51 \\
\hline$b d$ & 99.09 \\
\hline$b d$ & 100.97 \\
\hline$b d$ & 99.02 \\
\hline bd & 99.94 \\
\hline$b d$ & 99.12 \\
\hline bd & 99.03 \\
\hline$b d$ & 99.64 \\
\hline$b d$ & 99.25 \\
\hline bd & 100.57 \\
\hline$b d$ & 100.19 \\
\hline$b d$ & 100.08 \\
\hline$b d$ & 100.09 \\
\hline$b d$ & 99.42 \\
\hline bd & 100.25 \\
\hline$b d$ & 100.77 \\
\hline bd & 99.99 \\
\hline$b d$ & 100.42 \\
\hline$b d$ & 99.04 \\
\hline bd & 99.64 \\
\hline$b d$ & 100.09 \\
\hline bd & 99.15 \\
\hline
\end{tabular}


Table A2 LA-ICP-MS zircon U-Pb isotop

\begin{tabular}{|c|c|c|c|c|c|c|}
\hline \multirow[t]{2}{*}{ Samples } & \multirow[b]{2}{*}{${ }^{207} \mathrm{~Pb} /{ }^{206} \mathrm{~Pb}$} & \multirow[b]{2}{*}{ 1s } & \multicolumn{4}{|c|}{ Isotopic ratios } \\
\hline & & & ${ }^{207} \mathrm{~Pb} / /^{235} \mathrm{U}$ & $1 \mathrm{~s}$ & ${ }^{206} \mathrm{~Pb} /{ }^{238} \mathrm{U}$ & 1s \\
\hline \multicolumn{7}{|l|}{$17 S J-24$} \\
\hline 17SJ-24-2 & 0.0554 & 0.0034 & 0.3046 & 0.0196 & 0.0396 & 0.0007 \\
\hline $17 \mathrm{SJ}-24-4$ & 0.0501 & 0.0079 & 0.2846 & 0.0532 & 0.0400 & 0.0017 \\
\hline $17 \mathrm{SJ}-24-5$ & 0.0555 & 0.0030 & 0.3056 & 0.0158 & 0.0400 & 0.0009 \\
\hline $17 \mathrm{SJ}-24-9$ & 0.0502 & 0.0029 & 0.2716 & 0.0147 & 0.0392 & 0.0005 \\
\hline $17 \mathrm{SJ}-24-10$ & 0.0496 & 0.0025 & 0.2740 & 0.0138 & 0.0396 & 0.0005 \\
\hline $17 \mathrm{SJ}-24-11$ & 0.0571 & 0.0034 & 0.3142 & 0.0170 & 0.0402 & 0.0005 \\
\hline $17 \mathrm{SJ}-24-12$ & 0.0505 & 0.0035 & 0.2776 & 0.0185 & 0.0395 & 0.0007 \\
\hline $17 \mathrm{SJ}-24-13$ & 0.0564 & 0.0057 & 0.3095 & 0.0295 & 0.0402 & 0.0011 \\
\hline 17SJ-24-14 & 0.0613 & 0.0126 & 0.3221 & 0.0442 & 0.0392 & 0.0029 \\
\hline $17 \mathrm{SJ}-24-15$ & 0.0612 & 0.0077 & 0.3325 & 0.0353 & 0.0399 & 0.0009 \\
\hline $17 \mathrm{SJ}-24-16$ & 0.0561 & 0.0076 & 0.3098 & 0.0393 & 0.0408 & 0.0018 \\
\hline $17 \mathrm{SJ}-24-17$ & 0.0549 & 0.0048 & 0.3034 & 0.0281 & 0.0393 & 0.0008 \\
\hline $17 \mathrm{SJ}-24-18$ & 0.0574 & 0.0043 & 0.3217 & 0.0247 & 0.0404 & 0.0008 \\
\hline $17 \mathrm{SJ}-24-21$ & 0.0559 & 0.0045 & 0.3008 & 0.0221 & 0.0391 & 0.0008 \\
\hline $17 \mathrm{SJ}-24-22$ & 0.0553 & 0.0037 & 0.2958 & 0.0188 & 0.0392 & 0.0007 \\
\hline $17 \mathrm{SJ}-24-24$ & 0.0571 & 0.0032 & 0.3092 & 0.0172 & 0.0393 & 0.0006 \\
\hline $17 \mathrm{SJ}-24-25$ & 0.0564 & 0.0029 & 0.3057 & 0.0149 & 0.0394 & 0.0006 \\
\hline $17 \mathrm{SJ}-24-28$ & 0.0543 & 0.0032 & 0.2918 & 0.0166 & 0.0396 & 0.0007 \\
\hline $17 \mathrm{SJ}-24-29$ & 0.0540 & 0.0033 & 0.2911 & 0.0170 & 0.0393 & 0.0006 \\
\hline \multicolumn{7}{|l|}{$17 S J-60$} \\
\hline 17SJ-60-1 & 0.0499 & 0.0045 & 0.1441 & 0.0116 & 0.0212 & 0.0005 \\
\hline $17 \mathrm{SJ}-60-2$ & 0.0538 & 0.0061 & 0.1476 & 0.0168 & 0.0201 & 0.0005 \\
\hline $17 \mathrm{SJ}-60-4$ & 0.0483 & 0.0033 & 0.1413 & 0.0090 & 0.0212 & 0.0005 \\
\hline $17 \mathrm{SJ}-60-5$ & 0.0483 & 0.0058 & 0.1393 & 0.0156 & 0.0208 & 0.0007 \\
\hline $17 \mathrm{SJ}-60-6$ & 0.0489 & 0.0047 & 0.1411 & 0.0117 & 0.0213 & 0.0005 \\
\hline $17 \mathrm{SJ}-60-7$ & 0.0498 & 0.0041 & 0.1455 & 0.0115 & 0.0212 & 0.0004 \\
\hline 17SJ-60-8 & 0.0489 & 0.0049 & 0.1427 & 0.0134 & 0.0212 & 0.0005 \\
\hline $17 \mathrm{SJ}-60-9$ & 0.0508 & 0.0037 & 0.1465 & 0.0105 & 0.0210 & 0.0004 \\
\hline $17 \mathrm{SJ}-60-10$ & 0.0493 & 0.0054 & 0.1388 & 0.0134 & 0.0212 & 0.0005 \\
\hline $17 \mathrm{SJ}-60-11$ & 0.0488 & 0.0096 & 0.1363 & 0.0255 & 0.0213 & 0.0007 \\
\hline $17 \mathrm{SJ}-60-12$ & 0.0541 & 0.0051 & 0.1531 & 0.0129 & 0.0208 & 0.0005 \\
\hline $17 \mathrm{SJ}-60-14$ & 0.0500 & 0.0098 & 0.1460 & 0.0290 & 0.0211 & 0.0012 \\
\hline $17 \mathrm{SJ}-60-16$ & 0.0485 & 0.0049 & 0.1422 & 0.0143 & 0.0211 & 0.0006 \\
\hline 17SJ-60-18 & 0.0492 & 0.0027 & 0.1411 & 0.0069 & 0.0212 & 0.0004 \\
\hline $17 \mathrm{SJ}-60-19$ & 0.0480 & 0.0060 & 0.1333 & 0.0140 & 0.0206 & 0.0006 \\
\hline $17 \mathrm{SJ}-60-20$ & 0.0486 & 0.0034 & 0.1403 & 0.0093 & 0.0212 & 0.0004 \\
\hline $17 \mathrm{SJ}-60-21$ & 0.0489 & 0.0071 & 0.1345 & 0.0157 & 0.0211 & 0.0007 \\
\hline $17 \mathrm{SJ}-60-22$ & 0.0490 & 0.0037 & 0.1369 & 0.0091 & 0.0204 & 0.0004 \\
\hline $17 \mathrm{SJ}-60-23$ & 0.0484 & 0.0037 & 0.1418 & 0.0110 & 0.0211 & 0.0005 \\
\hline $17 \mathrm{SJ}-60-24$ & 0.0489 & 0.0046 & 0.1421 & 0.0108 & 0.0212 & 0.0007 \\
\hline $17 \mathrm{SJ}-60-25$ & 0.0489 & 0.0052 & 0.1435 & 0.0133 & 0.0212 & 0.0008 \\
\hline \multicolumn{7}{|l|}{ 17SJ-87 } \\
\hline 17SJ-87-1 & 0.0473 & 0.0052 & 0.1362 & 0.0140 & 0.0210 & 0.0005 \\
\hline 17SJ-87-2 & 0.0520 & 0.0219 & 0.1401 & 0.0443 & 0.0207 & 0.0025 \\
\hline $17 \mathrm{SJ}-87-3$ & 0.0533 & 0.0026 & 0.1540 & 0.0069 & 0.0211 & 0.0004 \\
\hline $17 \mathrm{SJ}-87-4$ & 0.0511 & 0.0132 & 0.1476 & 0.0347 & 0.0212 & 0.0010 \\
\hline $17 \mathrm{SJ}-87-5$ & 0.0520 & 0.0023 & 0.1532 & 0.0066 & 0.0213 & 0.0003 \\
\hline $17 \mathrm{SJ}-87-7$ & 0.0495 & 0.0043 & 0.1435 & 0.0114 & 0.0213 & 0.0005 \\
\hline $17 \mathrm{SJ}-87-8$ & 0.0662 & 0.0261 & 0.1570 & 0.0282 & 0.0212 & 0.0014 \\
\hline $17 \mathrm{SJ}-87-9$ & 0.0541 & 0.0541 & 0.1434 & 0.0000 & 0.0213 & 0.0022 \\
\hline $17 \mathrm{SJ}-87-11$ & 0.0528 & 0.0036 & 0.1552 & 0.0108 & 0.0213 & 0.0004 \\
\hline $17 \mathrm{SJ}-87-12$ & 0.0501 & 0.0034 & 0.1449 & 0.0092 & 0.0212 & 0.0004 \\
\hline
\end{tabular}




\begin{tabular}{|c|c|c|c|c|c|c|}
\hline $17 \mathrm{SJ}-87-13$ & 0.0481 & 0.0042 & 0.1395 & 0.0117 & 0.0213 & 0.0006 \\
\hline $17 \mathrm{SJ}-87-14$ & 0.0518 & 0.0048 & 0.1531 & 0.0155 & 0.0213 & 0.0007 \\
\hline $17 \mathrm{SJ}-87-15$ & 0.0507 & 0.0047 & 0.1485 & 0.0142 & 0.0212 & 0.0007 \\
\hline 17SJ-87-16 & 0.0496 & 0.0021 & 0.1440 & 0.0062 & 0.0212 & 0.0003 \\
\hline $17 \mathrm{SJ}-87-17$ & 0.0500 & 0.0090 & 0.1436 & 0.0228 & 0.0213 & 0.0009 \\
\hline $17 \mathrm{SJ}-87-18$ & 0.0502 & 0.0041 & 0.1459 & 0.0113 & 0.0211 & 0.0004 \\
\hline $17 \mathrm{SJ}-87-20$ & 0.0497 & 0.0042 & 0.1443 & 0.0112 & 0.0214 & 0.0005 \\
\hline $17 \mathrm{SJ}-87-22$ & 0.0464 & 0.0030 & 0.1326 & 0.0080 & 0.0209 & 0.0004 \\
\hline $17 \mathrm{SJ}-87-23$ & 0.0503 & 0.0062 & 0.1482 & 0.0204 & 0.0212 & 0.0006 \\
\hline 17SJ-87-24 & 0.0484 & 0.0085 & 0.1411 & 0.0231 & 0.0212 & 0.0008 \\
\hline \multicolumn{7}{|l|}{ 17SJ-53 } \\
\hline $17 \mathrm{SJ}-53-1$ & 0.0509 & 0.0025 & 0.1492 & 0.0074 & 0.0212 & 0.0003 \\
\hline $17 \mathrm{SJ}-53-1$ & 0.0516 & 0.0016 & 0.1512 & 0.0047 & 0.0211 & 0.0004 \\
\hline $17 \mathrm{SJ}-53-4$ & 0.0492 & 0.0039 & 0.1429 & 0.0105 & 0.0211 & 0.0005 \\
\hline 17SJ-53-5 & 0.0492 & 0.0022 & 0.1451 & 0.0066 & 0.0212 & 0.0005 \\
\hline 17SJ-53-6 & 0.0484 & 0.0015 & 0.1418 & 0.0044 & 0.0209 & 0.0003 \\
\hline $17 \mathrm{SJ}-53-9$ & 0.0488 & 0.0054 & 0.1397 & 0.0150 & 0.0211 & 0.0007 \\
\hline $17 \mathrm{SJ}-53-10$ & 0.0540 & 0.0025 & 0.1570 & 0.0071 & 0.0211 & 0.0003 \\
\hline $17 \mathrm{SJ}-53-11$ & 0.0464 & 0.0042 & 0.1337 & 0.0112 & 0.0209 & 0.0004 \\
\hline $17 \mathrm{SJ}-53-12$ & 0.0494 & 0.0019 & 0.1441 & 0.0058 & 0.0211 & 0.0004 \\
\hline 17SJ-53-13 & 0.0516 & 0.0032 & 0.1506 & 0.0091 & 0.0211 & 0.0003 \\
\hline $17 \mathrm{SJ}-53-14$ & 0.0494 & 0.0022 & 0.1443 & 0.0064 & 0.0210 & 0.0003 \\
\hline $17 \mathrm{SJ}-53-16$ & 0.0487 & 0.0024 & 0.1442 & 0.0073 & 0.0212 & 0.0004 \\
\hline 17SJ-53-17 & 0.0526 & 0.0033 & 0.1518 & 0.0094 & 0.0211 & 0.0004 \\
\hline $17 \mathrm{SJ}-53-18$ & 0.0486 & 0.0018 & 0.1421 & 0.0053 & 0.0213 & 0.0004 \\
\hline 17SJ-53-19 & 0.0500 & 0.0035 & 0.1468 & 0.0109 & 0.0211 & 0.0004 \\
\hline $17 \mathrm{SJ}-53-20$ & 0.0495 & 0.0035 & 0.1446 & 0.0108 & 0.0211 & 0.0005 \\
\hline $17 \mathrm{SJ}-53-21$ & 0.0473 & 0.0039 & 0.1369 & 0.0110 & 0.0212 & 0.0005 \\
\hline $17 \mathrm{SJ}-53-22$ & 0.0545 & 0.0027 & 0.1586 & 0.0078 & 0.0210 & 0.0005 \\
\hline $17 \mathrm{SJ}-53-23$ & 0.0499 & 0.0030 & 0.1447 & 0.0081 & 0.0210 & 0.0005 \\
\hline $17 \mathrm{SJ}-53-24$ & 0.0499 & 0.0031 & 0.1465 & 0.0092 & 0.0212 & 0.0004 \\
\hline $17 \mathrm{SJ}-53-25$ & 0.0513 & 0.0017 & 0.1489 & 0.0054 & 0.0209 & 0.0003 \\
\hline \multicolumn{7}{|l|}{ 17SJ-59 } \\
\hline 17SJ-59-2 & 0.0493 & 0.0028 & 0.1417 & 0.0080 & 0.0208 & 0.0004 \\
\hline $17 \mathrm{SJ}-59-3$ & 0.0504 & 0.0026 & 0.1484 & 0.0075 & 0.0212 & 0.0003 \\
\hline 17SJ-59-4 & 0.0489 & 0.0034 & 0.1438 & 0.0101 & 0.0211 & 0.0004 \\
\hline 17SJ-59-6 & 0.0502 & 0.0029 & 0.1487 & 0.0093 & 0.0212 & 0.0004 \\
\hline $17 \mathrm{SJ}-59-7$ & 0.0492 & 0.0018 & 0.1434 & 0.0053 & 0.0210 & 0.0003 \\
\hline $17 \mathrm{SJ}-59-8$ & 0.0476 & 0.0017 & 0.1389 & 0.0049 & 0.0209 & 0.0003 \\
\hline $17 \mathrm{SJ}-59-9$ & 0.0504 & 0.0040 & 0.1455 & 0.0099 & 0.0211 & 0.0004 \\
\hline $17 \mathrm{SJ}-59-10$ & 0.0511 & 0.0086 & 0.1532 & 0.0180 & 0.0212 & 0.0006 \\
\hline $17 \mathrm{SJ}-59-11$ & 0.0464 & 0.0023 & 0.1340 & 0.0064 & 0.0208 & 0.0003 \\
\hline 17SJ-59-12 & 0.0496 & 0.0019 & 0.1471 & 0.0060 & 0.0212 & 0.0003 \\
\hline $17 \mathrm{SJ}-59-13$ & 0.0489 & 0.0030 & 0.1435 & 0.0092 & 0.0209 & 0.0004 \\
\hline $17 \mathrm{SJ}-59-14$ & 0.0485 & 0.0025 & 0.1423 & 0.0073 & 0.0212 & 0.0003 \\
\hline 17SJ-59-15 & 0.0500 & 0.0023 & 0.1467 & 0.0069 & 0.0211 & 0.0004 \\
\hline 17SJ-59-16 & 0.0486 & 0.0022 & 0.1411 & 0.0063 & 0.0211 & 0.0004 \\
\hline 17SJ-59-17 & 0.0510 & 0.0024 & 0.1499 & 0.0071 & 0.0213 & 0.0003 \\
\hline 17SJ-59-18 & 0.0485 & 0.0026 & 0.1387 & 0.0069 & 0.0209 & 0.0004 \\
\hline 17SJ-59-19 & 0.0470 & 0.0064 & 0.1354 & 0.0166 & 0.0212 & 0.0009 \\
\hline $17 \mathrm{SJ}-59-21$ & 0.0528 & 0.0040 & 0.1555 & 0.0106 & 0.0215 & 0.0005 \\
\hline 17SJ-59-22 & 0.0490 & 0.0014 & 0.1428 & 0.0043 & 0.0210 & 0.0002 \\
\hline $17 \mathrm{SJ}-59-24$ & 0.0477 & 0.0059 & 0.1378 & 0.0169 & 0.0208 & 0.0006 \\
\hline $17 \mathrm{SJ}-59-25$ & 0.0536 & 0.0019 & 0.1551 & 0.0056 & 0.0210 & 0.0003 \\
\hline
\end{tabular}


ic data of various igneous rocks from the Shuangjianzishan deposit

\begin{tabular}{|c|c|c|c|c|c|c|c|}
\hline \multirow[b]{2}{*}{${ }^{208} \mathrm{~Pb} /{ }^{232} \mathrm{Th}$} & \multirow[b]{2}{*}{$1 \mathrm{~s}$} & \multirow[b]{2}{*}{${ }^{207} \mathrm{~Pb} /{ }^{206} \mathrm{~Pb}$} & \multirow[b]{2}{*}{$1 \mathrm{~s}$} & \multicolumn{4}{|c|}{ Ages (Ma) } \\
\hline & & & & ${ }^{207} \mathrm{~Pb} /{ }^{235} \mathrm{U}$ & $1 \mathrm{~s}$ & ${ }^{206} \mathrm{~Pb} /{ }^{238} \mathrm{U}$ & $1 \mathrm{~s}$ \\
\hline 0.0149 & 0.0006 & 428 & 137.0 & 270 & 15.2 & 251 & 4.4 \\
\hline 0.0141 & 0.0007 & 198 & 330 & 254 & 42.1 & 253 & 10.7 \\
\hline 0.0137 & 0.0006 & 432 & 119 & 271 & 12.3 & 253 & 5.3 \\
\hline 0.0119 & 0.0004 & 206 & 133 & 244 & 11.7 & 248 & 3.4 \\
\hline 0.0132 & 0.0004 & 189 & 121 & 246 & 11.0 & 250 & 3.4 \\
\hline 0.0142 & 0.0005 & 494 & 126 & 277 & 13.1 & 254 & 3.3 \\
\hline 0.0134 & 0.0005 & 220 & 158 & 249 & 14.7 & 250 & 4.3 \\
\hline 0.0170 & 0.0009 & 478 & 221 & 274 & 22.9 & 254 & 6.8 \\
\hline 0.0148 & 0.0013 & 650 & 454 & 284 & 34.0 & 248 & 18.0 \\
\hline 0.0161 & 0.0009 & 656 & 273 & 291 & 26.9 & 253 & 5.8 \\
\hline 0.0133 & 0.0013 & 457 & 304 & 274 & 30.4 & 258 & 10.9 \\
\hline 0.0130 & 0.0009 & 409 & 190 & 269 & 21.9 & 248 & 4.7 \\
\hline 0.0131 & 0.0007 & 506 & 167 & 283 & 19.0 & 256 & 4.9 \\
\hline 0.0126 & 0.0006 & 456 & 180 & 267 & 17.2 & 247 & 4.8 \\
\hline 0.0138 & 0.0006 & 433 & 151.8 & 263 & 14.7 & 248 & 4.3 \\
\hline 0.0127 & 0.0004 & 494 & 124 & 274 & 13.3 & 249 & 3.6 \\
\hline 0.0138 & 0.0005 & 478 & 113.0 & 271 & 11.6 & 249 & 3.7 \\
\hline 0.0136 & 0.0005 & 389 & 133 & 260 & 13.0 & 250 & 4.1 \\
\hline 0.0135 & 0.0005 & 372 & 136 & 259 & 13.4 & 248 & 3.7 \\
\hline 0.0070 & 0.0004 & 191 & 196.3 & 137 & 10.3 & 135 & 2.9 \\
\hline 0.0059 & 0.0003 & 361 & 255.5 & 140 & 14.8 & 128 & 3.0 \\
\hline 0.0075 & 0.0004 & 122 & 211.1 & 134 & 8.0 & 135 & 3.0 \\
\hline 0.0069 & 0.0005 & 117 & 272.2 & 132 & 13.9 & 133 & 4.2 \\
\hline 0.0071 & 0.0004 & 139 & 211.1 & 134 & 10.4 & 136 & 3.1 \\
\hline 0.0070 & 0.0003 & 183 & 181.5 & 138 & 10.2 & 135 & 2.8 \\
\hline 0.0077 & 0.0004 & 142.7 & 222.2 & 135 & 11.9 & 135 & 3.2 \\
\hline 0.0064 & 0.0002 & 232 & 168.5 & 139 & 9.3 & 134 & 2.8 \\
\hline 0.0076 & 0.0004 & 161 & 237.0 & 132 & 12.0 & 135 & 3.3 \\
\hline 0.0069 & 0.0005 & 139 & 407.4 & 130 & 22.8 & 136 & 4.5 \\
\hline 0.0073 & 0.0004 & 376 & 214.8 & 145 & 11.4 & 133 & 3.4 \\
\hline 0.0066 & 0.0007 & 195 & 399.9 & 138 & 25.7 & 135 & 7.3 \\
\hline 0.0069 & 0.0003 & 124 & 222.2 & 135 & 12.7 & 135 & 3.6 \\
\hline 0.0065 & 0.0002 & 167 & 125.0 & 134 & 6.2 & 135 & 2.7 \\
\hline 0.0067 & 0.0004 & 102 & 270.3 & 127 & 12.5 & 132 & 3.6 \\
\hline 0.0070 & 0.0003 & 132 & 155.5 & 133 & 8.3 & 135 & 2.4 \\
\hline 0.0064 & 0.0005 & 142.7 & 311.1 & 128 & 14.1 & 135 & 4.3 \\
\hline 0.0064 & 0.0004 & 150 & 166.6 & 130 & 8.1 & 130 & 2.4 \\
\hline 0.0065 & 0.0003 & 120 & 166.6 & 135 & 9.8 & 135 & 2.9 \\
\hline 0.0074 & 0.0010 & 143 & 207.4 & 135 & 9.6 & 135 & 4.7 \\
\hline 0.0062 & 0.0005 & 143 & 233.3 & 136 & 11.8 & 135 & 5.1 \\
\hline 0.0069 & 0.0003 & 65 & 244 & 130 & 12.5 & 134 & 2.9 \\
\hline 0.0062 & 0.0011 & 287 & 752 & 133 & 39.5 & 132 & 15.8 \\
\hline 0.0073 & 0.0003 & 339 & 111.1 & 145 & 6.1 & 135 & 2.3 \\
\hline 0.0080 & 0.0008 & 256 & 494 & 140 & 30.7 & 135 & 6.3 \\
\hline 0.0066 & 0.0002 & 287 & 99 & 145 & 5.8 & 136 & 1.9 \\
\hline 0.0064 & 0.0003 & 172 & 193 & 136 & 10.1 & 136 & 2.9 \\
\hline 0.0080 & 0.0021 & 813 & 660 & 148 & 24.8 & 135 & 9.0 \\
\hline 0.0120 & 0.0044 & 376 & 1396 & 136 & 0.1 & 136 & 14.1 \\
\hline 0.0067 & 0.0002 & 320 & 156 & 146 & 9.5 & 136 & 2.8 \\
\hline 0.0067 & 0.0003 & 198 & 159 & 137 & 8.1 & 135 & 2.5 \\
\hline
\end{tabular}




\begin{tabular}{|c|c|c|c|c|c|c|c|}
\hline 0.0072 & 0.0004 & 102 & 196 & 133 & 10.5 & 136 & 4.0 \\
\hline 0.0071 & 0.0006 & 276 & 213 & 145 & 13.6 & 136 & 4.6 \\
\hline 0.0070 & 0.0006 & 228 & 200 & 141 & 12.6 & 135 & 4.6 \\
\hline 0.0073 & 0.0002 & 176 & 97.2 & 137 & 5.5 & 135 & 1.9 \\
\hline 0.0080 & 0.0006 & 198 & 370 & 136 & 20.2 & 136 & 5.6 \\
\hline 0.0070 & 0.0003 & 206 & -8 & 138 & 10.0 & 135 & 2.4 \\
\hline 0.0071 & 0.0003 & 189 & 176 & 137 & 9.9 & 137 & 3.0 \\
\hline 0.0067 & 0.0002 & 17 & 148 & 126 & 7.1 & 133 & 2.6 \\
\hline 0.0069 & 0.0004 & 209 & 263 & 140 & 18.0 & 135 & 3.6 \\
\hline 0.0073 & 0.0006 & 120.5 & 380 & 134 & 20.6 & 135 & 4.7 \\
\hline 0.0064 & 0.0002 & 235 & 112.0 & 141 & 6.5 & 135 & 2.1 \\
\hline 0.0073 & 0.0002 & 265 & 75.0 & 143 & 4.1 & 135 & 2.2 \\
\hline 0.0073 & 0.0004 & 167 & 164.8 & 136 & 9.4 & 134 & 3.1 \\
\hline 0.0068 & 0.0002 & 167 & 100.9 & 138 & 5.8 & 135 & 2.9 \\
\hline 0.0068 & 0.0002 & 120.5 & 75.9 & 135 & 3.9 & 133 & 1.8 \\
\hline 0.0068 & 0.0005 & 139 & 250.0 & 133 & 13.4 & 134 & 4.6 \\
\hline 0.0064 & 0.0002 & 372 & 106.5 & 148 & 6.3 & 134 & 2.0 \\
\hline 0.0071 & 0.0004 & 20 & 212.9 & 127 & 10.0 & 133 & 2.8 \\
\hline 0.0065 & 0.0002 & 169 & 90.7 & 137 & 5.1 & 134 & 2.4 \\
\hline 0.0075 & 0.0004 & 265 & 175.0 & 142 & 8.0 & 134 & 2.2 \\
\hline 0.0069 & 0.0002 & 165 & 101.8 & 137 & 5.7 & 134 & 1.9 \\
\hline 0.0067 & 0.0002 & 200 & 121.3 & 137 & 6.5 & 136 & 2.3 \\
\hline 0.0068 & 0.0003 & 322 & 144.4 & 143 & 8.2 & 134 & 2.4 \\
\hline 0.0073 & 0.0002 & 128 & 88.9 & 135 & 4.7 & 136 & 2.2 \\
\hline 0.0072 & 0.0003 & 195 & 158.3 & 139 & 9.6 & 135 & 2.6 \\
\hline 0.0074 & 0.0003 & 169 & 159.2 & 137 & 9.6 & 135 & 2.9 \\
\hline 0.0067 & 0.0005 & 65 & 190.7 & 130 & 9.8 & 135 & 2.9 \\
\hline 0.0077 & 0.0004 & 394 & 113.0 & 150 & 6.9 & 134 & 3.0 \\
\hline 0.0071 & 0.0003 & 191 & 142.6 & 137 & 7.2 & 134 & 3.2 \\
\hline 0.0081 & 0.0004 & 191 & 146.3 & 139 & 8.1 & 135 & 2.6 \\
\hline 0.0068 & 0.0002 & 254 & 77.8 & 141 & 4.7 & 133 & 1.8 \\
\hline 0.0069 & 0.0004 & 165 & 133.3 & 135 & 7.1 & 133 & 2.7 \\
\hline 0.0071 & 0.0003 & 217 & 115.7 & 140 & 6.6 & 135 & 2.0 \\
\hline 0.0071 & 0.0003 & 143 & 155.5 & 136 & 8.9 & 134 & 2.6 \\
\hline 0.0071 & 0.0003 & 206 & 139.8 & 141 & 8.2 & 135 & 2.5 \\
\hline 0.0066 & 0.0002 & 154 & 87.0 & 136 & 4.7 & 134 & 1.8 \\
\hline 0.0070 & 0.0002 & 80 & 81.5 & 132 & 4.4 & 133 & 1.7 \\
\hline 0.0065 & 0.0003 & 217 & 185.2 & 138 & 8.7 & 135 & 2.5 \\
\hline 0.0061 & 0.0005 & 256 & 338.9 & 145 & 15.8 & 135 & 4.0 \\
\hline 0.0068 & 0.0002 & 17 & 114.8 & 128 & 5.7 & 133 & 1.8 \\
\hline 0.0070 & 0.0002 & 176 & 92.6 & 139 & 5.3 & 135 & 1.9 \\
\hline 0.0065 & 0.0003 & 143 & 140.7 & 136 & 8.2 & 133 & 2.6 \\
\hline 0.0066 & 0.0002 & 124 & 118.5 & 135 & 6.5 & 135 & 2.0 \\
\hline 0.0072 & 0.0003 & 195 & 107.4 & 139 & 6.1 & 135 & 2.5 \\
\hline 0.0072 & 0.0003 & 128 & 105.5 & 134 & 5.6 & 135 & 2.7 \\
\hline 0.0073 & 0.0002 & 243 & 109.2 & 142 & 6.3 & 136 & 2.0 \\
\hline 0.0073 & 0.0003 & 124 & 131.5 & 132 & 6.2 & 133 & 2.4 \\
\hline 0.0084 & 0.0010 & 56 & 287.0 & 129 & 14.9 & 136 & 5.9 \\
\hline 0.0066 & 0.0003 & 320 & 172.2 & 147 & 9.3 & 137 & 2.9 \\
\hline 0.0067 & 0.0001 & 146 & 68.5 & 136 & 3.8 & 134 & 1.4 \\
\hline 0.0054 & 0.0003 & 87 & 279.6 & 131 & 15.1 & 133 & 3.8 \\
\hline 0.0067 & 0.0002 & 354 & 77.8 & 146 & 4.9 & 134 & 1.9 \\
\hline
\end{tabular}




\begin{tabular}{|c|c|}
\hline${ }^{208} \mathrm{~Pb} /{ }^{232} \mathrm{Th}$ & $1 \mathrm{~s}$ \\
\hline 299 & 12.8 \\
\hline 283 & 13.0 \\
\hline 275 & 11.4 \\
\hline 238 & 8.9 \\
\hline 265 & 8.7 \\
\hline 285 & 10.5 \\
\hline 269 & 9.3 \\
\hline 341 & 17.7 \\
\hline 297 & 26.4 \\
\hline 323 & 18.8 \\
\hline 267 & 25.9 \\
\hline 261 & 17.5 \\
\hline 264 & 14.3 \\
\hline 252 & 11.7 \\
\hline 277 & 11.0 \\
\hline 255 & 8.3 \\
\hline 277 & 9.3 \\
\hline 273 & 10.2 \\
\hline 271 & 9.2 \\
\hline 142 & 7.6 \\
\hline 120 & 5.2 \\
\hline 151 & 7.5 \\
\hline 139 & 9.2 \\
\hline 143 & 7.8 \\
\hline 141 & 6.9 \\
\hline 154 & 8.3 \\
\hline 129 & 4.5 \\
\hline 153 & 8.2 \\
\hline 139 & 10.0 \\
\hline 147 & 8.2 \\
\hline 133 & 14.6 \\
\hline 138 & 7.0 \\
\hline 132 & 3.4 \\
\hline 135 & 8.7 \\
\hline 140 & 5.6 \\
\hline 130 & 10.3 \\
\hline 129 & 7.6 \\
\hline 131 & 5.5 \\
\hline 148 & 19.5 \\
\hline 125 & 10.8 \\
\hline 140 & 5.2 \\
\hline 125 & 21.3 \\
\hline 147 & 5.5 \\
\hline 161 & 15.7 \\
\hline 134 & 3.8 \\
\hline 130 & 5.0 \\
\hline 161 & 42.5 \\
\hline 241 & 87.4 \\
\hline 134 & 4.5 \\
\hline 135 & 5.2 \\
\hline
\end{tabular}




\begin{tabular}{|c|c|}
\hline 145 & 8.4 \\
\hline 143 & 12.0 \\
\hline 140 & 11.3 \\
\hline 146 & 3.7 \\
\hline 161 & 11.7 \\
\hline 141 & 5.8 \\
\hline 143 & 6.3 \\
\hline 136 & 3.5 \\
\hline 140 & 7.7 \\
\hline 146 & 12.2 \\
\hline 129 & 3.9 \\
\hline 147 & 4.5 \\
\hline 147 & 9.0 \\
\hline 137 & 4.6 \\
\hline 136 & 3.2 \\
\hline 137 & 10.2 \\
\hline 128 & 4.9 \\
\hline 142 & 8.2 \\
\hline 131 & 4.3 \\
\hline 151 & 7.1 \\
\hline 138 & 3.6 \\
\hline 134 & 4.6 \\
\hline 137 & 5.4 \\
\hline 147 & 3.9 \\
\hline 144 & 5.3 \\
\hline 148 & 6.3 \\
\hline 135 & 9.3 \\
\hline 156 & 8.7 \\
\hline 143 & 6.3 \\
\hline 164 & 7.4 \\
\hline 136 & 3.9 \\
\hline 140 & 7.1 \\
\hline 142 & 5.2 \\
\hline 142 & 5.4 \\
\hline 143 & 6.0 \\
\hline 134 & 4.2 \\
\hline 141 & 4.4 \\
\hline 130 & 6.5 \\
\hline 122 & 11.0 \\
\hline 137 & 4.3 \\
\hline 140 & 4.7 \\
\hline 131 & 5.7 \\
\hline 132 & 4.7 \\
\hline 145 & 5.4 \\
\hline 145 & 5.1 \\
\hline 147 & 4.7 \\
\hline 148 & 5.4 \\
\hline 169 & 19.3 \\
\hline 134 & 5.8 \\
\hline 136 & 3.0 \\
\hline 109 & 6.3 \\
\hline 134 & 3.4 \\
\hline
\end{tabular}

